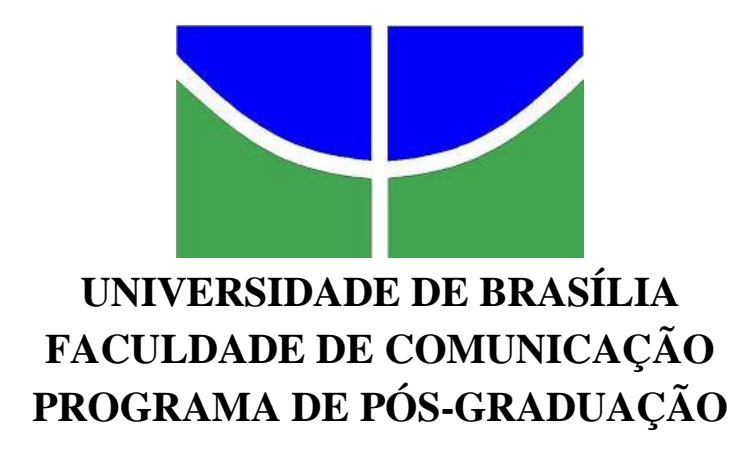

Dissertação de Mestrado

A CONSTRUÇÃo DAS RELAÇÕES DE GÊNERO NA PUBLICIDADE DA CERVEJA SKOL:

UMA ANÁLISE SOBRE CONSUMO, CULTURA E CRIATIVIDADE

Heloisa Helena de Sousa Franco Oliveira

Dezembro

2014 


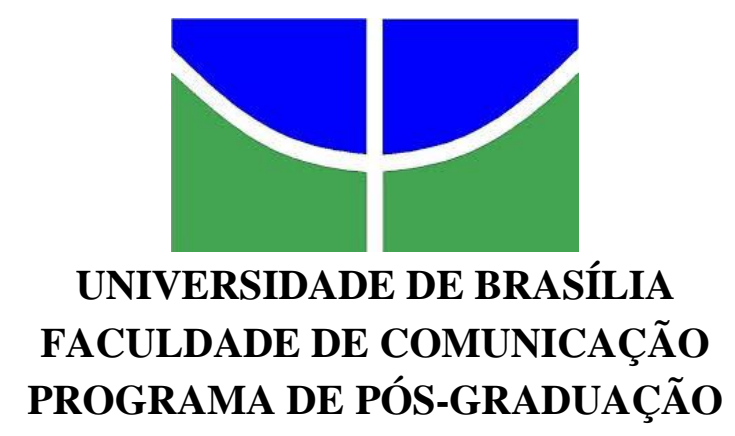

Dissertação de Mestrado

\section{A CONSTRUÇÃO DAS RELAÇÃOES DE GÊNERO NA PUBLICIDADE DA CERVEJA SKOL: \\ UMA ANÁLISE SOBRE CONSUMO, CULTURA E CRIATIVIDADE}

MESTRANDA: Heloisa Helena de Sousa Franco Oliveira

ORIENTADOR: Asdrúbal Borges Formiga Sobrinho

Linha de Pesquisa: Imagem e Som 


\section{A CONSTRUÇÃO DAS RELAÇÃOES DE GÊNERO NA PUBLICIDADE DA CERVEJA SKOL: \\ UMA ANÁLISE SOBRE PODER, CONSUMO, CULTURA E CRIATIVIDADE}

Brasília, dezembro de 2014

Dissertação aprovada pela Seguinte Banca Examinadora:

Prof. Dr. Asdrúbal Borges Formiga Sobrinho - Presidente

Universidade de Brasília
Profa. Dra. Liliane Maria Macedo Machado- Membro
Universidade de Brasília

Profa. Dra. Luiza Mônica Assis da Silva - Membro

Universidade Católica de Brasília

Profa. Dra. Elen Cristina Geraldes - Suplente

Universidade de Brasília 
Às mulheres de Queimadas 


\section{AGRADECIMENTOS}

Tenho muitos agradecimentos a fazer...

Primeiramente agradeço de todo o coração a Deus, a toda a espiritualidade, e a Maria, que me acompanharam neste processo de estudo e pesquisa.

À minha família, que permitiu o meu afastamento neste período, considerando a compreensão da minha filha e o desprendimento de minha mãe e de meu marido, que apoiaram Clara em minha ausência, com muito amor.

Ao meu companheiro Cristiano Oliveira, sempre amigo, presente e atuante como porto seguro em minha vida, nas idas e vindas do movimento que escolho fazer.

À minha filha Ana Clara por sua sensibilidade, confiança e grande amor.

À minha irmã Cynthya, que solidariamente acompanhou minhas angústias, escutou minhas preocupações e fez, o que sempre faz com todos os seres vivos que cruzam seu caminho, doou-se e cuidou de mim com muita dedicação e carinho.

Às minhas irmãs Gel e Pollyanna, pela companhia, pela força, por serem mães itinerantes e pelas lições que me ensinam diante da força com que enfrentam as dificuldades da vida.

À Melissa, que me fez e faz rir muito.

Ao meu pai, que mesmo doente nos ensinou a viver, a amar e a ter sensibilidade.

À minha mãe, que para mim é um exemplo a ser seguido de mulher. Agradeço por ter me ensinado a estudar e também sobre o poder de resistência.

Às minhas amigas queridas que tornam a vida cheia de significados, Paula, Suelyta, Dodora, Helena, Cida e Lili.

Às amigas que, além de lutarem comigo, ajudaram-me no apoio à realização dos grupos focais, emprestaram-me seus notebooks e ainda me deram carinho, ombro e atenção: Ana Laura e Nathaly.

À minha amiga-cunhada Lila, pela força diária, torcendo para que tudo desse certo.

Às minhas amigas de mestrado que me consolaram: Luma, Aline e Sanmya.

Aos professores do mestrado que me ensinaram tantas coisas que eu nem sei dizer: Martino, Elen Geraldes, Susana Dobal, Asdrúbal Borges, Tânia Montoro, Gustavo de Castro, Cláudia Busato, Selma Oliveira e a todos da disciplina de Seminário de Pesquisa da linha Imagem e Som.

Às professoras que compuseram a banca de qualificação deste trabalho, Elen Geraldes e Selma Oliveira.

Ao meu orientador, Asdrúbal Borges, pela orientação dedicada e sistemática, e pela profunda compreensão com minhas questões.

Aos participantes dos grupos focais que aceitaram participar da pesquisa.

$\mathrm{E}$ a todas as companheiras da Marcha Mundial das Mulheres 


\section{RESUMO}

Este trabalho apresenta uma análise da construção das relações de gênero na publicidade de cerveja, a partir dos filmes publicitários da marca de cerveja Skol veiculados na televisão aberta, nos últimos 17 anos. Os objetivos da nossa pesquisa foram analisar como homens e mulheres se identificam com os personagens construídos pela publicidade; identificar atualizações ou mudanças dos símbolos, gestos e textos presentes na publicidade de cerveja Skol, no que concerne à construção das relações de gênero; e verificar se houve inovação na abordagem das relações de gênero após as modificações na legislação e a partir das críticas advindas da sociedade. Como embasamento teórico, utilizamos os estudos culturais, de gênero e da criatividade para entender nosso objeto de pesquisa, isto porque foi possível, por meio dessa tríade, articular as visões que circulam e, aparentemente, partem do indivíduo, seja este publicitário ou receptor, tornam-se integrantes da cultura e estão presentes na publicidade. Para atingir nossos objetivos, a proposta metodológica aliou análise de conteúdo temática da linguagem das peças da marca Skol com a observação do cenário a partir de um estudo de recepção realizado com homens e mulheres, por meio da realização de grupos focais. Como resultados podemos constatar que: não houve inovação na abordagem das relações de gênero na publicidade de cerveja Skol dos últimos 17 anos, no entanto, houve mudanças na representação dos personagens; homens e mulheres se sentem influenciados pela publicidade ao associar cenários, como os exibidos nas peças publicitárias, ao consumo de cerveja e ao despertar neles a vontade de beber; as mulheres e os homens entre 21 e 43 anos, de classes média e menos favorecidas, envolvidos nos grupos focais desta pesquisa, não se identificam com os personagens apresentados nas peças, as mulheres como objeto de atração, e, os homens como bobos, eles, no entanto, dialogam com a perspectiva de masculinidade hegemônica apresentadas nos vídeos publicitários da Skol; ambos os gêneros acreditam haver identificação com as peças principalmente entre os mais jovens; homens e mulheres têm formas de consumo diferentes.

Palavras-chave: Comunicação. Publicidade. Estudos de Recepção. Relações de gênero. Consumo. Criatividade. 


\begin{abstract}
This work presents an analysis of the construction of gender relations in beer advertising, from Skol beer brand's commercials conveyed in broadcast television for the past 17 years. The objectives of our study were to analyze how men and women identify with the characters built by advertising; identify updates or changes of symbols, gestures and texts present in the Skol beer 's advertising, with regard to the construction of gender relations; and verify if there was innovation in the approach to gender relations after the modifications in legislation and from the criticism presented by society. As theoretical basis, we use cultural, gender and creativity studies to understand the research object, being possible, through this triad, to articulate the views circulating and apparently coming from the individual, be it advertising or receiver, views that become part of the culture and are present in advertising. To achieve our aims, the methodological proposal allied thematic content analysis of the language of the Skol brand's advertising parts through the observation the scene from a reception study of men and women, by performing focal groups. As a result we note that: there was no innovation in the approach of gender relations in Skol's beer advertising in the past 17 years, however, there have been changes in the representation of characters; men and women feel influenced by advertising to associate scenarios, as shown in the materials, with the consumption of beer, and to awaken in them the desire to drink; women and men between 21 and 43 years-old, from middle and lower classes, involved in the focal groups in this study, do not identify with the characters shown in parts of advertising, women as object of attraction, and men as futile, they, however, dialogue with the perspective of hegemonic masculinity presented in Skol's video commercials ; both genders believe there is identification with the parts especially among young people; men and women have different forms of consumption.
\end{abstract}

Keywords: Communication. Advertising. Reception Studies. Gender relations. Consumption. Creativity. 


\section{LISTA DE FIGURAS}

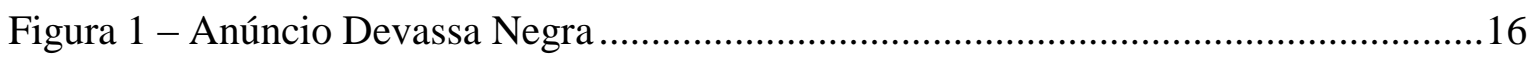

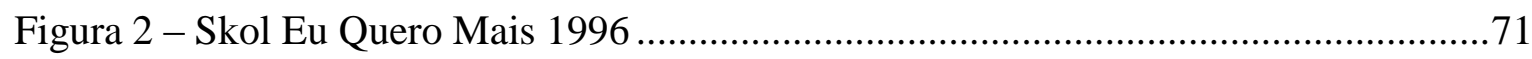

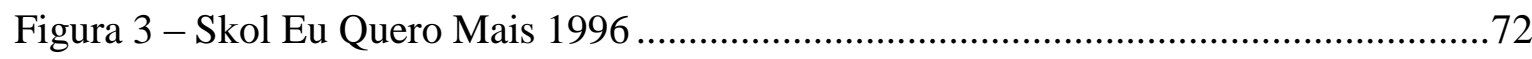

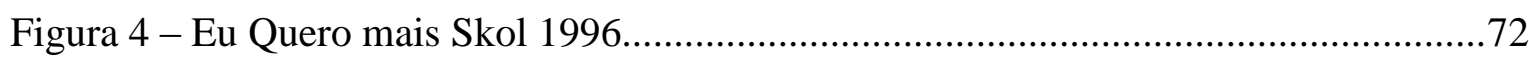

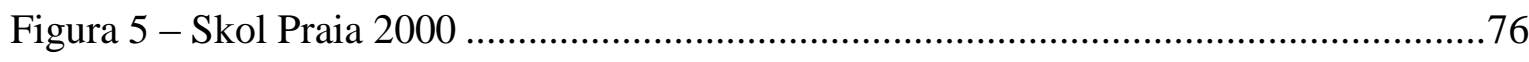

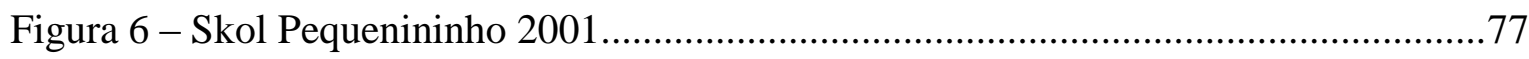

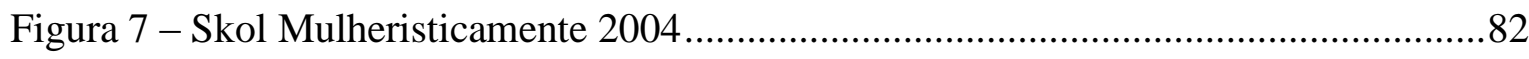

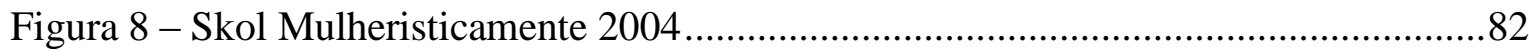

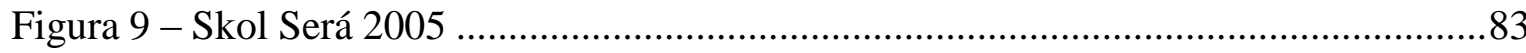

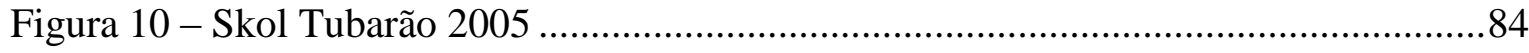

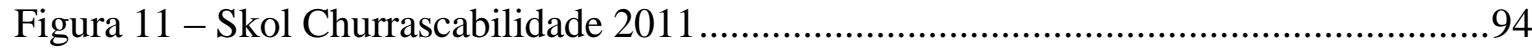

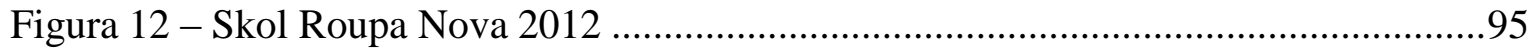

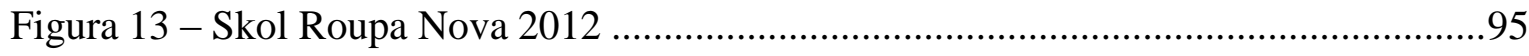

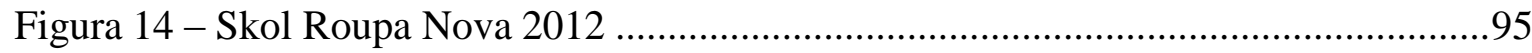

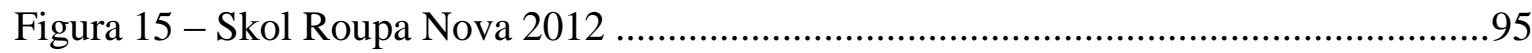

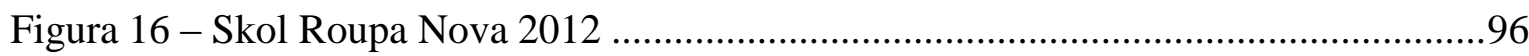

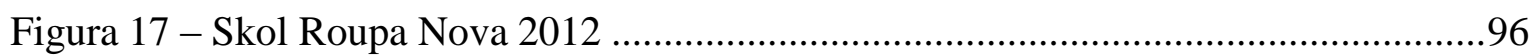




\section{LISTA DE TABELAS}

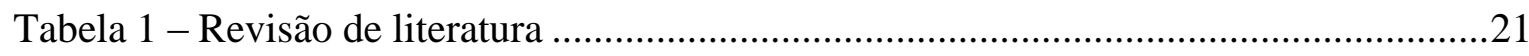

Tabela 2 - Revisão de literatura Estudos Culturais .............................................................33

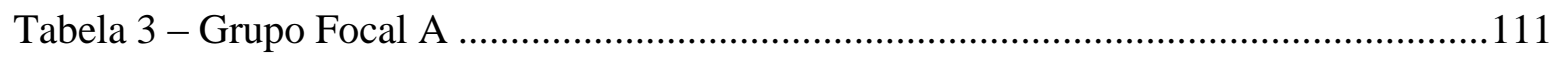

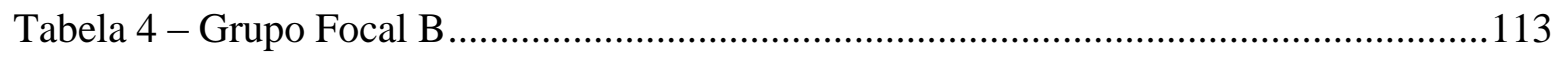

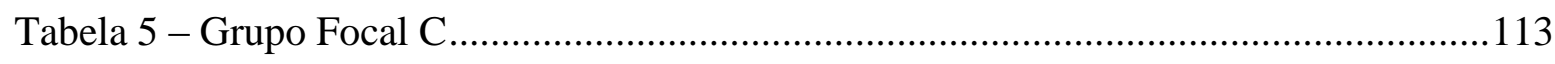




\section{SUMÁRIO}

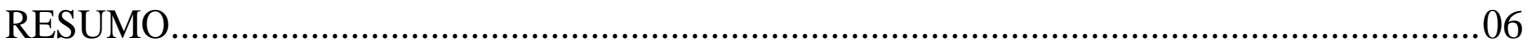

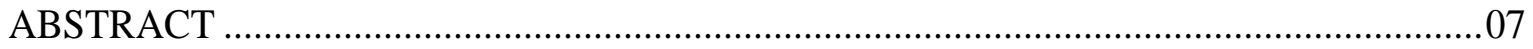

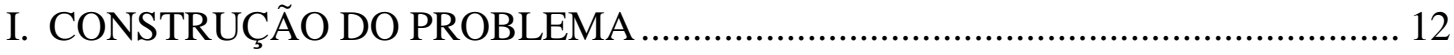

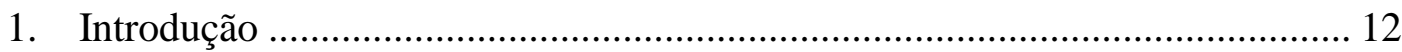

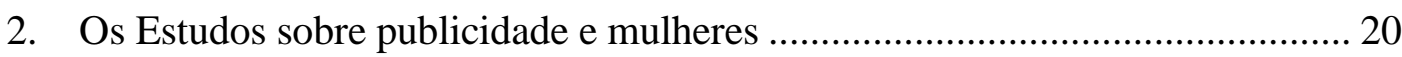

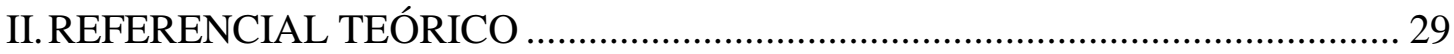

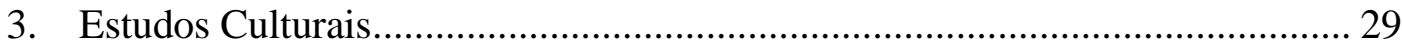

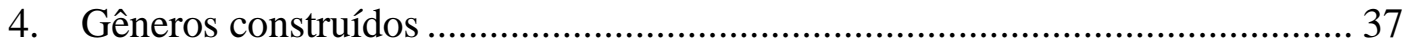

5. Publicidade: Discurso, linguagem e criatividade............................................ 46

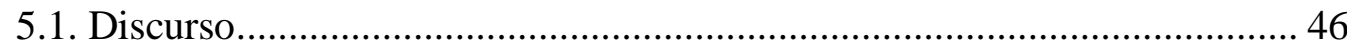

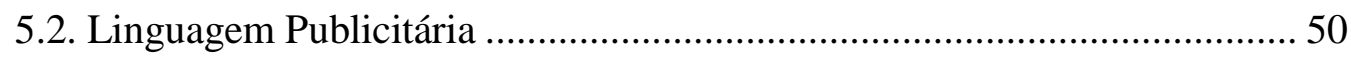

5.2.1. Construção das narrativas do cotidiano............................................ 53

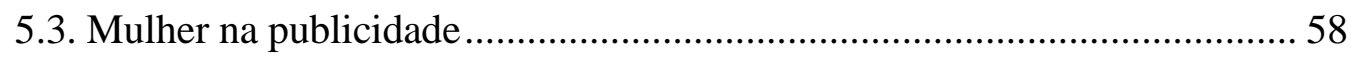

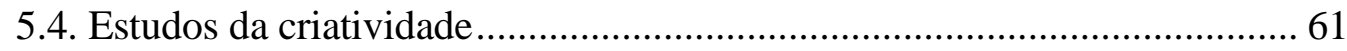

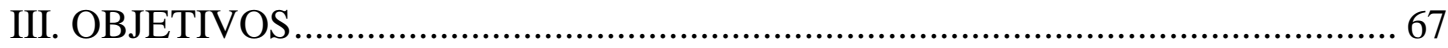

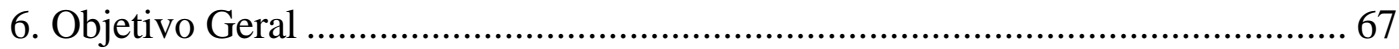

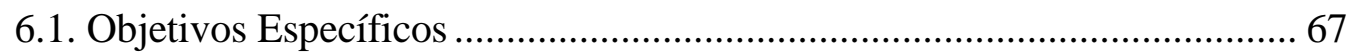

IV. PROCEDIMENTOS TEÓRICO-METODOLÓGICOS ....................................... 68

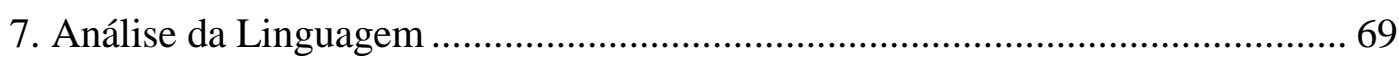

7.1. Roteiros dos vídeos publicitários......................................................... 71

7.2. Proposta de interpretação dos vídeos publicitários .................................... 105

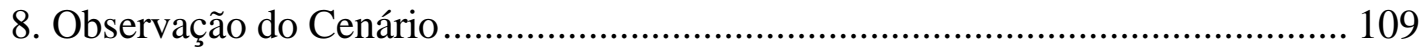

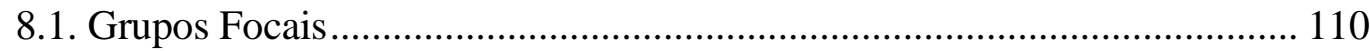

8.2. Peças Publicitárias - Cenários de Machismo e Felicidade ......................... 114

8.3. Personagens: Construção e Identificação .................................................... 119

8.4. Influência da publicidade e formas de consumo........................................ 122

8.5. Discussão grupos focais em comparação à proposta de interpretação dos vídeos publicitários................................................................................. 127

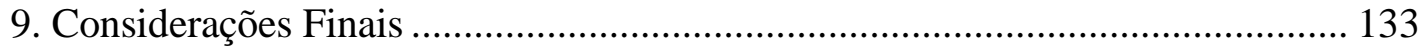

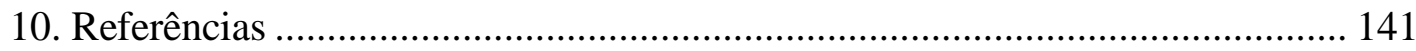

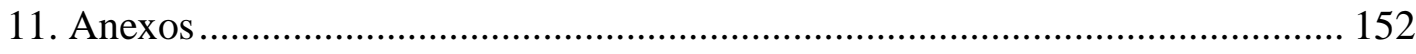




\section{CONSTRUÇÃO DO PROBLEMA}

\section{Introdução}

Não é exagero dizer que os objetos da Comunicação interferem na noção de cultura. A linguagem, os textos, a circulação de imagens e discursos emitidos pelos meios de comunicação de massa sem dúvida ajudam a construir o imaginário dos homens e mulheres que vivem na era contemporânea. Nossos objetos de estudo, os da Comunicação, são complexos e dinâmicos o que nos traz um desafio peculiar de compreender fenômenos comunicativos que não se localizam numa ponta ou na outra da comunicação, mas que podem estar tanto no processo, quanto no produto e no próprio ato de comunicar, expressar e informar. Além disso, o fenômeno comunicativo não pára no seu próprio processo, meio de comunicação, produto, continua a ecoar deixando rastros na cultura e no imaginário social, mudando a economia e construindo discursos acerca do ser, do estar e do sonhar. O fenômeno que nos une e nos torna sociáveis, o comunicar, pode ser abordado por várias dimensões e necessitar de várias disciplinas para compreendê-lo, mas o olhar e o foco na Comunicação, para os interessados em compreender e analisar seus fenômenos, a partir deles e em direção a eles, é o que nos diferencia de qualquer outra disciplina que tente entendê-los. Nesta dissertação, propomos analisar a abordagem das relações de gênero na publicidade de cerveja, o que, em princípio, pode parecer um tema simples e a priori esgotado. Muitos fatores e disciplinas como a Psicologia, a Sociologia, a Comunicação, a Antropologia e a Economia Política estão envolvidos com este objeto, tornando-o complexo, no entanto, o nosso movimento de partida e de chegada, nesta pesquisa, é a Comunicação, apesar de compreender o fenômeno estudado, baseado nas contribuições de todas estas disciplinas citadas, nós estamos decifrando as significações variáveis e diversas da mensagem publicitária, seja ela mesma com sua linguagem, ou como atividade profissional, que requer o uso constante da criatividade; seja ela ainda como elemento propulsor do sistema capitalista, do consumo, e revelador do estágio de sofisticação dos processos culturais por que passam a nossa sociedade e da construção do nosso imaginário.

As razões que nos levaram a escolha deste objeto de pesquisa foram várias. Peço licença para falar na primeira pessoa do singular apenas na exposição dos motivos que me levaram a escolher este tema, que são muito particulares e não me permitem escrever de outro modo. Várias questões me levaram a esta temática, uma delas é sem dúvida o fato de eu ser mulher, e também de perceber e viver as desigualdades nas 
relações de gênero na nossa sociedade. Esta percepção me levou a conhecer os movimentos sociais feministas e atuar neste campo de organização popular.

Os dados e a problemática da violência contra a mulher também foram e são fatores que me incomodam e me levam à reflexão e à constatação de que é necessário continuar a estudar as relações de gênero numa sociedade ainda marcada pelo machismo e patriarcado. Segundo o Censo Demográfico 2010, a maioria da população brasileira é composta por mulheres, mais de 97 milhões.

A razão de sexo, que consiste na relacão entre a quantidade de homens para cada grupo de 100 mulheres na populacão, foi de 96,0 no Brasil, em 2010, ou seja, havia 96,0 homens para cada 100 mulheres, indicando maioria de mulheres na populacão. (ESTATÍSTICA DE GÊNERO, 2014)

Dados recentes do Instituto Brasileiro de Geografia e Estatística (IBGE) baseados no Censo Demográfico de 2010 demonstraram que a desigualdade de gênero foi reduzida no acesso à educação e no processo educacional, e que também houve um aumento significativo de mulheres no mercado de trabalho, entre 2000 e 2010, passando de um nível de ocupacão de 35,4\% para 43,9\%. Ainda assim mantêm-se as desigualdades salariais em relação aos homens e em relação a alguns segmentos de mulheres como as brancas e as de raça negra ou parda.

A entrada das mulheres no mercado de trabalho não implica um processo natural que promoverá uma redefinicão de papéis na sociedade. Nos últimos 40 anos, a proporcão de mulheres em idade ativa ocupadas mais que dobrou; no entanto, a responsabilidade pelas atividades domésticas e de cuidados continua sendo uma atribuicão quase exclusivamente feminina. Segundo o Relatório anual socioeconômico da mulher 2013, da Secretaria de Políticas para as Mulheres, cerca de $90 \%$ das mulheres não economicamente ativas realizam afazeres domésticos e tem uma jornada média semanal de 34 horas, valor próximo do observado para as mulheres no mercado de trabalho (36,2 horas por semana) (BRASIL, 2013d). (ESTATÍSTICA DE GÊNERO, 2014)

A questão da jornada intensa de trabalho das mulheres também precisa ser levada em consideração, já que de acordo com dados do Instituto de Pesquisa Econômica Aplicada (Ipea) de 2012, 90\% das mulheres com mais de 16 anos realizam trabalho doméstico comparados a 50\% dos homens e que as mulheres gastam em média 10 horas semanais a mais que os homens com afazeres domésticos. Assim somadas as 
horas de trabalho das mulheres, elas trabalham 57 horas contra 53 dos homens, no entanto, eles trabalham sete horas a mais no mercado remunerado, enquanto as mulheres se ocupam mais com o trabalho não-remunerado, o que pode caracterizar menor poder aquisitivo para as mulheres, apesar do aumento do número delas na população economicamente ativa.

Já de acordo com dados da Vigilância de Violência e Acidentes (VIVA, 2009) do Ministério da Saúde, as mulheres são as maiores vítimas de violência desde a infância até a terceira idade. E segundo pesquisa feita pela Data Senado (2013), 13,5 milhões de mulheres já sofreram algum tipo de violência.

E por que eu estou de falando de violência? Porque este é um problema social onde as desigualdades de gênero se materializam, assim como é o caso do acesso ao mercado de trabalho e das diferenças salariais existentes entre homens e mulheres. No caso da violência contra as mulheres, a maior incidência acontece no ambiente doméstico, cerca de $71,8 \%$ dos assassinatos de mulheres acontecem dentro de suas casas, executadas pelos atuais ou ex-companheiros. Enquanto os homens tendem a ser vítimas de violência predominantemente nos espaços públicos, ou seja de violência urbana, o que demonstra uma diferença gritante nas formas de violência que atingem os gêneros. Segundo pesquisa realizada pelo Instituto Sangari, na qual foi construído o Mapa da Violência 2012, em 10 anos, de 1997 a 2007, foram assassinadas 41.532 mulheres, o que representa um índice de 4.2 mulheres assassinadas por 100.000 habitantes, apenas pelo fato de serem mulheres, ou seja, estamos falando em violência de gênero.

A Paraíba ocupa, neste mesmo Mapa da Violência 2012, o $7^{\circ}$ lugar em número de assassinatos de mulheres, e a capital, João Pessoa, é a $2^{\text {a }}$ cidade brasileira no ranking de feminicídios.

Lembro-me de um episódio, infelizmente de dor e violência, ter me conduzido à certeza de que a discussão de gênero não estava esgotada. $O$ estupro coletivo que aconteceu na cidade de Queimadas, no estado da Paraíba, evento durante o qual cinco mulheres foram estupradas por dez homens, no período do carnaval, durante um churrasco de comemoração do aniversário de um dos executantes do estupro coletivo, marcou-me profundamente. Relações de amizade se transformaram em violência. As mulheres foram convidadas para o que achavam que seria uma festa e foram feitas de cobaias sexuais. Duas mulheres foram assassinadas 
porque reconheceram os estupradores, já que eram todos "amigos". A justificativa para o crime foi "presentear" o aniversariante com um estupro coletivo. Visando despistar a autoria eles simularam um assalto. Acompanhei esse caso de perto e senti que, para aqueles homens, as mulheres eram realmente algo a ser dado de presente, eram objetos, peças utilitárias. Por um momento, toda denúncia dos movimentos sociais feministas de que as mulheres não eram mercadoria fez um sentido real e concreto para mim, e não mais metafórico. Em 25 de setembro de 2014, o chamado mentor do estupro coletivo de Queimadas foi condenado a 107 anos de prisão pelo júri popular ocorrido na cidade de João Pessoa. Houve muita pressão popular pela condenação do acusado.

Entre a constatação das desigualdades de gênero vivenciadas e a observação de tratamento/ abordagem/ construção de personagens femininas / mulheres pelos media e pela publicidade, localiza-se o meu objeto de pesquisa. Isto porque encontrei alguns dados que levaram as minhas preocupações pessoais ao encontro de uma problemática social mais ampla e ainda atual. Um exemplo disso foi o resultado das pesquisas realizadas que mostram indícios da insatisfação das mulheres em relação à veiculação da sua imagem nos media. No livro A imagem da mulher na mídia, Rachel Moreno cita uma pesquisa realizada pela Fundação Perseu Abramo/Sesc, em 2011, na qual se constatou que " $80 \%$ das mulheres consideram que a imagem atual das mulheres na mídia, além de desagradar, contribui para uma desvalorização e subjulgamento geral da figura feminina.".

A sociedade brasileira expressa sua opinião em $b \log s$, rodas de conversas em espaços públicos e movimentos sociais feministas, apresentando denúncias junto ao Conselho Nacional de Autorregulamentação Publicitária - Conar, que elaborou o Código Brasileiro de Autorregulamentação Publicitária e o atualizou em 2008. Em relação às bebidas alcoólicas, o código dispõe no anexo $\mathrm{P}$, artigo $3^{\circ}$, alínea $a$ :

3. Princípio do consumo com responsabilidade social: a publicidade não deverá induzir, de qualquer forma, ao consumo

\footnotetext{
${ }^{1}$ A pesquisa foi realizada em agosto de 2010 e ouviu a opinião de duas mil trezentos e sessenta e cinco mulheres e 1.181 homens, com mais de 15 anos de idade, de 25 unidades da federação, cobrindo as áreas urbanas e rurais de todas as macrorregiões do país. O levantamento envolve a inclusão de 176 municípios na amostra feminina e 104 na masculina. A margem de erro da pesquisa é entre 2 e 4 pontos percentuais para mulheres e entre 3 e 4 pontos para os homens. Em ambos o intervalo de confiança é de $95 \%$.
} 
exagerado ou irresponsável. Assim, diante deste princípio, nos anúncios de bebidas alcoólicas:

a. eventuais apelos à sensualidade não constituirão o principal conteúdo da mensagem; modelos publicitários jamais serão tratados como objeto sexual;(CONAR, 2008).

Também teve importância a ação que o Ministério da Justiça moveu contra a marca de cerveja Devassa, devido a anúncios como o seguinte, veiculados entre 2010 e $2011^{2}$.

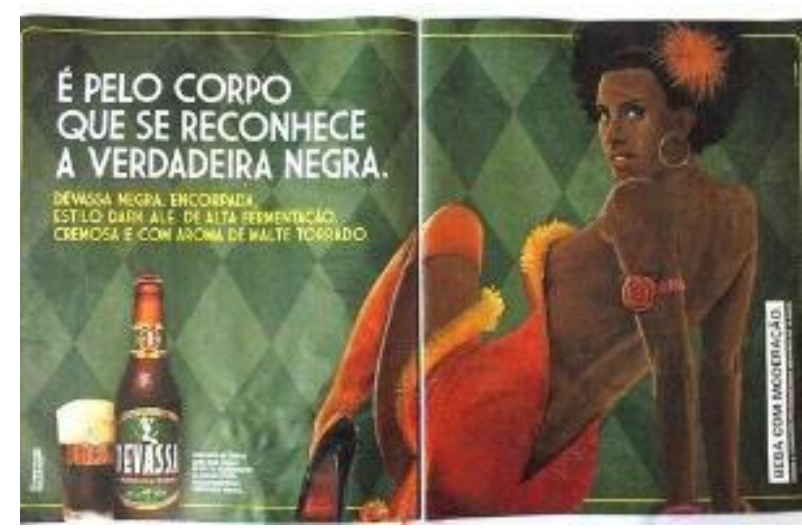

Figura 1 - Anúncio Devassa Negra

Os consumidores entraram com recurso no Conselho Nacional de Autorregulamentação Publicitária (Conar) contra esta peça publicitária em 2010 e o Conar decidiu pela suspensão da publicidade por se tratar de estímulo meramente sensual e desrespeito à pessoa humana, além de incentivar a discriminação. De fato, a peça associa diretamente a personagem negra à bebida, numa relação direta entre produto e personagem. O texto do cartaz diz: "É pelo corpo que se reconhece a verdadeira negra. Devassa negra. Encorpada. Estilo dark ale. De alta fermentação. Cremosa e com aroma de malte torrado".

Além dessas pesquisas e informações citadas, ainda assim nos deparamos com uma realidade brasileira em que as mulheres cada vez mais se inserem no mundo do trabalho como pessoas economicamente ativas, tendo aumentado consideravelmente,

\footnotetext{
2 O Ministério da Justiça (MJ) instaurou processo contra a Devassa a partir de denúncia feita pelo Procon do estado do Espírito Santo que considerou a publicidade abusiva. Entidades de classe e secretarias especializadas foram ouvidas pelo MJ sobre o caso, como a Secretaria de Políticas para as Mulheres, a Secretaria de Políticas de Promoção da Igualdade Racial e o Conselho Federal de Psicologia, que também consideraram a peça publicitária racista apresentando associação direta entre a cerveja e a mulher negra. O processo ainda está em andamento, se condenada, a Devassa terá que pagar multa de 6 milhões.
} 
entre os anos 2000 e 2010, a entrada das mulheres no trabalho formal. No entanto, elas parecem ainda estar longe de serem respeitadas como consumidoras. Em pesquisa realizada pioneiramente pelo Ministério da Saúde, em 2007, com o objetivo de saber qual era o perfil do público consumidor de bebida alcoólica, intitulada I Levantamento Nacional de Padrões de Consumo do Álcool, podemos perceber que as mulheres são responsáveis por cerca de $41 \%$ do consumo de álcool e os homens, por 59\%. A cerveja representa $61 \%$, na média entre as bebidas alcóolicas, da preferência nacional. Nesta pesquisa foram envolvidas duas mil trezentas e quarenta e seis pessoas adultas, com mais de 18 anos, em 143 municípios brasileiros, de todas as classes sociais. Em todas as classes, a cerveja aparece em primeiro lugar. A mesma pesquisa também entrevistou 661 adolescentes entre 14 e 17 anos, faixa etária na qual o consumo de álcool, apesar de proibido, acontece, e não há diferenças significativas no consumo entre meninas e meninos.

Já no II Levantamento Nacional de Álcool e Drogas, realizado pela Universidade Federal de São Paulo (Unifesp) em 2012 , que fez 3.000 entrevistas em todo o território nacional com a população acima de 14 anos, apontou o crescimento do consumo de cerveja entre as mulheres. Nos dados relacionados às pessoas que bebem pelo menos 1 vez por semana, as mulheres passaram de 27\%, em 2006, para 38\%, em 2012. Já no que se relaciona às informações para os não abstinentes que bebem em binge, ou seja, que bebem 5 ou mais de 5 doses pelo menos uma vez ao ano, houve um aumento de $14 \%$ entre as mulheres, passando de 34\%, em 2006, para 48\%, em 2012. Ou seja, esses dados apontam para um crescimento do consumo de bebidas, em sua preferência nacional, de cerveja, pelas mulheres brasileiras.

No entanto, peças publicitárias de cerveja ainda trazem uma alta dose de sensualidade relacionada às mulheres. Neste sentido, a sociedade poderia cumprir um papel essencial nas denúncias e no controle sobre os excessos, mas essa capacidade crítica não é suficiente para regular a publicidade brasileira.

Cabe considerar a diferença entre regulação e regulamentação publicitárias: "A regulação seria um processo maior de gestão do interesse público, a partir da oferta de produtos, serviços de um dado setor, implicando em regulações do consumo, econômicas, de saúde pública e da comunicação deste setor." (TRINDADE, 2012, p. 220). Ou seja, um setor específico de atuação empresarial seria regulado por agências que instituiriam todas as regras de atuação desse setor, sejam econômicas, de consumo, 
de saúde ou em relação à publicização de seus produtos e transparência das informações sobre seus efeitos. Já a regulamentação diz respeito, especificamente, a lei, normatização, elaboração de normas e códigos que visam atender os interesses sociais acima dos da empresa.

No mesmo artigo em que apresenta esta distinção entre regulamentação e regulação, Trindade (2012) critica a atuação do Conar, apontando-a como frágil, já que realiza a autorregulamentação do setor de publicidade e o fato de se autorregulamentar, por si só, já é uma questão problemática. Ele cita um exemplo dessa fragilidade:

Essa atuação frágil do CONAR fica demonstrada em estudo desenvolvido por VENDRAME, PISNKY, SILVA e BABOR (2007/2008), que perceberam entre cinco propagandas de cerveja, indicadas como mais atraentes por adolescentes de 15 a 17 anos investigados que, das 16 normas do CONAR, 11 haviam sido violadas nas cinco mensagens. E nenhuma delas sofreu qualquer tipo de denúncia ou processo pelo referido órgão. (TRINDADE, 2012, p. 220).

Recentemente, a regulamentação da publicidade de bebidas tem passado por debates na Justiça, já que a Lei Seca usa a graduação do teor alcóolico baseada na Política Nacional sobre Álcool, decreto 6.111/2007, que restringe bebidas com teor igual ou acima de $0,5^{\circ}$ Gay Lussac (GL) e por isso requer que a veiculação de publicidade de bebidas com teor igual ou acima de 0,5 , no caso de vinhos e cerveja, passe a ser feita a partir das $21 \mathrm{~h}$.

Assim como no artigo de Trindade (2012), que tem como objetivo analisar o estímulo ao consumo de cerveja por menores de 18 anos, também é nossa intenção, refletir como a ausência de regulação e regulamentação deste setor provoca práticas de consumo aliadas a práticas sociais seja refletindo- as ou reforçando- as.

Inicialmente, de forma superficial, ainda no processo de feitura do projeto de pesquisa para participar da seleção de mestrado e, mais detalhadamente, durante o processo de pesquisa do mestrado, havíamos observado algumas peças publicitárias de cerveja da última década e percebemos que a maioria das campanhas que tinham mulheres como personagens apresentam-nas em condições de objetificação ou assumindo papéis erotizados. Por outro lado, identificamos que o masculino construído nestas peças também remetia a possibilidades marcadamente construídas para uma masculinidade hegemônica (CONNEL, 1995) e heterossexual. Em seguida, partimos 
para o desenvolvimento desta pesquisa, de um lado, diante da ânsia de entender as causas da continuidade do uso estereotipado de mulheres e homens na publicidade, já que houve mudanças sociais nos papéis desempenhados por ambos os gêneros, e, de outro, da necessidade de compreender essas significações para o receptor da mensagem e as mudanças e continuidades presentes na publicidade de cerveja no que se refere à criação publicitária.

Para isso, escolhemos estudar a marca de cerveja Skol, pois esta tem se posicionado como uma marca que sempre se renova e inova. No entanto, a abordagem das relações de gênero em suas peças publicitárias acompanha as inovações da marca? A Skol foi criada em 1967 e, segundo pesquisa Interbrand ${ }^{3}$ realizada em 2014, ocupa a $1^{\mathrm{a}}$ posição entre as marcas brasileiras mais valiosas de 2014 , valendo mais de 7 bilhões de dólares. Hoje é fabricada pela AmBev e comercializada nos tipos Pilsen, beats, chope claro e escuro. Lançou a primeira cerveja em lata do Brasil (1971) e também foi pioneira nos formatos lata de alumínio (1989), long neck com tampa de rosca (1993), latão (1993), Skol litrão (2008).

A estratégia da Skol esteve focada na inovação dos produtos e no aprimoramento do design das embalagens, uma forma de se diferenciar das demais marcas de cerveja e associar o visual do produto à singularidade de quem escolhe Skol, por isso elegemos a mesma como a marca de cerveja a ser analisada nesta pesquisa. Além disso, de acordo com pesquisa realizada pela BrandAnalytics/Millward Brown, a Skol foi a marca brasileira mais valiosa em 2013 e em 2014.

A nossa inquietação nasce dessa tensão entre novas estratégias publicitárias utilizadas atualmente e a abordagem das relações de gênero nas peças publicitárias. Desse modo, nosso problema de pesquisa pode ser resumido na seguinte pergunta: Em que medida a criação publicitária inova na abordagem das relações de gênero? Com base nesta indagação, propomos investigar a construção da personagem feminina e masculina pela marca de cerveja Skol, nos últimos 17 anos, observando a construção das relações de gênero no conteúdo dos vídeos publicitários veiculados na televisão aberta brasileira, desta marca, em relação à construção das relações de gênero. Com isso queremos analisar a construção de imagem, som,

\footnotetext{
${ }^{3}$ Pesquisa Interbrand $\quad$ Marcas Brasileiras Mais Valiosas 2014, disponível em http://www.meioemensagem.com.br/home/marketing/noticias/2014/04/25/Skol-e-bicampea-como-marca-mais-valiosa.html. Acesso em 01/11/2014.
} 
discurso e imaginário no que se refere às relações de gênero na publicidade.

\section{Os estudos sobre Publicidade e Mulheres}

A relação entre a publicidade e as formas de representação das mulheres tem levado muitos a se debruçarem sobre esta temática. (ROCHA, 2006; CARVALHO, 2002; MORIN, 1969; PIRES, 2007; RAMOS, 2006; LARA, 2007; SILVEIRA, 2013; ZAMBONI, 2013; CAMPOS, 2010; BRISOLLA, 2006; DIAS, 2011, SHAW, 2003). A representação de um mundo imagético, envolvendo personagens e estímulos visuais capazes de influenciar emoções e desejos, ao integrarem narrativas publicitárias, é um campo fértil para refletir as trocas culturais e simbólicas da nossa sociedade, que Baudrillard (2008) define como sociedade de consumo e que tem a felicidade como referência. Também é associada ao prazer e tem como herdeira o mito da igualdade, da Revolução Industrial Francesa. (BAUDRILLARD, 2008).

Featherstone (1995) dialoga com Baudrillard ao caracterizar a cultura do consumo também por diferenciação, desejos e especialização. No entanto, ele acrescenta uma categoria ao consumo, estilos de vida. Para Featherstone (1995), a cultura do consumo tanto tem a ver com a produção de mercadorias e, portanto, depende da lógica imposta pelo mercado, quanto com o fato de construir relações sociais, na medida em que o consumo de um produto específico pode dissolver diferenças sociais ou gerar barreiras. Nesta perspectiva, os produtos têm dimensões simbólicas distintas. Por exemplo, para um grupo, um vinho é apenas uma bebida, mas para outro grupo, pode ser de uma safra rara e possuir outro valor de consumo que o distingue dos demais. Para Featherstone (1995), o consumo é um meio de realização de desejos e sonhos pessoais e por isso não pode ser visto, exclusivamente, como uma produção do mercado ou do capital, pois organiza princípios integrativos mais profundos: estilos de vida que demarcam relações sociais. A partir dos modos de consumo, as pessoas são classificadas e interpretadas pelos estilos adotados.

Usar a expressão "cultura de consumo" significa enfatizar que o mundo das mercadorias e seus princípios de estruturação são centrais para a compreensão da sociedade contemporânea. Isso envolve um foco duplo: em primeiro lugar, na dimensão cultural da economia, a simbolização e o uso de bens materiais como "comunicadores", não apenas como utilidades; em segundo lugar, na economia dos bens culturais, os princípios de mercado (...) que operam dentro da esfera dos estilos de vida, bens culturais e mercadorias. (FEATHERSTONE, 1995, p. 101).

Já Edgar Morin (1969) relaciona publicidade e cultura de massa. Ele reflete 
sobre a cultura de massa e seu caráter estético e transcendental, que ocupa uma espécie de Mitologia Moderna, ou seja, ao mesmo tempo em que projeta uma vida desejável e um bem-estar com os produtos de consumo, representa as aspirações privadas: o afeto, o amor e o sucesso.

A cultura de massa [...] desenvolve no imaginário e na informação romanceada os temas da felicidade pessoal, do amor e da sedução. Essa complementaridade concerne ao mesmo tecido humano que á a vida privada. Daí a estreita ligação entre publicidade e cultura de massa. A publicidade apadrinha tão bem a cultura de massa (programas de rádio e televisão, competições esportivas) quanto é apadrinhada por ela. [...] A cultura de massa, em certo sentido, é um aspecto publicitário do desenvolvimento do consumidor do mundo ocidental. Num outro sentido, a publicidade é um aspecto da cultura de massa, um de seus prolongamentos práticos. (MORIN, 1969, p. 104)

Portanto, a publicidade possui laços fundamentais com a cultura de massa, tanto porque impulsiona esta cultura, quanto porque é impulsionada por ela. Disso decorre a importância de estudar esta relação entre cultura e consumo, que no caso da cultura de massa, são processos misturados e dependentes. Já em relação aos estudos de gênero, observados a partir do fenômeno da cultura de massa com o surgimento dos meios de comunicação em grande escala, a preocupação foi entender a ligação entre mulheres e consumo e entre mulheres e cultura. Nos 17 últimos anos, pesquisas têm sido realizadas com abordagens diferentes relacionadas à imagem da mulher nos meios de comunicação. Numa breve consulta aos repositórios institucionais de algumas universidades, encontramos o seguinte resultado relacionado à utilização das mulheres na publicidade brasileira:

\begin{tabular}{|c|c|c|c|c|}
\hline & Título & Objetivo & Metodologia & $\begin{array}{l}\text { Resultados } \\
\text { Alcançados }\end{array}$ \\
\hline 1. & $\begin{array}{l}\text { Mulheres em } \\
\text { Profusão: imagens } \\
\text { das mulheres na } \\
\text { propaganda } \\
\text { impressa brasileira } \\
\text { (1957 a 1997). } \\
\text { Autora: Monique } \\
\text { Vidal Pires. } \\
\text { Ano: } 2007 \\
\text { (dissertação História }\end{array}$ & $\begin{array}{l}\text { "O trabalho pretende } \\
\text { analisar as imagens de } \\
\text { mulheres que foram } \\
\text { veiculadas nas } \\
\text { propagandas impressas } \\
\text { brasileiras, em revistas } \\
\text { dirigidas ao público em } \\
\text { geral - O cruzeiro, } \\
\text { Manchete e Veja- } \\
\text { entre } 1957 \text { e } 1997 " .\end{array}$ & $\begin{array}{l}\text { Analisa as imagens } \\
\text { publicitárias observando } \\
\text { as representações sociais } \\
\text { das mulheres e o } \\
\text { imaginário circulante no } \\
\text { período em que foram } \\
\text { produzidas, para, assim, } \\
\text { identificar a existência de } \\
\text { matrizes de sentido que } \\
\text { operam inserindo ou }\end{array}$ & $\begin{array}{l}\text { A publicidade se } \\
\text { manteve alheia as } \\
\text { mudanças nos } \\
\text { empreendida pelas } \\
\text { mulheres no } \\
\text { período de } 1957 \text { a } \\
\text { 1997, frisando os } \\
\text { papéis tradicionais } \\
\text { e "mantendo as } \\
\text { representações }\end{array}$ \\
\hline
\end{tabular}




\begin{tabular}{|c|c|c|c|c|}
\hline & UnB) & & $\begin{array}{l}\text { excluindo valores, } \\
\text { ressignificando conceitos } \\
\text { e preconceitos, a partir } \\
\text { da perspectiva da escola } \\
\text { francesa da análise de } \\
\text { discurso. }\end{array}$ & $\begin{array}{l}\text { sociais } \\
\text { tradicionais, } \\
\text { reiterando o status- } \\
\text { quo e até mesmo } \\
\text { reforçando } \\
\text { estereótipos } \\
\text { negativos, como } \\
\text { "bundalização", } \\
\text { tão evidentes hoje } \\
\text { na mídia Dessa } \\
\text { forma, vemos } \\
\text { como a propaganda } \\
\text { possui uma } \\
\text { identidade dupla - } \\
\text { de produtora e } \\
\text { produto do } \\
\text { imaginário e das } \\
\text { condições de } \\
\text { produção das } \\
\text { épocas em que } \\
\text { foram criadas. }\end{array}$ \\
\hline 2. & $\begin{array}{l}\text { E a mídia criou a } \\
\text { mulher: como a tv e } \\
\text { o cinema constroem } \\
\text { o sistema } \\
\text { sexo/gênero. } \\
\text { Autora: Liliane } \\
\text { Maria Macedo } \\
\text { Machado. } \\
\text { Ano: } 2006 . \text { (Tese } \\
\text { História UnB) }\end{array}$ & $\begin{array}{l}\text { "A pesquisa tem por } \\
\text { objetivo empreender a } \\
\text { análise das matrizes } \\
\text { discursivas referente às } \\
\text { mulheres, presentes } \\
\text { nos filmes de animação } \\
\text { A Bela e A fera, A } \\
\text { Bela e A Fera: O natal } \\
\text { encantado, Mulan } \\
\text { Mulan: a saga } \\
\text { continua, Shrek e } \\
\text { Shrek } 2 \text { bem como nos } \\
\text { desenhos animados } \\
\text { Meninas } \\
\text { Superpoderosas e Três } \\
\text { Espiãs Demais." }\end{array}$ & $\begin{array}{l}\text { Observa o interdiscurso } \\
\text { entre as fontes } \\
\text { escolhidas, analisando as } \\
\text { condições de } \\
\text { possibilidade que } \\
\text { originam as } \\
\text { representações acerca das } \\
\text { mulheres e como estão } \\
\text { construídas as cenas } \\
\text { enunciativas dos filmes e } \\
\text { desenhos. }\end{array}$ & $\begin{array}{l}\text { "Os estudos } \\
\text { feministas e de } \\
\text { gênero } \\
\text { permitiram-me } \\
\text { perceber que as } \\
\text { matrizes } \\
\text { promovem o } \\
\text { binarismo } \\
\text { contribuindo para } \\
\text { a sustentação do } \\
\text { sistema de sexo- } \\
\text { gênero atual, o } \\
\text { qual designa } \\
\text { lugares } \\
\text { diferenciados para } \\
\text { homens e } \\
\text { mulheres." }\end{array}$ \\
\hline 3. & $\begin{array}{l}\text { Sedução e desejo - } \\
\text { representações da } \\
\text { mulher nos anúncios } \\
\text { de perfumes } \\
\text { femininos. } \\
\text { Autora: Krishna } \\
\text { Figueiredo de } \\
\text { Almeida Ramos. } \\
\text { Ano 2006. } \\
\text { (Dissertação } \\
\text { Comunicação UnB) }\end{array}$ & $\begin{array}{l}\text { "Para analisar como as } \\
\text { mulheres são } \\
\text { mostradas nos } \\
\text { anúncios, ou seja, que } \\
\text { tipo de mulheres são } \\
\text { reconhecidos na } \\
\text { publicidade, e porque } \\
\text { certos comportamentos } \\
\text { sociais femininos são } \\
\text { valorizados por meio } \\
\text { da ubiquidade das } \\
\text { imagens é que } \\
\text { apresento este } \\
\text { trabalho". }\end{array}$ & $\begin{array}{l}\text { Analisa as revistas Nova } \\
\text { /Cosmopolitan, Elle } \\
\text { Brasil, Marie Claire e } \\
\text { Estilo de Vida } \\
\text { observando aspectos } \\
\text { como cores, posições da } \\
\text { modelo, direção dos } \\
\text { olhares, com o intuito de } \\
\text { perceber significados } \\
\text { neste tipo de publicidade. } \\
\text { Os estudos culturais } \\
\text { foram utilizados como } \\
\text { referencial teórico. }\end{array}$ & $\begin{array}{l}\text { "[...] a brasileira } \\
\text { consome, sim } \\
\text { representações de } \\
\text { mulheres } \\
\text { estrangeiras, o } \\
\text { que nada mais é } \\
\text { do que uma traço } \\
\text { da hegemonia } \\
\text { econômica dos } \\
\text { países produtores } \\
\text { de perfumes, } \\
\text { cosméticos em } \\
\text { geral e qualquer } \\
\text { outro produto que } \\
\text { precise de grandes } \\
\text { mercados } \\
\text { consumidores. Se } \\
\text { as representações } \\
\text { trazem em si o } \\
\text { imaginário e os }\end{array}$ \\
\hline
\end{tabular}




\begin{tabular}{|c|c|c|c|c|}
\hline & & & & $\begin{array}{l}\text { valores, o que } \\
\text { será que a } \\
\text { brasileira que } \\
\text { raramente se vê } \\
\text { identificada pode } \\
\text { pensar de sua } \\
\text { aparência, de sua } \\
\text { etnia, de seus } \\
\text { traços diferentes } \\
\text { dos de um } \\
\text { europeia, por } \\
\text { exemplo? As } \\
\text { consequências } \\
\text { podem partir } \\
\text { desde um âmbito } \\
\text { mais íntimo, em } \\
\text { que ela não se } \\
\text { reconhece como } \\
\text { válida para } \\
\text { participar } \\
\text { ativamente da } \\
\text { sociedade e, } \\
\text { assim, passa a } \\
\text { desgostar de suas } \\
\text { origens”. }\end{array}$ \\
\hline 4. & $\begin{array}{l}\text { Representação de } \\
\text { mulher nos } \\
\text { comerciais de } \\
\text { automóveis: garota é } \\
\text { apenas equipamento } \\
\text { opcional } \\
\text { Autora: Andréa de } \\
\text { Almeida Lara } \\
\text { Ano: } 2007 \\
\text { (Dissertação } \\
\text { Comunicação UnB) }\end{array}$ & $\begin{array}{l}\text { "esta dissertação } \\
\text { identifica as } \\
\text { representações sociais } \\
\text { femininas presentes em } \\
\text { comerciais de carros } \\
\text { das décadas de } 1950 \text { a } \\
1990 \text { no Brasil". }\end{array}$ & $\begin{array}{l}\text { Utiliza a abordagem dos } \\
\text { Estudos Culturais na } \\
\text { análise dos produtos } \\
\text { midiáticos e a Teoria das } \\
\text { Representações Sociais, a } \\
\text { Análise de Conteúdo e a } \\
\text { Análise do Discurso } \\
\text { Publicitário. }\end{array}$ & $\begin{array}{l}\text { "Os resultados } \\
\text { indicaram, } \\
\text { principalmente, } \\
\text { que as mulheres } \\
\text { foram retratadas } \\
\text { nesses comerciais } \\
\text { a partir de três } \\
\text { representações: } \\
\text { mulher dona-de- } \\
\text { casa, mulher } \\
\text { objeto e mulher- } \\
\text { cenário. Essas } \\
\text { representações } \\
\text { foram definidas } \\
\text { considerando-se } \\
\text { características } \\
\text { recorrentes como } \\
\text { roupas e } \\
\text { acessórios } \\
\text { utilizados pelas } \\
\text { mulheres, tipos de } \\
\text { carro em que } \\
\text { aparecem e } \\
\text { características da } \\
\text { produção desses } \\
\text { comerciais, além } \\
\text { dos discursos } \\
\text { publicitários dos } \\
\text { comerciais. } \\
\text { Depreende-se que } \\
\text { tais construções } \\
\text { se articulam com } \\
\text { a forma como as }\end{array}$ \\
\hline
\end{tabular}




\begin{tabular}{|c|c|c|c|c|}
\hline & & & & $\begin{array}{l}\text { mulheres são } \\
\text { vistas nesse } \\
\text { âmbito social } \\
\text { brasileiro, uma } \\
\text { vez que os meios } \\
\text { de comunicação } \\
\text { colaboram para a } \\
\text { construção sócio- } \\
\text { histórica de nossa } \\
\text { sociedade." }\end{array}$ \\
\hline 5. & $\begin{array}{l}\text { O consumo da } \\
\text { magreza: A } \\
\text { publicidade como } \\
\text { ideal da felicidade. } \\
\text { Autora: Beatriz } \\
\text { Oliveira Silveira, } \\
\text { Ano: } 2013 \\
\text { (Dissertação } \\
\text { Comunicação UnB) }\end{array}$ & $\begin{array}{l}\text { "O objetivo é entender } \\
\text { quais elementos uma } \\
\text { peça publicitária } \\
\text { apresenta como } \\
\text { incentivo à adesão ao } \\
\text { projeto de felicidade } \\
\text { baseado na conquista } \\
\text { de um corpo esbelto." }\end{array}$ & $\begin{array}{l}\text { Através da análise de } \\
\text { conteúdo de uma } \\
\text { campanha de lingerie } \\
\text { lançada pelas Lojas } \\
\text { Renner em } 2011 \text { realiza } \\
\text { um levantamento das } \\
\text { categorias que ilustram a } \\
\text { problemática. }\end{array}$ & $\begin{array}{l}\text { "É possível } \\
\text { observar que o } \\
\text { comportamento } \\
\text { das protagonistas, } \\
\text { as cores das } \\
\text { lingeries que } \\
\text { trajam, a música } \\
\text { que embala toda a } \\
\text { movimentação no } \\
\text { decorrer da peça e } \\
\text { a narrativa nela } \\
\text { contida, bem } \\
\text { como a assinatura } \\
\text { das Lojas Renner, } \\
\text { auxiliam na } \\
\text { disseminação da } \\
\text { magreza. Apesar } \\
\text { de a campanha } \\
\text { conter duas } \\
\text { modelos plus size, } \\
\text { o uso excessivo } \\
\text { de atrizes magras } \\
\text { em conjunto com } \\
\text { os demais } \\
\text { elementos que } \\
\text { favorecem a } \\
\text { construção de } \\
\text { uma sensualidade } \\
\text { pautada na } \\
\text { magreza, } \\
\text { funcionam como } \\
\text { incentivadores da } \\
\text { busca por esse } \\
\text { padrão corporal. }\end{array}$ \\
\hline 6. & $\begin{array}{l}\text { Para que serve a } \\
\text { mulher do anúncio? } \\
\text { Um estudo sobre } \\
\text { representações de } \\
\text { gênero nas imagens } \\
\text { publicitárias. } \\
\text { Autora: Júlia Simões } \\
\text { Zamboni. } \\
\text { Ano: 2013. } \\
\text { (Dissertação } \\
\text { Comunicação UnB) }\end{array}$ & $\begin{array}{l}\text { "O Objetivo é entender } \\
\text { as representações de } \\
\text { gênero construídas pelo } \\
\text { discurso publicitário a } \\
\text { partir da ótica do } \\
\text { construtivismo de } \\
\text { gênero." }\end{array}$ & $\begin{array}{l}\text { Analisa as peças } \\
\text { publicitárias com o } \\
\text { suporte das teorias de } \\
\text { análise da imagem, } \\
\text { tendo como base } \\
\text { metodológica a análise } \\
\text { dos componentes da } \\
\text { imagem e seu significado } \\
\text { na nossa cultura } \\
\text { ocidental. }\end{array}$ & $\begin{array}{l}\text { "Mesmo com as } \\
\text { mudanças atuais } \\
\text { na forma de } \\
\text { representação da } \\
\text { mulher, podemos } \\
\text { dizer que a } \\
\text { publicidade ainda } \\
\text { reproduz valores } \\
\text { arcaicos, } \\
\text { mantendo a } \\
\text { publicidade no } \\
\text { mesmo } \\
\text { enquadramento } \\
\text { vigente no início }\end{array}$ \\
\hline
\end{tabular}




\begin{tabular}{|c|c|c|c|c|}
\hline & & & & $\begin{array}{l}\text { do século XX. A } \\
\text { mulher como } \\
\text { enfeite, como } \\
\text { acessório de luxo, } \\
\text { a mulher-objeto, a } \\
\text { mulher-corpo que } \\
\text { agrega valor ao } \\
\text { produto, a } \\
\text { sensualidade da } \\
\text { mulher associada } \\
\text { fortemente ao } \\
\text { produto de modo } \\
\text { a fixar no } \\
\text { imaginário } \\
\text { masculino o } \\
\text { slogan "compre o } \\
\text { produto e leve a } \\
\text { mulher de } \\
\text { brinde". Todas } \\
\text { essas concepções } \\
\text { estão mantidas e } \\
\text { reproduzidas } \\
\text { atualmente, } \\
\text { principalmente } \\
\text { nas publicidades } \\
\text { de cerveja." }\end{array}$ \\
\hline 7. & $\begin{array}{l}\text { A figura da mulher } \\
\text { na linguagem da } \\
\text { propaganda - } \\
\text { implicações sociais. } \\
\text { Autora: Débora } \\
\text { Mendes Campos. } \\
\text { Ano: } 2010 . \\
\text { (Dissertação } \\
\text { Sociologia UFSCar) }\end{array}$ & $\begin{array}{l}\text { Este trabalho trata da } \\
\text { utilização da imagem } \\
\text { de corpos femininos na } \\
\text { publicidade, com base } \\
\text { na análise de um } \\
\text { conjunto representativo } \\
\text { de peças publicitárias } \\
\text { transmitidas pela } \\
\text { televisão aberta } \\
\text { brasileira. }\end{array}$ & $\begin{array}{l}\text { Utiliza uma perspectiva } \\
\text { macro-sociológica } \\
\text { baseada na teoria crítica } \\
\text { de Adorno e Horkheimer } \\
\text { (1985), além de outros } \\
\text { autores que com eles } \\
\text { dialogam, para } \\
\text { compreender os } \\
\text { pressupostos estruturais } \\
\text { subjacentes às } \\
\text { mensagens publicitárias. }\end{array}$ & $\begin{array}{l}\text { "Identificou-se } \\
\text { que a ordem } \\
\text { social } \\
\text { androcêntrica } \\
\text { nelas predomina, } \\
\text { sobretudo calcada } \\
\text { em imagens } \\
\text { ligadas ao } \\
\text { erotismo, usado } \\
\text { como veículo das } \\
\text { organizações } \\
\text { contemporâneas } \\
\text { ligadas à } \\
\text { produção, } \\
\text { veiculação e } \\
\text { recepção da } \\
\text { cultura, de que a } \\
\text { propaganda é a } \\
\text { linguagem por } \\
\text { excelência. } \\
\text { Nesses moldes, ao } \\
\text { veicular } \\
\text { estereótipos } \\
\text { femininos e } \\
\text { masculinos, a } \\
\text { publicidade cria } \\
\text { modelos de } \\
\text { projeção e } \\
\text { identificação, ou } \\
\text { seja, padrões de } \\
\text { comportamentos a } \\
\text { serem }\end{array}$ \\
\hline
\end{tabular}




\begin{tabular}{|c|c|c|c|c|}
\hline & & & & $\begin{array}{l}\text { internalizados, } \\
\text { tornando-se um } \\
\text { veículo } \\
\text { privilegiado da } \\
\text { ideologia de } \\
\text { gênero." }\end{array}$ \\
\hline 8. & $\begin{array}{l}\text { Representação da } \\
\text { mulher na campanha } \\
\text { pela real beleza } \\
\text { Dove: um estudo dos } \\
\text { processos de } \\
\text { significação em } \\
\text { imagens } \\
\text { publicitárias. } \\
\text { Autora: Marcia } \\
\text { Regina Santos } \\
\text { Brisolla. } \\
\text { Ano: 2006 } \\
\text { (Dissertação Artes } \\
\text { Visuais UFG) }\end{array}$ & $\begin{array}{l}\text { "O presente trabalho } \\
\text { tem como objetivo } \\
\text { analisar a representação } \\
\text { da } \\
\text { mulher nos anúncios } \\
\text { impressos da campanha } \\
\text { pela real beleza Dove, } \\
\text { veiculados no Brasil, } \\
\text { no período de } 2004 \text { a } \\
\text { 2005." }\end{array}$ & $\begin{array}{l}\text { Utiliza o referencial } \\
\text { teórico dos estudos } \\
\text { culturais e de gênero para } \\
\text { identificar a forma que a } \\
\text { mulher está sendo } \\
\text { representada na ediçãō } \\
\text { brasileira da campanha } \\
\text { pela real beleza Dove. }\end{array}$ & $\begin{array}{l}\text { “[...]a análise } \\
\text { revelou que os } \\
\text { anúncios } \\
\text { publicitários } \\
\text { reforçam o status } \\
\text { quo por meio da } \\
\text { prática repetitiva } \\
\text { das normas sócio- } \\
\text { culturais que } \\
\text { mantém como } \\
\text { padrão de } \\
\text { referência a } \\
\text { mulher como } \\
\text { sendo branca, } \\
\text { cabelos lisos, } \\
\text { classe média, } \\
\text { corpo } \\
\text { visivelmente bem } \\
\text { cuidado mesmo } \\
\text { com alguns quilos } \\
\text { a mais, enquanto } \\
\text { excluem aquelas } \\
\text { que não se } \\
\text { adaptam a essas } \\
\text { normas.[...] } \\
\text { reforçam a } \\
\text { exposição do } \\
\text { corpo da mulher } \\
\text { submetido a } \\
\text { projeções sociais } \\
\text { para } \\
\text { contemplação e } \\
\text { consumo.” }\end{array}$ \\
\hline 9. & $\begin{array}{l}\text { Loira gelada, loira } \\
\text { gostosa: um estudo } \\
\text { de representações } \\
\text { imagéticas femininas } \\
\text { em peças } \\
\text { publicitárias de } \\
\text { cerveja. } \\
\text { Autor: Fábio } \\
\text { Barbosa Dias. } \\
\text { Ano: 2011 } \\
\text { (Dissertação } \\
\text { Comunicação Uel) }\end{array}$ & $\begin{array}{l}\text { Este trabalho estuda as } \\
\text { representações } \\
\text { femininas nas } \\
\text { propagandas de cerveja } \\
\text { para a mídia impressa } \\
\text { utilizando, entre outras } \\
\text { ferramentas, os três } \\
\text { eixos de produção de } \\
\text { sentidos colocados por } \\
\text { Harry Pross, buscando } \\
\text { perceber seu poder } \\
\text { discursivo. }\end{array}$ & $\begin{array}{l}\text { Analisa a partir de Pross, } \\
\text { Luciano Guimarães e } \\
\text { Norval Baitello Júnior } \\
\text { para identificar os eixos } \\
\text { de produção de sentido } \\
\text { utilizados nas campanhas } \\
\text { publicitárias de diversas } \\
\text { marcas de cerveja } \\
\text { veiculadas na primeira } \\
\text { década dos anos } 2000 .\end{array}$ & $\begin{array}{l}\text { “[...] constatou-se } \\
\text { que na maioria } \\
\text { das vezes a } \\
\text { associação entre a } \\
\text { imagem feminina } \\
\text { e a cerveja se dá a } \\
\text { partir de relações } \\
\text { estabelecidas com } \\
\text { a aparência } \\
\text { "gostosa” da } \\
\text { modelo e o sabor } \\
\text { da bebida, a } \\
\text { sensação de } \\
\text { êxtase que as } \\
\text { expressões físicas } \\
\text { da modelo } \\
\text { suscitam e o } \\
\text { prazer que o } \\
\text { consumo da }\end{array}$ \\
\hline
\end{tabular}




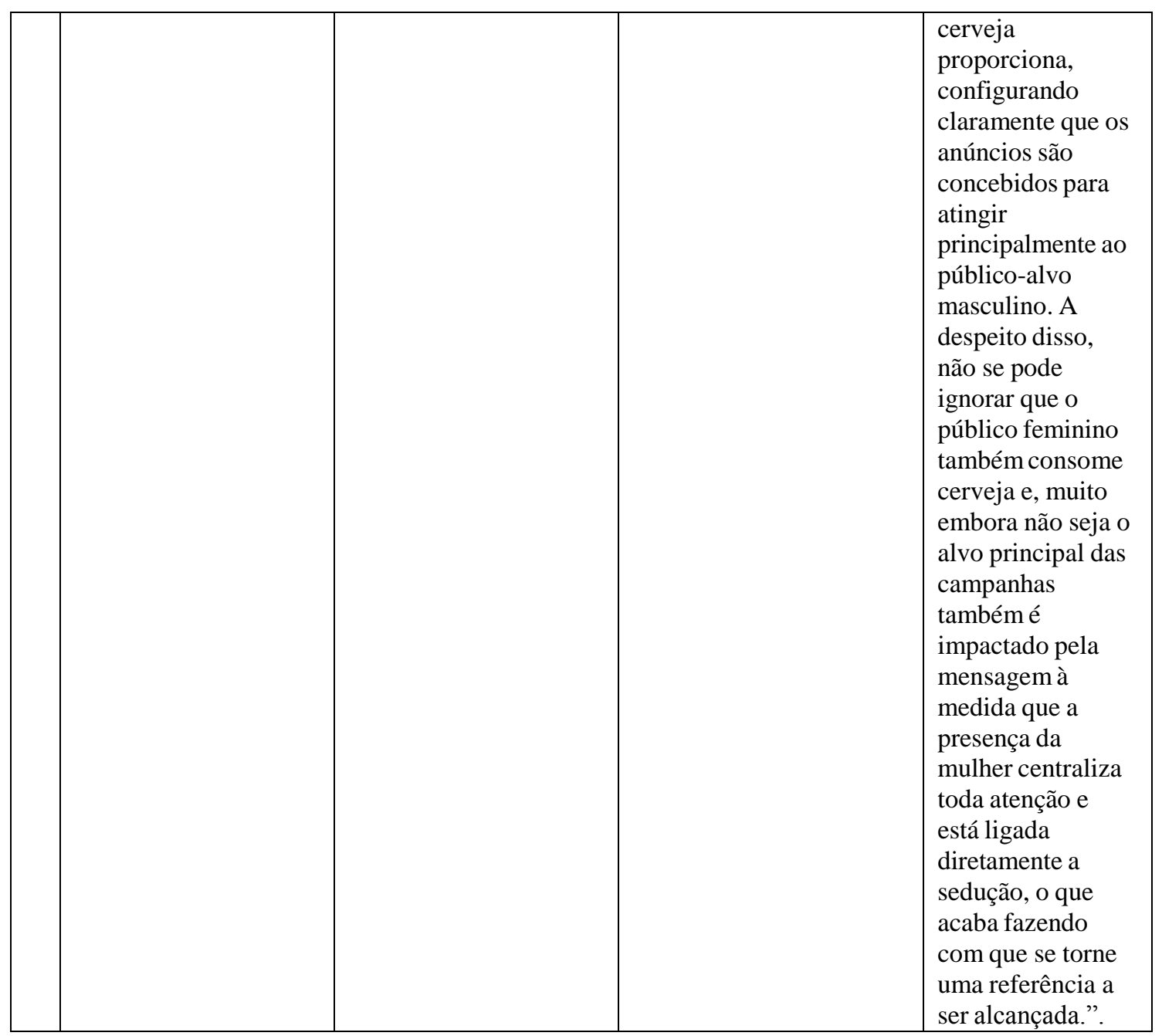

Tabela 1 - Revisão de Literatura

As pesquisas sobre este tema se diferenciam. Uns observam o tratamento dado à mulher nas peças publicitárias. Outros, o discurso publicitário e sua relação com o erótico, a utilização do corpo feminino como objeto, a coisificação das mulheres, a violência simbólica. Há também abordagens que discutem a falta de leis que regulem a exposição e o tratamento dado às mulheres na publicidade e nos media, de forma geral, como o livro A imagem da mulher na mídia, de Rachel Moreno (2011). Os estudos intitulados feministas também discutem o uso das mulheres na publicidade, sob a ótica de tecnologia de gênero, como na tese $E$ a mídia criou a mulher, de Liliane Maria Machado, (2006), e Para que serve a mulher do anúncio?, de Júlia Zamboni (2013).

Esta temática tem instigado muitos estudos e levado vários pesquisadores (as) à inquietação ou ao incômodo com a construção das personagens femininas na publicidade, o que ao nosso ver, é justificado por Nelly de Carvalho (2002) ao 
afirmar que:

A publicidade induz a uma visão dinâmica do social, privilegiando implicitamente as ideias mais atuais, os fatos em emergência, as inovações tecnológicas, as correntes de última hora. O texto publicitário, qualquer que seja a mensagem implícita, é o testemunho de uma sociedade de consumo e conduz a uma representação da cultura a que pertence, permitindo estabelecer uma relação pessoal com a realidade particular. Sua mensagem primeira e explícita é o estímulo ao consumo de um produto, mas ele põe em destaque determinado aspecto de uma cultura, como um projetor poderoso, sem deixar de criar em torno de si algumas zonas de sombra. (CARVALHO, 2002, p. 106).

Portanto, o estudo das relações de gênero na publicidade pode apresentar indícios da sociedade de consumo na atualidade e evidenciar as representações de gênero na nossa cultura, o que fundamenta a importância da nossa pesquisa.

Também se torna importante para nós observar as continuidades e rupturas na construção das relações de gênero pela publicidade de cerveja. Para isto, os estudos sobre criatividade também serão utilizados como formas de analisar as possíveis inovações apresentadas pela criação publicitária. Ou seja, se a publicidade é uma atividade fortemente baseada no emprego da criatividade para criar enredos novos e assim promover a comunicação dos produtos entre o público a que se dirige, então os estudos de criatividade podem constituir um importante embasamento para a reflexão sobre o processo de criação das peças, sobre a forma e também sobre a recepção das mesmas. 


\section{REFERENCIAIS TEÓRICOS}

Para compreendermos nosso tema e objeto de estudo vamos utilizar os referenciais teóricos dos estudos culturais, de gênero, da publicidade e da criatividade.

\section{Estudos Culturais}

A corrente teórica dos Estudos Culturais foi demasiadamente importante para estabelecer, no campo da Comunicação, a preocupação com esta temática. Os estudos feministas dos anos 1970, de acordo com Escosteguy (2008), renderam espaço às mulheres, na perspectiva da abordagem culturalista, para discutirem suas problemáticas. Se o que se estava discutindo era a capacidade de resistência da cultura popular e questionava-se o poder, que era o cerne da abordagem culturalista, o machismo então entrava em pauta, já que as mulheres também queriam questionar o poder dos homens sobre elas. De certa maneira, os Estudos Culturais remetem ao surgimento de uma tendência do período pós-moderno em lançar mão sobre a esquecida e secundarizada cultura e trazê-la para o centro das discussões acadêmicas (FEATHERSTONE, 1995).

A tradição dos Estudos Culturais de Birminghan, primeiramente, ocupou-se em entender as relações entre cultura popular e meios de comunicação de massa. O primeiro momento desses estudos, no início dos anos 1960, foi marcado por reflexões sobre a resistência da cultura popular às mensagens midiáticas, ou seja, mesmo diante do poder dos meios, as culturas populares não desapareciam. Diferentemente do que dizia, em princípio, a Escola de Frankfurt, que acreditava na homogeneização da cultura, na padronização, o que se descobre é a diversidade e pluralidade da cultura, mesmo diante dos meios de comunicação de massa. No entanto, a segunda fase, da década de 1970, é marcada pela ascensão dos meios de comunicação que passam a ser vistos não somente como entretenimento, mas como "Aparelhos Ideológicos de Estado", conceito utilizado por Althusser (1973, p. 42- 43) para definir uma série de instituições que funcionavam como parte destes Aparelhos, como:

O AIE religioso (o sistema das diferentes Igrejas), o AIE escolar (o sistema das diferentes escolas públicas e particulares), o AIE familiar, o AIE jurídico, o AIE político (o sistema político de que fazem parte 
os diferentes partidos), o AIE sindical, o AIE da informação (imprensa, rádio-televisão, etc.), o AIE cultural (Letras, Belas Artes, desportos, etc.). (ALTHUSSER, 1973, p. 43 - 44)

Para Althusser (1973, p. 46) "pouco importa que as instituições que os realizam sejam públicas ou privadas. O que importa é seu funcionamento. Instituições privadas podem perfeitamente funcionar como Aparelhos Ideológicos de Estado.” A diferença, segundo ele, é que enquanto os aparelhos repressivos do Estado funcionam através da violência, os Ideológicos funcionam pela ideologia. Neste sentido, o feminismo, na década de 1970, criticou os media como Aparelhos Ideológicos do Estado por contribuir com a manutenção das desigualdades de gênero. Para as feministas, se a classe social era um elemento estruturante nas relações sociais, a questão de gênero também era. Esse questionamento causou algumas rupturas nos Estudos Culturais, principalmente no que se refere ao conceito de poder. O que significava poder para os Estudos Culturais? As feministas trouxeram a subjetividade para a discussão cultural, ou seja, pautaram questões em torno da subjetividade e dos sujeitos. A discussão deixou de ser centrada apenas na classe social como estrutura fundamental de poder e, a partir dos Estudos Culturais, sob influência feminista, passou-se a levar em consideração outras categorias como gênero, raça, etnia e as subjetividades humanas que permeiam as relações sociais. Muitas pesquisas de abordagem feminista foram realizadas com base nesta tradição, como: A Woman's World: Women, ideology of femininity ${ }^{4}$, de Janice Winship (1978), que observou como as revistas femininas eram construídas de acordo com as fantasias e desejos masculinos. Gaye Tuchman (1978) organizou Heart and Images of Women in the Mass Media ${ }^{5}$, onde reuniu contribuições de acadêmicos sobre as representações da mulher na mídia. An Ideology of Adolescent Femininity ${ }^{6}$ (1982) de Angela MsRobbie e Valerie Walkerdine (1984) apresentou Someday my prince Will come $^{7}$, onde analisou a forma como os quadrinhos femininos preparavam as meninas para a heterossexualidade e o amor romântico. Tânia Modleski (1984) discutiu, em Loving with a Vengeance: Mass produced fantasies for women $^{8}$, as narrativas de novelas e romances femininos. Charlotte Brundson escreveu

\footnotetext{
${ }^{4}$ Uma mulher do mundo: Mulheres, Ideologia da Feminilidade (tradução nossa)

${ }^{5}$ Coração e imagens de mulheres nos meios de comunicação de massa (tradução nossa)

${ }^{6}$ Uma ideologia de feminilidade juvenil (tradução nossa)

${ }^{7}$ Um dia meu príncipe virá (tradução nossa)

${ }^{8}$ Amorosa como uma vingança: fantasias produzidas em massa para mulheres (tradução nossa)
} 
Crossroads: notes on soap opera ${ }^{9}$ (1991), Womem watching television $^{10}$ (1986) e Feminism and soap opera ${ }^{11}$ (1988). Estas pesquisas começam centradas no texto e no receptor e, com o passar dos anos, focam no estudo do receptor em relação com o contexto social. Janice Radway (1988) publica Reading the romance: womem, patriarchy and popular literature ${ }^{12}$. Carol Lopate, Tânia Modleski e Michèlle Mattelart escrevem Womem and the cultural industries ${ }^{13}$ (1982) e Womem, media and crisis: femininity and disorder ${ }^{14}$ (1986). Joke Hermes (1995), em Reading women's magazines: an analysis of everyday media uses $^{15}$, faz uma antropologia cotidiana de como as revistas se tornam significantes para as suas leitoras.

Os estudiosos de Birminghan introduziram um olhar diferente para a cultura, que passou a ser vista a partir da diversidade, ou seja, a abordagem culturalista reconhece a produção de cultura em todos os níveis sociais. Disso resulta a dificuldade, a priori, de seguir um marxismo ortodoxo, que entendia a cultura como produção exclusiva de uma elite, que a utilizava para a dominação ideológica das outras classes. Para o marxismo ortodoxo, a infraestrutura (o nível econômico) é um nível mais profundo, que produz e determina todos os outros da superestrutura (Estado, instituições políticas e cultura). É justamente nesse ponto que reside a discordância entre a linha culturalista e o marxismo ortodoxo.

Os cultural studies e o marxismo nunca se encaixaram na perfeição em momento algum. Desde o início (...), já pairava no ar a sempre pertinente questão das grandes insuficiências, teóricas e políticas, dos silêncios retumbantes, das grandes evasões do marxismo - as coisas de que Marx não falava nem parecia compreender, mas que eram o nosso objeto privilegiado de estudo: cultura, ideologia, o simbólico. (Hall, 1999, p. 68-69)

Portanto, devemos considerar a importância de observar a cultura de massa produzida pela sociedade moderna como marca fundamental de uma sociedade que passa a se universalizar, a interagir e a significar-se socialmente através das mensagens mediáticas. A tradição dos estudos culturais foi importante e continua sendo para observar o simbólico, o cultural, o que é transmitido e sustentado pela cultura, por meio

\footnotetext{
${ }^{9}$ Encruzilhada: Notas sobre uma novela (tradução nossa)

${ }^{10}$ Mulheres assistindo televisão (tradução nossa)

${ }^{11}$ Feminismo e novela (tradução nossa)

${ }^{12}$ Lendo o romance: mulheres, patriarcado e literatura popular (tradução nossa)

${ }^{13}$ Mulheres e indústria cultural (tradução nossa)

${ }^{14}$ Mulheres, mídia e crise: feminilidade e desordem (tradução nossa)

${ }^{15}$ Lendo revistas femininas: uma análise dos usos cotidianos da mídia
} 
da formulação da própria cultura de massa produzida, difundida e modificada pelos meios de comunicação.

Segundo Escosteguy:

Questões como raça e etnia, o uso e a integração de novas tecnologias como o vídeo e a TV, assim como seus produtos na constituição de identidades de gênero, de classe, bem como as geracionais e culturais, e as relações de poder nos contextos domésticos de recepção, continuam na agenda, principalmente das análises de recepção. (ESCOTEGUY, 2001, p. 37)

É no Brasil e nos países da América Latina onde vai haver uma predominância dos estudos de recepção e um cruzamento entre estes e os estudos culturais, a ponto de eles serem quase sinônimos. Para Itânia Gomes (2004), existe uma coincidência entre os dois, assim como na classificação estudos socioculturais, utilizada por Escosteguy e Jacks (2005), quando elas utilizam este termo para designar as pesquisas de Comunicação que têm uma perspectiva ampla do processo de recepção.

Recusamos a distinção entre as análises de recepção e os Estudos culturais porque entendemos que, rigorosamente, as análises de recepção são as investigações empíricas sobre a relação entre media e audiência realizadas dentro do quadro teórico-metodológico dos Estudos Culturais. (GOMES, 2004, p. 221)

Os Estudos Culturais latino-americanos são fortemente caracterizados pelos estudos de recepção e têm como objetivo central observar a cultura no processo de comunicação de massa, suas significações e ressignificações junto aos receptores, entendendo as mensagens mediáticas como um produto cultural capaz de elucidar o contexto das relações sociais. Trata-se de analisar o processo, produto e a mensagem da comunicação como formas da cultura e considerar que:

Pensar a comunicação na América Latina é cada dia mais uma tarefa de envergadura antropológica. Pois o que aí está em jogo não são só deslocamentos do capital e inovações tecnológicas, mas profundas transformações na cultura cotidiana das maiorias: mudanças que trazem à superfície estratos profundos da memória coletiva ao mesmo tempo em que movimentam imaginários que fragmentam e deshistoricizam. Mudanças que nos confrontam com uma acelerada desterritorialização das demarcações culturais e com desconcertantes hibridizações nas identidades. E, por mais escandaloso que pareça, é um fato que as massas na América Latina estão se incorporando à modernidade não pela mão do livro, não seguindo o projeto ilustrado, 
mas desde os formatos e os gêneros das indústrias culturais do audiovisual.[...] Esse é o cenário no qual se estabelecem hoje as relações entre comunicação e cultura: o da desestruturação das comunidades e da fragmentação da experiência, o da perda da autonomia do cultural e da mescla arbitrária das tradições, o da emergência de novas culturas que desafiam tanto a sistemas educativos incapazes de se encarregar do que os meios maciços significam e são culturalmente, como a políticas culturais dedicadas ainda majoritariamente a difundir e conservar." (MARTÍN- BARBERO, 2004, p. 209-210)

Portanto, pensar a comunicação na América Latina é pensar também as transformações na cultura das maiorias, as mudanças e também as continuidades e disso a necessidade de observar profundamente a atualidade como o resultado de um processo histórico que traz à tona a relação entre o fragmento do atual e a resistência da memória coletiva. Além do mais, é preciso compreender que a realidade latino-americana, de fato, tem sua peculiaridade, tendo feito outro caminho durante a modernidade, muitas vezes com sistemas de educação frágeis ou insuficientes, nos quais as relações com os media foram fundamentais no acesso a produtos culturais e informações. Isso torna nossa realidade singular no que se refere à significação dos meios de comunicação de massa.

Já em relação aos estudos de recepção de publicidade no Brasil podemos dizer que são escassos. Nos anos 1990, Jacks (2002) apresentou os números de pesquisa que elegeram a publicidade como tema, foram 1.789 trabalhos acadêmicos (teses $\mathrm{e}$ dissertações), sendo os estudos de recepção da publicidade apenas reduzidos a uma tese e duas dissertações. Conforme aponta Jacks e Piedras (2010), entre 2000 e 2009, foram defendidas 5.724 pesquisas de pós-graduação no Brasil e, dessas, 165 foram estudos de recepção, no entanto, apenas 16 envolviam recepção de publicidade, sendo 13 teses e 3 dissertações. Portanto, se somarmos as pesquisas de pós-graduação das últimas duas décadas, teremos 19 pesquisas, segundo Jacks e Piedras (2010), e mais uma dissertação concluída em 2012, por Santos, envolvendo estudos de recepção de publicidade. São elas:

\begin{tabular}{|l|l|l|l|}
\hline & Estudos de Recepção & Autor/ Ano & $\begin{array}{l}\text { Dissertação/ } \\
\text { Tese/ } \\
\text { Universidade }\end{array}$ \\
\hline
\end{tabular}




\begin{tabular}{|c|c|c|c|}
\hline 1. & $\begin{array}{l}\text { Quem tem medo da } \\
\text { propaganda? Estudo da reação } \\
\text { à propaganda através da } \\
\text { manifestação espontânea do } \\
\text { consumidor em Jornal de } \\
\text { Santos }\end{array}$ & (AUGUSTO, 1993); & $\begin{array}{l}\text { Tese de } \\
\text { doutorado - } \\
\text { Escola de } \\
\text { Comunicação } \\
\text { e Artes. } \\
\text { Universidade } \\
\text { de São Paulo. }\end{array}$ \\
\hline 2. & $\begin{array}{l}\text { A orgia dos objetos: Estudo } \\
\text { sobre recepção, publicidade e } \\
\text { "excluídos" }\end{array}$ & (MATOS, 1995); & $\begin{array}{l}\text { Dissertação de } \\
\text { Mestrado em } \\
\text { Comunicação. } \\
\text { Universidade } \\
\text { Federal da } \\
\text { Bahia. }\end{array}$ \\
\hline 3. & $\begin{array}{l}\text { Mais do que feijão com arroz: } \\
\text { Consumo, publicidade e } \\
\text { cultura no meio rural }\end{array}$ & (KESSLER, 1997); & $\begin{array}{l}\text { Dissertação de } \\
\text { Mestrado em } \\
\text { Comunicação } \\
\text { - Universidade } \\
\text { Metodista de } \\
\text { São Paulo. }\end{array}$ \\
\hline 4. & $\begin{array}{l}\text { Os jovens e a recepção da } \\
\text { publicidade televisiva }\end{array}$ & (MALDANER, 2000) & $\begin{array}{l}\text { Dissertação de } \\
\text { Mestrado em } \\
\text { Comunicação } \\
- \\
\text { Universidade } \\
\text { Metodista de } \\
\text { São Paulo. }\end{array}$ \\
\hline 5. & $\begin{array}{l}\text { A Propaganda Institucional } \\
\text { como formadora de atitude }\end{array}$ & (AZEVEDO, 2001) & $\begin{array}{l}\text { Dissertação de } \\
\text { Mestrado em } \\
\text { Comunicação } \\
\text { - Pontifícia } \\
\text { Universidade } \\
\text { Católica do } \\
\text { Rio Grande do } \\
\text { Sul }\end{array}$ \\
\hline 6. & $\begin{array}{l}\text { Ética na Propaganda sob o } \\
\text { olhar do consumidor e suas } \\
\text { significações: um estudo a } \\
\text { partir de denúncias } \\
\text { encaminhadas ao CONAR }\end{array}$ & (BRAGALIA, 2004) & $\begin{array}{l}\text { Dissertação de } \\
\text { Mestrado em } \\
\text { Comunicação } \\
- \\
\text { Universidade } \\
\text { Estadual do } \\
\text { Rio de Janeiro }\end{array}$ \\
\hline 7. & $\begin{array}{l}\text { Marginal ou invisível? A } \\
\text { representação de usuários de } \\
\text { drogas injetáveis nas } \\
\text { publicidades do Ministério da } \\
\text { Saúde }\end{array}$ & (SIQUEIRA, 2004) & $\begin{array}{l}\text { Dissertação de } \\
\text { Mestrado em } \\
\text { Comunicação } \\
- \\
\text { Universidade } \\
\text { de Brasília } \\
\end{array}$ \\
\hline
\end{tabular}




\begin{tabular}{|c|c|c|c|}
\hline 8. & $\begin{array}{l}\text { Mulher e publicidade: estudo } \\
\text { da produção e da recepção da } \\
\text { identidade da Mulher-Mãe na } \\
\text { mídia televisiva }\end{array}$ & (SILVA, 2002) & $\begin{array}{l}\text { Dissertação de } \\
\text { Mestrado em } \\
\text { Comunicação } \\
- \\
\text { Universidade } \\
\text { do Vale do } \\
\text { Rio dos Sinos }\end{array}$ \\
\hline 9. & $\begin{array}{l}\text { Mídia e identidade regional: } \\
\text { negociações da gauchidade na } \\
\text { recepção das propagandas } \\
\text { políticas no RS }\end{array}$ & (GUTBIER, 2003); & $\begin{array}{l}\text { Dissertação de } \\
\text { Mestrado em } \\
\text { Comunicação } \\
\text { - Unisinos - } \\
\text { Universidade } \\
\text { do Vale do } \\
\text { Rio dos Sinos }\end{array}$ \\
\hline 10 . & $\begin{array}{l}\text { As representações sociais do } \\
\text { receptor infantil de duas } \\
\text { escolas da cidade de São } \\
\text { Paulo, a partir de comercias } \\
\text { de TV }\end{array}$ & (YANAZE, 2005) & $\begin{array}{l}\text { Tese de } \\
\text { Doutorado em } \\
\text { Comunicação } \\
\text { - Escola de } \\
\text { Comunicações } \\
\text { e Artes da } \\
\text { Universidade } \\
\text { de São Paulo. }\end{array}$ \\
\hline 11. & $\begin{array}{l}\text { Publicidade, imaginário e } \\
\text { consumo: anúncios no } \\
\text { cotidiano feminino }\end{array}$ & (PIEDRAS, 2007) & $\begin{array}{l}\text { Tese de } \\
\text { Doutorado em } \\
\text { Comunicação } \\
\text { e Informação - } \\
\text { Pontifícia } \\
\text { Universidade } \\
\text { Católica do } \\
\text { Rio Grande do } \\
\text { Sul. }\end{array}$ \\
\hline 12. & $\begin{array}{l}\text { A comunicação das } \\
\text { campanhas sociais na } \\
\text { televisão: a leitura do jovem } \\
\text { sobre o referendo da } \\
\text { comercialização de armas de } \\
\text { fogo e munição no Brasil }\end{array}$ & (PAIXÃO, 2007); & $\begin{array}{l}\text { Dissertação de } \\
\text { Mestrado em } \\
\text { Comunicação } \\
- \\
\text { Universidade } \\
\text { Estadual de } \\
\text { São Paulo }\end{array}$ \\
\hline 13. & $\begin{array}{l}\text { Publicidade na "Terra do } \\
\text { Nunca": as relações entre } \\
\text { consumo, juventude e escolha } \\
\text { do curso de Publicidade e } \\
\text { Propaganda }\end{array}$ & (GOELLNER, 2007) & $\begin{array}{l}\text { Tese de } \\
\text { Doutorado em } \\
\text { Comunicação } \\
\text { e Informação } \\
- \\
\text { Universidade } \\
\text { Federal do Rio } \\
\text { Grande do Sul }\end{array}$ \\
\hline
\end{tabular}




\begin{tabular}{|c|c|c|c|}
\hline 14. & $\begin{array}{l}\text { O estímulo audiovisual na } \\
\text { comunicação publicitária da } \\
\text { marca Havaianas - um estudo } \\
\text { da recepção a partir da } \\
\text { diferenciação dos gêneros }\end{array}$ & (VINIC, 2008) & $\begin{array}{l}\text { Dissertação de } \\
\text { Mestrado em } \\
\text { Comunicação } \\
- \\
\text { Universidade } \\
\text { Paulista. }\end{array}$ \\
\hline 15. & $\begin{array}{l}\text { Comunicação publicitária } \\
\text { criativa, um estudo da } \\
\text { recepção sobre a peça “A } \\
\text { Semana” feita para a revista } \\
\text { Época }\end{array}$ & (PATARA, 2008) & $\begin{array}{l}\text { Dissertação de } \\
\text { Mestrado em } \\
\text { Comunicação } \\
- \\
\text { Universidade } \\
\text { Paulista. }\end{array}$ \\
\hline 16. & $\begin{array}{l}\text { Discurso publicitário como } \\
\text { dispositivo disciplinar: os } \\
\text { impactos da campanha "Real } \\
\text { Universitário" na recepção do } \\
\text { público jovem }\end{array}$ & (VAZ, 2008); & $\begin{array}{l}\text { Dissertação de } \\
\text { Mestrado em } \\
\text { Comunicação } \\
\text { e Práticas de } \\
\text { Consumo - } \\
\text { Escola de } \\
\text { Propaganda e } \\
\text { Marketing }\end{array}$ \\
\hline 17. & $\begin{array}{l}\text { A recepção pelos paulistanos } \\
\text { das mensagens midiáticas de } \\
\text { divulgação do turismo na } \\
\text { Bahia }\end{array}$ & (CARVALHO, 2009) & $\begin{array}{l}\text { Dissertação de } \\
\text { Mestrado em } \\
\text { Comunicação } \\
\text { e Práticas de } \\
\text { Consumo }- \\
\text { Escola de } \\
\text { Propaganda e } \\
\text { Marketing. }\end{array}$ \\
\hline 18. & $\begin{array}{l}\text { A estratégia publicitária } \\
\text { influenciada pelas lógicas de } \\
\text { consumo }\end{array}$ & (SANTOR, 2009) & $\begin{array}{l}\text { Dissertação de } \\
\text { Mestrado em } \\
\text { Comunicação) } \\
- \\
\text { Universidade } \\
\text { Federal de } \\
\text { Santa Maria } \\
\end{array}$ \\
\hline 19. & $\begin{array}{l}\text { Publicidade autorreferencial } \\
\text { do Diário Gaúcho: } \\
\text { encenações do produto } \\
\text { midiático e do leitor }\end{array}$ & DEPEXE, 2009 & $\begin{array}{l}\text { Dissertação de } \\
\text { Mestrado em } \\
\text { Comunicação } \\
- \\
\text { Universidade } \\
\text { Federal de } \\
\text { Santa Maria. }\end{array}$ \\
\hline
\end{tabular}




\begin{tabular}{|l|l|l|l|}
\hline 20. & $\begin{array}{l}\text { Masculinidade em anúncio } \\
\text { (s): recepção publicitária e } \\
\text { identidade de gênero. }\end{array}$ & (SANTOS, 2012). & Dissertação de \\
& & & Mestrado em \\
& & & - \\
& & & Universidade \\
& & Federal de \\
& & Santa Maria \\
\hline
\end{tabular}

Tabela 2. - Revisão de Literatura Estudos Culturais ${ }^{16}$

Dessas pesquisas, as que abordam a categoria de gênero são quatro: Mulher e publicidade: estudo da produção e da recepção da identidade da Mulher-Mãe na mídia televisiva (SILVA, 2002); Publicidade, imaginário e consumo: anúncios no cotidiano feminino (PIEDRAS, 2007); O estímulo audiovisual na comunicação publicitária da marca Havaianas: um estudo da recepção a partir da diferenciação dos gêneros (VINIC, 2008); Masculinidade em anúncio (s): recepção publicitária e identidade de gênero. (SANTOS, 2012).

Esse número reduzido de pesquisas que relacionam publicidade, recepção e gênero demonstra que nossa pesquisa pode contribuir também para a geração de dados nesta perspectiva de estudo.

Neste sentido, os estudos de recepção e a tradição dos estudos culturais latinoamericanos se tornam um aporte teórico-metodológico interessante para olhar nosso objeto de estudo, levando em consideração que hoje os desafios são ainda maiores com o advento da internet e a sincronização das mensagens no dia a dia dos sujeitos, a todo instante.

\section{Gêneros construídos}

Foram de fundamental importância os estudos acadêmicos que desconstruíram o determinismo biológico como elemento definidor das diferenças entre homens e mulheres e apresentaram a perspectiva da construção social dos gêneros. Segundo Saffioti:

É de extrema importância compreender como a naturalização dos processos socioculturais de discriminação contra a mulher e outras

\footnotetext{
${ }^{16}$ Tabela baseada em informações fornecidas por Jacks (2002) e Santos (2012).
} 
categorias sociais constitui o caminho mais fácil e curto para legitimar a "superioridade" dos homens, assim como a dos brancos, a dos heterossexuais, a dos ricos. (SAFFIOTTI, 1987, p. 11)

A inferioridade da mulher e os papéis sociais divididos entre homens e mulheres passaram a ser questionados quando as mulheres, ainda no século XIX, lutaram pelo acesso à cidadania, traduzidas em reivindicações por mudanças no sistema de educação requerendo o direito ao estudo, assim como o direito ao voto e ao trabalho. Todo esse processo de mudanças sociais, econômicas e políticas acontecem em meio à Revolução Francesa e culminam com a I Guerra Mundial, em 1914, provocando transformações imensas na sociedade. Nessa conjuntura, as mulheres ingressam no mercado de trabalho, mas permanecem tendo direitos desiguais e ainda reduzidos, além de acumularem as tarefas domésticas e de cuidado com os filhos.

A identidade social da mulher, assim como a do homem, é construída através da atribuição de distintos papéis, que a sociedade espera ver cumpridos pelas diferentes categorias de sexo. A sociedade delimita, com bastante precisão, os campos em que pode operar a mulher, da mesma forma como escolhe os terrenos em que pode atuar o homem. (SAFFIOTTI, 1987, p. 08).

Essa divisão sexual do trabalho criou e determina até hoje os lugares sociais em que homens e mulheres podem atuar, agir e assumir.

Os estudos sobre gênero no Brasil surgem com as correntes feministas no ano 1970. Primeiramente é preciso reconhecer que existem várias dessas correntes, no entanto, apesar de divergirem em algumas perspectivas, todas concordam num ponto: crítica ao pensamento binário (ARRUDA, 2002). Para entender melhor essas relações de gênero presentes na sociedade e que se refletem nos produtos mediáticos, vamos apresentar algumas abordagens sobre gênero, corpo e sexualidade, esta última relacionada ao discurso religioso.

Os estudos feministas foram fundantes da premissa de que os gêneros são socialmente construídos, e não biologicamente determinados.

Ao dirigir o foco para o caráter "fundamentalmente social, não há, contudo, a pretensão de negar que o gênero se constitui com ou sobre corpos sexuados, ou seja, não é negada a biologia, mas enfatizada deliberadamente, a construção social e histórica produzida sobre as características biológicas [...] Pretende-se, desta forma, relocar o debate no campo do social, pois é nele que se constroem e se reproduzem as relações (desiguais) entre os sujeitos. As justificativas para as desigualdades precisariam ser buscadas não nas diferenças biológicas (se é que mesmo essas podem ser compreendidas fora de sua constituição social), mas sim nos arranjos sociais, na história, nas 
condições de acesso aos recursos da sociedade, nas formas de representação. (LOURO, 1997, p. 20 -21)

Joan Scott (1995) se interessa pelos significados sociais dados às diferenças sexuais e chama atenção para o fato de os gêneros fazerem parte de uma construção histórica, portanto reflete sobre a necessidade de utilizar gênero como uma categoria analítica e critica a necessidade de sair do binarismo homem/mulher, masculino/feminino.

Minha definição de gênero tem duas partes e diversas subpartes. Elas são ligadas entre si, mas deveriam ser distinguidas na análise. O núcleo essencial da definição repousa sobre a relação fundamental entre duas proposições: o gênero é um elemento constitutivo de relações sociais fundadas sobre as diferenças percebidas entre os sexos, e o gênero é um primeiro modo de dar significado às relações de poder. As mudanças na organização das relações sociais correspondem sempre a mudanças nas representações do poder, mas a direção da mudança não segue necessariamente um único sentido. (SCOTT, 1990, p.14)

Michelle Perrot (2003) reflete sobre a exibição do corpo feminino nos espaços públicos e diz ser a beleza da mulher um capital simbólico que o homem rico gosta de ostentar.

[...] constitui um capital simbólico a ser barganhado no casamento ou no galanteio. O homem rico gosta de ostentar a beleza de sua(s) amante(s): um luxo que ele se pôde permitir e que lhe glorifica a virilidade. (PERROT, 2003, p. 14)

A filósofa Judith Butler, inspiradora da vertente Queer, critica as análises feministas que trabalham com a categoria de gênero, porque segundo a autora, a definição de gênero fundamentada a partir do sexo dos sujeitos seria em si mesma uma designação heteronormativa. Ela diz que a história social não pode ser construída apenas para o gênero, que o sexo também pode ser construído socialmente e que o fato de assegurar a categoria sexo no campo biológico, da natureza, determina ao corpo um gênero, o que demonstra uma ordem compulsória entre sexo, gênero e desejo.

O gênero não deve ser meramente concebido como a inscrição cultural de significado num sexo previamente dado [...] tem de designar também o aparato mesmo de produção mediante o qual os próprios sexos são estabelecidos. (BUTLER, 2010, p. 25).

Essa perspectiva de Butler tem sido bastante utilizada para o desmonte da heteronormatividade, a partir da teoria Queer e de estudos sobre travestis e transexuais. 
Já Raewyn Connell (1995) publica Masculinities onde reflete sobre a construção social da masculinidade e desenvolve o conceito de masculinidade hegemônica, que seria um conjunto de práticas exercidas tanto por homens, como por mulheres que legitimam o patriarcado e garante tanto em nível local, quanto global a subordinação das mulheres pelos homens. Connel abre as portas para uma conceituação de gênero multidimensional, na qual as práticas se estabelecem não pelas diferenças entre homens e mulheres, mas pelas relações sociais atribuídas aos corpos. Para ela "Gênero é a estrutura das relações sociais que se centra na arena reprodutiva [...] e a configuração de práticas que trazem as distinções reprodutivas entre os corpos para os processos sociais." (CONNEL, 2009, p. 11). No entanto, sua grande contribuição foi sobre o estudo das masculinidades, afirmando que a narrativa convencional adota apenas um modelo de masculinidade e enxerga o gênero como um molde cuja marca é deixada desde criança. Além disso, a narrativa convencional apresenta a masculinidade como um projeto individual, o que Connel (2000) critica dizendo que essa narrativa dá conta da masculinidade hegemônica, mas por outro lado não considera que existem múltiplas masculinidades. Para Nolasco (1997) trata-se da construção da ideia de um homem de verdade que é calcada no seu papel social de ser viril e conquistador, ter sucesso, poder e prestígio social. Por outro lado, o preço é alto os homens crescem achando que existe um modo de ser homem de verdade e todos os outros modos que não são, portanto todas as formas de ser homem de verdade, conseguem nunca fracassar, sempre vencer e dominar, para que não venham a ter a chamada masculinidade problemática.

[...] para todo homem de verdade existem muitos outro que não o são. O macho e a bicha, o bem-sucedido e o fracassado, o forte e o fraco, o público e o doméstico são polaridades que servem para demarcar uma noção de masculinidade problemática. (NOLASCO, 1997, p. 24).

Dialogando mais com o que pensamos se insere Heleieth Saffioti, que também dialoga com Connel, no sentido de afirmar a necessidade de, ao pensar em gênero, relacioná-lo com patriarcado. Saffioti (2004) critica a categoria gênero ao dizer que esta está esvaziada politicamente, pois ao conceituar gênero, descola-se as relações sociais de poder que estão imbricadas às de gênero e, portanto, ela recomenda que, ao pensar gênero, seja considerada a categoria patriarcado, um conceito histórico que permite colocar em debate a ordem patriarcal de gênero. Para Saffioti, utilizar apenas o 
conceito de gênero não atacaria a raiz da dominação dos homens sobre as mulheres. (SAFFIOTI, 2004, p. 136).

Já para Connel (2013), que também articula o patriarcado na sua definição de masculinidade, e dentre elas a hegemônica e as outras, que seriam as múltiplas, dominadas internamente pela masculinidade hegemônica, a masculinidade hegemônica não é autoreprodutora nem pelo habitus, como acredita Bourdieu, nem por outros mecanismos, pois:

Para se sustentar um dado padrão de hegemonia é necessário o policiamento de todos os homens, assim como a exclusão ou o descrédito das mulheres. Evidências de tais mecanismos variam do descrédito de opções "soft" num mundo de relações internacionais "hard", desde as ameaças à segurança e à guerra, a violências e assassinatos homofóbicos, chegando a constrangimentos de meninos nas escoladas por "bichices". (CONNEL, 2013, p. 260)

Desse modo, Connel evidencia o problema da masculinidade como um problema de hegemonia, controle e domínio de alguns homens sob outros que se aproximem da feminilidade e sobre as mulheres.

Pierre Bourdieu (2002) também pensou sobre A Dominação Masculina, nome de seu livro, segundo o qual esta dominação está presente no pensamento, nos corpos, nos símbolos e na linguagem dos seres humanos. No entanto, sua perspectiva de análise nos remete a Scott (1995) e a Butler (2010), por exemplo, quando ele diz que se trata de uma relação arbitrária de domínio:

O mundo social constrói o corpo como realidade sexuada e como depositório de princípios de visão e de divisão sexualizantes. Esse programa social de percepção incorporada aplica-se a todas as coisas do mundo e, antes de tudo, ao próprio corpo, em sua realidade biológica: é ele que constrói a diferença entre os sexos biológicos, conformando-a aos princípios de uma visão mítica do mundo, enraizada na relação arbitrária de dominação dos homens sobre as mulheres, ela mesma inscrita, com a divisão do trabalho, na realidade da ordem social. (BOURDIEU, 2002, p. 20)

Nos estudos de beleza, Vigarello (2006) resgata a história da beleza feminina desde o século XVI até hoje e apresenta 3 significações para a beleza feminina na Europa: a do Século XVI, caracterizada pelo predomínio dos rituais estéticos da nobreza; a do século XVII, pelo alto do corpo como rosto, mãos, busto; e a do fim do 
século XIX, pela importância do baixo corpo e pelo encurtamento das roupas. Bakhtin retrata sobre os baixos e os altos corporais da população na Idade Média e no Renascimento e, apesar de não se referir especificamente às mulheres, contribui para pensarmos a relação com o corpo na época. Se no grotesco o corpo é desproporcional e representa a mistura entre humano e natureza, é um corpo mais coletivo do que individual, na modernidade isso muda significativamente (BAKHTIN, 2008).

Em oposição aos cânones modernos, o corpo grotesco não está separado do resto do mundo, não está isolado, acabado nem perfeito, mas ultrapassa-se a si mesmo, franqueia seus próprios limites. Colocase ênfase nas partes do corpo em que ele se abre ao mundo exterior, isto é, onde o mundo penetra nele ou dele sai ou ele mesmo sai para o mundo, através de orifícios, protuberâncias, ramificações e excrescências, tais como a boca aberta, os órgãos genitais, seios, falo, barriga e nariz. (BAKHTIN, 2008, p. 23).

Bakhtin apresenta o corpo grotesco como inacabado, aberto e que confunde animais e humanos, um corpo em movimento, exagerado. Ele também reflete sobre os baixos e altos corporais no grotesco da Idade Média e no período do Renascimento.

O "alto" e o "baixo" possuem aí um sentido absoluta e rigorosamente topográfico. O "alto" é o céu; o "baixo" é a terra; a terra é o princípio de absorção (o túmulo, o ventre) e, ao mesmo tempo, de nascimento e ressurreição (o seio materno). Este é o valor topográfico do alto e do baixo no seu aspecto cósmico. No seu aspecto corporal, que não está nunca separado com rigor do seu aspecto cósmico, o alto é representado pelo rosto (a cabeça) e o baixo pelos órgãos genitais, o ventre e o traseiro. (BAKHTIN, 2008, p. 18 -9).

No entanto, o baixo e o alto se completam, misturam-se, são uma única coisa. A ligação é ambivalente, o baixo corporal representa vida através do coito, da gravidez, do corpo e da terra. Dessa maneira, o baixo corporal se torna o inferior positivo que se renova e renasce. Esse sentido uno entre baixo e alto se fragmenta nos séculos XVII e XVIII.

Em relação ao corpo no Brasil, no livro História das Mulheres no Brasil, 2006, o autor do capítulo Eva Tupinambá, Ronald Raminelli, aponta como as índias tupinambás lidavam com a nudez de seus corpos de uma maneira natural, e não luxuriosa, apesar da nudez, enquanto as europeias do século XVI, com suas vestes e ornamentos, incitavam muito mais a luxúria (RAMINELLI, 2006). 
Evidentemente, a relação com os corpos entre as índias tupinambás, até então, não havia sofrido influência do branco europeu e do discurso da Igreja, peça fundamental para entender o controle dos corpos e da sexualidade, pois: "A todopoderosa Igreja exercia forte pressão sobre o adestramento da sexualidade feminina. $\mathrm{O}$ fundamento escolhido para justificar a repressão da mulher era simples: o homem era superior, e portanto cabia a ele exercer a autoridade.” (ARAÚJO, 2006, p. 45- 46). $\mathrm{O}$ pecado do Éden era relembrado às mulheres o tempo todo e por consequência a mulher estava condenada a pagar pelo erro de Eva.

Ao contextualizar historicamente a sexualidade feminina na colônia, Araújo (2006) evidencia o programa de estudos destinado às meninas, que limitava o aprendizado ao máximo, diferentemente dos meninos e que:

No conjunto, o projeto educacional destacava a realização das mulheres para o casamento, tornando-as afinal hábeis na "arte de prender a seus maridos e filhos como por encanto, sem que eles percebam a mão que os dirige e nem a cadeia que os prende". Em outras palavras, devia-se aguçar seu instinto feminino na velha prática da sedução, do encanto. (ARÁÚJO, 2006, p. 51)

O discurso médico que vigorava entre os séculos XVI e XVIII, aliado ao da Igreja, sustentavam a imagem do corpo feminino como a casa onde Deus e o Diabo moravam.

Qualquer doença, qualquer mazela que atacasse uma mulher, era interpretada como um indício da ira celestial contra pecados cometidos, ou então era diagnosticada como sinal demoníaco ou feitiço diabólico. Esse imaginário que tornava o corpo um extrato do céu ou do inferno, constituía um saber que orientava a medicina e supria provisoriamente as lacunas de seus conhecimentos. (DEL PRIORE, 2006, p. 78)

Os mistérios que existiam em torno do corpo feminino, sobre a concepção e toda a especulação das doenças ligadas à menstruação, levavam a medicina a explicar fatores biológicos com discurso religioso, relacionando os mistérios da mulher com a loucura. Nesta época, o discurso médico só enxergava a vocação materna da mulher.

O empenho em normatizar o funcionamento da madre significava, além de adestrá-lo na via da maternidade, esvaziá-la de qualquer significado mágico, diabólico e enfeitiçador. Nessa época, acreditavase que o útero, oco de semente, tornava-se encantado e sedutor, capaz de criar com seus poderosos excretos todo o tipo de feitiço. (DEL PRIORE, 2006, p. 100) 
Já durante o século XIX, com a consolidação do capitalismo, as relações sociais sofrem mudanças significativas, a constituição da família, então burguesa, e das cidades urbanas provocaram modificações importantes para a vida das mulheres. $\mathrm{O}$ casamento passou a ser utilizado como um mecanismo de ascensão social e as mulheres cumpriam um papel fundamental neste processo, responsáveis pela boa conduta da família e empenhadas em contribuir para o projeto de ascensão social da família. O casamento arranjado pela família era prática comum e visava elevar o status familiar. Muitas mulheres conheciam seus maridos apenas na noite do casamento e um dos requisitos para um bom casamento era a virgindade, que "funcionava como um dispositivo para manter o status da noiva como objeto de valor econômico e político, sobre o qual se assentaria o sistema de herança de propriedade que garantia linhagem da parentela." (D’INCAO, 2006, p. 235).

Como as relações burguesas se aprofundaram e o capitalismo também, deu-se início a um processo de insatisfação das mulheres com a reduzida cidadania que possuíam. Esse fato tornou-se visível ao final do século XIX e durante a Segunda Guerra Mundial, quando as mulheres se viram diante da oportunidade de entrar no mundo do trabalho e, com isso, as contradições se acirraram. Modificaram-se as relações entre os gêneros e as mulheres assumiram alguns espaços públicos, questionando inclusive práticas de namoro e casamento. Esta época culmina com a organização dos movimentos feministas, que questionaram a naturalização da diferença entre os sexos e apontaram as desigualdades a que eram submetidas mulheres e homens.

Nesta relação entre gênero, sexualidade e corpo, também recebemos as contribuições de Foucault, que, ao pensar o corpo na publicidade, diz que exploram a erotização.

Como resposta à revolta do corpo, encontramos um novo investimento que não tem mais a forma de controle-repressão, mas de controleestimulação: fique nu, mas seja magro, bonito, bronzeado! (FOUCAULT, 1992, p. 142).

A esse respeito, a dissertação Culto ao corpo na publicidade, de Caio Milito, traz análise de sessenta e duas peças publicitárias coletadas de julho a dezembro de 2011, durante a programação da rede de televisão aberta como Globo, SBT, Rede TV, MTV, Bandeirantes, Record, nas quais o corpo tinha presença marcante. O autor afirma que: 
As distinções de gênero no corpus desta pesquisa apontam para uma maior superioridade no número de produtos oferecidos para as mulheres. $\mathrm{O}$ culto ao corpo e as diferentes práticas a ele relacionadas parecem ser direcionados mais especificamente ao público feminino. Das sessenta e duas propagandas analisadas, apenas cinco oferecem produtos destinados aos homens, sendo que dezenove delas destinamse a ambos. Trinta e oito peças publicitárias são destinadas ao público feminino. (MILITO, 2002, p. 52)

Ainda sobre a pesquisa de Milito (2012, p. 71) ele conclui que os modelos de masculinidade e feminilidade representados na publicidade estão de acordo com os papéis femininos e masculinos tradicionais compartilhados pelo senso comum e que em dezenove peças publicitárias aparecem indícios de que haja relacionamento amoroso entre personagens masculinos e femininos.

Já a tese de Iara Beleli, Marcas da diferença na propaganda brasileira, analisou "como a publicidade, ao evocar as diferenças de sexo, de gênero, de "raça" e de práticas sexuais delineia construções de gênero, sexualidade, de "raça" e de nacionalidade". (BELELI, 2005, p. 5). A autora definiu como corpus de pesquisa 28 anuários do Clube de Criação de São Paulo (CCSP), de 1975 a 2003, elegendo como objeto de sua observação a publicidade publicada em revistas e veiculadas em outdoos premiadas pelo CCSP. Ao analisar as campanhas de cerveja, que é o objeto de nosso estudo, Belili diz que:

[...] a "sensualidade da mulher brasileira" é associada a movimentos da cultura nacional - modernismo, bossa nova, tropicália, sambas enredo do Carnaval carioca e paulista, futebol. Na década de 70, Caetano Veloso e Chico Buarque cantaram "mesmo com toda fama, com toda Brahma, com toda cama, com toda lama, a gente vai levando essa chama...", revelando a marca/logo como elemento do cotidiano brasileiro. A imagem da "mulher bonita e sensual", justaposta às distintas marcas de cerveja, funciona como a identificação proposta ao consumidor. De um lado, comprar determinada cerveja potencializa o consumidor a conquistar aquela "linda mulher", de outro, ela seria o chamado para a marca/logo que se faz lembrar sempre, e este é o principal interesse do publicitário - criar um consumidor em potencial.” (BELILI, 2005, p. 129).

Ela cita a campanha da Kaiser veiculada em abril de 2003, que traz Daniela Cicarelli como garota propaganda, e critica a associação presente na peça ao se referir à modelo como marca natural do Brasil.

A relação entre a sociedade e o produto cultural, no nosso caso a publicidade de cerveja, trazem à tona as relações de gênero na sociedade e as permanências e 
rupturas das significações no processo sociocultural. Para isso, precisamos entender mais sobre a linguagem e o discurso publicitário que vamos analisar.

\section{Publicidade: Discurso, linguagem e criatividade.}

\subsection{Discurso}

Muitas pesquisas que estudam como as mulheres são representadas nas peças publicitárias acabam por listar uma série de críticas, principalmente por evidenciar uma mulher objeto. No entanto, o que nos parece interessante é perceber que não é fácil criticar o sistema ideológico da publicidade, principalmente porque quando uma parcela significativa da audiência sabe que: “(...) estaba siendo engañada y explotada, pero el hecho era que me sentía atraída" (Williamson, 1976:9)”. (Matellart, 2007, p. 37) ${ }^{17}$. Talvez esse seja um dos motivos de entrega diante das peças publicitárias, saber que se trata mesmo de um ideal a ser obtido, de um: " como seria bom se fosse verdade". León (2008), nos ajuda a entender este aspecto da publicidade:

[...] e essa é uma das facetas mais propriamente míticas, contraditórias para o campo da publicidade: a exibição, a falta de tramóia, a evidência, que por ser evidência não se deve analisar, não envolve nenhuma cultura especial, nenhuma gnose particular. Mas é uma transparência como saber nato, como irrelevância cognitiva e resulta na estratégia oculta. Mensagens evidentes: enquanto todo mundo crê saber o que é publicidade, uma mensagem que pretende vender, o que de tão óbvio inutiliza os procesos refelexivos. (LEÓN, 2008 , p. 26, tradução nossa) ${ }^{18}$

Segundo León (2008) é importante perceber que a publicidade pode e deve ser analisada pela ótica da mitoanálise e sua relação intrínseca com os mitos pelo fato de centrar forças nas narrativas, assim como no mito e também porque a publicidade não tem compromisso com a veracidade, trabalhando com um imaginário sobre-humano.

\footnotetext{
17 "Sabia que estava sendo enganada e explorada, mas me sentia atraída... (Williamson, 1976:9)". (Matellart, 2007, p. 37)

18 [...]y ésa es una de las facetas más propriamente míticas, contradictorias hasta la médula dela publicidad: a exibición, la falta de tramoya, la evidencia, que por ser evidencia no debe analizarse, no encierra ninguna cultura especial, ninguna gnosis particular. Pero es una transparencia como saber fatuo, como irrelevancia cognitiva, y resulta a la vez estrategia oculta. Mensajes evidentes: mientras todos creen saber qué es publicidad, un mensaje que pretende vender, lo que de puro obvio inutiliza los resortes reflexivos. (LEÓN, 2008, p. 26)
} 
A publicidade não somente porque faz uso das histórias míticas para contar suas narrativas e compor os seus personagens, mas porque ela mesma exerce hoje uma função mítica na sociedade contemporânea, misturando sonho e realidade, propondo e apresentando soluções aos problemas.

Esse é um ponto interessante para reflexão. No entanto, o discurso da publicidade é claro, o principal objetivo é vender. A realidade muitas vezes é bem diferente do que é mostrado pelas peças publicitárias, mas mesmo assim somos envolvidos e nos sentimos atraídos pela linguagem apresentada. Assim como um breve sonho perfeito, onde não existem conflitos sociais, e há sempre um final feliz.

Se, por um lado, a linguagem publicitária é envolvente, por outro, não podemos esquecer que é uma narrativa do mundo atual, que ajuda a compreender o mundo ao redor através da dinâmica, nesta pesquisa, dos vídeos publicitários de 30 ou 60 segundos veiculados na televisão brasileira. Isso também a caracteriza como um produto da cultura, pois, assim como afirma Moscovisci (1983, p. 156): “A cultura é criada pela e através da comunicação; e os princípios organizacionais da comunicação refletem as relações sociais que estão implícitas neles".

Portanto, o discurso da publicidade não pode ser acusado de enganar, fazer tramoia ou jogo sujo (LÉON, 2008), pelo fato de trabalhar, através da relação mítica intrínseca a sua linguagem, a dimensão lúdica e poética dos desejos e sonhos humanos.

As marcas de culto e os personagens publicitários são míticos sempre quando representam uma grandeza através de objetos ou seres que representam algo que intrínsecamente é impossível que sejam ou tenham, um poder, uma condensação de anseios de supremacía e perfeição. Neste sentido é o material perfeito para a religiosidade pósmoderna; socialmente não se elimina simplesmente a divindade, somente se transforma seu ser e seus dons para objetos da materialidade cotidiana, que passam a ser assim sagrados e míticos. (LEÓN, 2008, p. 25, tradução nossa) ${ }^{19}$

Já a presença de uma linguagem sarcástica e cheia de humor, dá ao receptor uma sensação de distanciamento das situações narradas pela publicidade, e também de ambiguidade, deixando a cargo dos receptores a missão de interpretação da mensagem

\footnotetext{
${ }^{19}$ Las marcas de culto y los personajes publicitarios son míticos siempre en cuanto representan una grandeza a través de objetos o seres que representan algo que intrínsecamente es imposible que sean o tengan, un poder, una condensación de anhelos de supremacía y perfección. En este sentido son el material perfecto para la religiosidad posmoderna; socialmente no se elimina simplemente a la divinidad, solamente se transmuta su ser y sus dones hacia objetos de la materialidad cotidiana, que pasan a ser así sacramentales míticos. (LEÓN, 2008, p. 25)
} 
em aberto, que pode ser lida ao pé da letra ou como passatempo. Não importa de a peça publicitária mostra um cabelo rebelde se transformar em liso, ou num homem magro se transformar em forte e másculo ao consumir produto $\mathrm{X}$ ou $\mathrm{Y}$, o que importa são as narrativas capazes de transformar homens e mulheres numa dimensão de deuses e semideuses capazes de brincar com a condição humana e se transformar em um encontro entre o poder sobre-humano e a fragilidade demasiadamente humana. Por isso a publicidade é uma "grande ferramenta para o estudo projetivo de nossas sociedades". (León, 2008, p.35)

Neste sentido, entender o discurso da publicidade é entender um pouco de nossa sociedade, principalmente da relação social entre os meios de comunicação e as pessoas. Peça fundamental para entender como funciona a sociedade capitalista e estabelecer conexões entre o individualismo e o consumo.

Como tem assinalado Pascal Bruckner (2003:133): “o capitalismo como cultura estimula e acompanha o individualismo, que adota seus ritmos e se beneficia de sua agilidade e flexibilidade". Além disso, há casos de ataques ao mundo dos negócios por (entre outras razões) o enfoque do capitalismo para a riqueza e o individualismo (Sproule, 2005: 117-118). Embora, desde o próprio pensamento liberal, se tem tentado dissociar mercado e individualismo. (Rodríguez Braun, 2000: 31) (PINEDA, 2008, p. 48, tradução nossa) ${ }^{20}$

Ou seja, a publicidade é uma consequência da economia capitalista. Em relação aos fatores que influenciam no individualismo publicitário, Pineda (2008, p. 47) cita quatro: a matriz capitalista (econômico), a influência dos Estados Unidos (como fator histórico), o pensamento da Nova Direita capitalista (fator ideológico) e a ressonância do individualismo na era pós-moderna como fator cultural.

E é justamente esse encontro entre fatores presentes na publicidade que fazem deste objeto da comunicação, uma interessante ferramenta para entender a sociedade em que vivemos.

Para Lipovetsky (1993, p.11) a cultura pós-moderna reforça o individualismo, porque atomiza os seres e anula seus pontos de referências ao trabalhar a fragmentação baseada na personalização e individualização. O capitalismo de consumo seria um bom

${ }^{20}$ Como ha señalado Pascal Bruckner (2003:133): <<El capitalismo como cultura estimula y acompanha al individualismo, que adopta sus ritmos y se beneficia de su agilidade y flexibilidade $>$. Además, hay casos de ataques al mundo de los negócios por (entre otras razones) el enfoque del capitalismo hacia la riqueza y el individualismo (Sproule, 2005: 117-118). Y aunque, desde el próprio pensamento liberal, se haya intentado dissociar mercado e individualismo (Rodríguez Braun, 2000: 31) (PINEDA, 2008, p. 48) 
exemplo disso, incentivando uma cultura individualista, que trabalha na direção da diferenciação e fragmentação dos desejos, distanciando a todos de qualquer projeto unitário de sociedade.

Da mesma maneira que os ideais universais da era moderna cedem seu lugar aos múltiplos e flutuantes vocês da pós-modernidade, se desvanecem as esperanças de se atender a uma única forma de ser ou a um cosmo unificado (LIPOVETSKY, 1997, p. 111, tradução nossa) ${ }^{21}$

Assim, segundo Pineda (2008), a publicidade se inscreve num ambiente cultural e ideológico que contribui para a eliminação das ideias de coletivo e social, pois: "La publicidade comercial está protagonizada em su mayoría por sujeitos aislados que persiguen sus fines individuales associando su pensamento o su conducta al produto o servicio publicitado".(Pineda, 2008, p. 57- 58).

Desse modo, a publicidade, mesmo que apresente situações coletivas, busca conduzir os receptores à satisfação pessoal, de modo que a mensagem proporcione experiências individuais em primeiro plano no que se refere à imagem, à aparência, ao modo de ser, ao estilo de vida.

Assim:

As diversas formas da cultura veiculadas pela mídia induzem os
indivíduos a identificar-se com as ideologias, as posições e as
representações sociais e políticas dominantes. Em geral, não é um
sistema de doutrinação ideológica rígida que induz à concordância
com as sociedades capitalistas existentes, mas sim os prazeres
propiciados pela mídia e pelo consumo. (KELLNER, 2001, p.11)

A publicidade, portanto, não vende somente produtos, mas também estilos de vida e identidades que, associados aos produtos, integram "construtos simbólicos com os quais o consumidor é convidado a identificar-se para tentar induzi-lo a usar o produto anunciado" (KELLNER, 2001, p. 324). No entanto, ao fornecer modelos de identidade, ela - pelo menos aparentemente - soluciona conflitos e contradições sociais, mantendo a ordem social vigente, trabalhando como o mito, do qual já tratamos anteriormente.

E é assim que a propaganda, a moda, o consumo, a televisão e a cultura da mídia estão constantemente desestabilizando identidades e contribuindo para produzir outras mais instáveis, fluidas, mutáveis e variáveis no cenário contemporâneo. No entanto, também vemos em funcionamento os implacáveis processos de mercadorização. A

\footnotetext{
${ }^{21}$ De la misma manera que los ideales universales de la era moderna ceden su lugar a las múltiples y fluctuantes vocês de la posmodernidad, se desvanecen las esperanzas de atenerse a uma sola forma de ser o a um cosmos unificado (LIPOVETSKY, 1997, p. 111)
} 
segmentação do mercado em diversas campanhas e apelos publicitários reproduz e intensifica a fragmentação, desestabilizando as identidades às quais os novos produtos e as novas identificações estão tentando devolver estabilidade. Portanto, o próprio capital é o demiurgo da alegada fragmentação pós-moderna, da dispersão de identidades, das mudanças e da mobilidade. Contrariando o que dizem Baudrillard (1976) e outros - que a pós-modernidade constitui uma ruptura com o capital e com a economia política -, o que detectamos por trás dos fenômenos de cultura pós-moderna é a lógica do capital. (KELLNER, 2001, p. 329).

E é dentro da lógica do capital e do sistema de mercado e consumo que a publicidade constrói sua linguagem, enviando mensagens objetivas, ao mesmo tempo em que trabalha na dimensão simbólica dos sonhos, desejos e carências humanas.

\subsection{Linguagem Publicitária}

A linguagem publicitária reúne diversas funções da linguagem e tem como objetivo passar uma mensagem clara, mas que, no contexto comercial, tem uma meta final estabelecida, a venda do produto referido.

A mensagem publicitária tem uma função comercial, cuja finalidade é divulgar e vender produtos ou serviços. É criada sob encomenda e produzida por profissionais que atuam em conjunto ou isoladamente em diferentes momentos de sua produção. $\mathrm{Na}$ criação de uma mensagem publicitária, tudo é meticulosamente planejado, ou seja, pensado para obter uma resposta do consumidor, traduzida em vendas. (HOFF, GABRIELLI, 2004, p. 02)

Vários elementos da linguagem estão presentes na mensagem publicitária, como humor e ambiguidade, mas sem perder o foco na objetividade. Segundo Nelly de Carvalho (2002), a ambiguidade mais comum na publicidade é o uso de homônimos palavras que possuem mesma grafia, mas têm sentidos diferentes - e a polissemia, palavras com vários significados. "É a inserção da palavra no contexto, aliada, no caso da publicidade, à associação com a imagem e com o nome da marca, que dá a chave do sentido." (CARVALHO, 2002, p. 61). Ou seja, na publicidade, a ambiguidade pode ser trabalhada tanto com palavras homônimas, como através de palavras que permitem várias leituras de um texto.

A publicidade se utiliza de recursos que facilitam a ligação lúdica entre a mensagem e o receptor, visando sempre ser compreendida e aceita pelo público a que se dirige. Nas palavras de Carvalho: 
A mensagem publicitária sempre utilizará as palavras com a carga cultural que possuem na comunidade em que será veiculada, tentando não contrariar o estabelecido, para que possa ser entendida e aceita. (2002, p. 108)

No entanto, apesar de trabalhar no limiar da perspectiva de ser entendida e aceita, sem contrariar a carga cultural que o público possui, a publicidade não diminui suas estratégias criativas, ao contrário, dentro da margem da aceitação, constrói sua linguagem de sedução. Para construir uma relação lúdica com o público, a linguagem publicitária utiliza-se de várias funções da linguagem, mas é caracterizada predominantemente pela função conativa, que visa persuadir o receptor, seduzi-lo.

A propaganda, por exemplo, marca-se fundamentalmente pela persuasão - isto é, pela intenção de seduzir o receptor. A organização, portanto, da mensagem da propaganda, seja qual for o veículo que a estruture - televisão, revista, outdoor, rádio -, imporá um perfil conativo a essa linguagem. (CHALHUB, 1999, p.07).

Chalhub (1999) explica que uma mensagem pode ter mais de uma função de linguagem, no entanto, com predominância de alguma delas. Para ela, a função conativa se relaciona com a mensagem publicitária porque é centrada em atingir o receptor e visa sensibilizar o público pela beleza da argumentação. Os anúncios, em geral, também apresentam a função poética, cujo fator marcante é a própria mensagem, só que de modo diferente "da função estética da arte, que não intenciona persuadir para fins de consumo." (CHALHUB, 1999, p. 25).

A persuasão é, portanto, uma marca forte na linguagem publicitária, que visa atingir um público-alvo, ou seja, a publicidade mercadológica precisa sensibilizar até convencer seu público a comprar. Assim:

[...] A maioria dos produtos pouco ou nada se diferencia uns dos outros, e a propaganda passa a ser ela própria o diferencial. Consequência: mensagens esteticamente impecáveis e recursos persuasivos casa vez mais eficientes. (HOFF; GABRIELLI, 2004, p. 02-03).

Para Nelly de Carvalho (2002), outras linguagens, a exemplo da jornalística, política e jurídica e até a amorosa também se utilizam da persuasão para manipular as mensagens, de acordo com os objetivos de quem emite a informação. Porém,

A diferença está no grau de consciência quanto aos recursos utilizados 
para o convencimento e, nesse sentido, a linguagem publicitária se caracteriza pela utilização racional de tais instrumentos para mudar (ou conservar) a opinião público-alvo. (CARVALHO, 2002, p. 09)

Já em relação ao termo utilizado, optamos por conceituar nosso objeto de estudo como sendo da publicidade em detrimento do termo propaganda, porque o primeiro é mais ligado à atividade de persuasão em nível comercial, enquanto a propaganda é, historicamente, um construto mais ligado à atividade político-ideológica, ou seja, a um nível referente à esfera política, institucional, religiosa e ideológica. Além disso, a utilização do termo publicidade tem predominado no meio acadêmico. Segundo o levantamento feito aos anais do Congresso Brasileiro de Ciências da Comunicação entre 2003 e 2008 por Formiga Sobrinho (2009), o uso do termo publicidade predominou a maioria das pesquisas neste período e identificou uma escolha crescente pelo uso de publicidade entre os pesquisadores. "O emprego do termo é crescente, no decorrer dos últimos 4 anos, sendo que, nos últimos 2 , a diferença entre o emprego dele e de propaganda ficou ainda maior: 32\%, em 2006, e 40,7\%, em 2007.” (FORMIGA SOBRINHO, 2007, p. 117). Por isso, neste trabalho, optamos por utilizar o termo publicidade.

Nelly de Carvalho (2002) e Everardo Rocha (2006) contribuem para pensar na ligação entre a publicidade e a sociedade de consumo. A publicidade, segundo Carvalho, seria o elo entre a população e o consumo, e cumpre esta finalidade atuando conjuntamente, por 3 vias: a psicológica, a antropológica e a sociológica. A psicológica se cumpre no sentido psicanalítico porque o anúncio é recebido de forma erótica; a antropológica, porque os signos publicitários reavivam arquétipos; já a sociológica proporciona ao receptor sensação de pertencimento à sociedade e também de singularidade.

A linguagem publicitária é feita de rupturas, advindas do processo criativo e também da adaptação necessária para que a objetividade da mensagem seja alcançada. Trata-se de "tornar familiar o produto que está vendendo, ou seja, aumentar sua banalidade, e ao mesmo tempo valorizá-lo com uma certa dose de "diferenciação", a fim de destacá-lo da vala comum" (CARVALHO, 2002, p. 12).

No entanto, nem tudo são mudanças. Algumas continuidades se revelam na linguagem publicitária, como a presença de personagens, sejam elas celebridades ou 
não, o erotismo, o recurso do humor e o uso de estereótipos como representações partilhadas culturalmente pela sociedade (SOUZA, 2011). Diante da última estratégia, seria insuficiente dizer que a publicidade é machista ao veicular representações da mulher baseadas em personagens estereotipadas como a dona de casa, a bela mulher ou a sedutora femme fatale, pois de acordo com os Estudos Culturais, a manutenção do poder também se dá através da cultura, da construção do poder simbólico, do que é socialmente aceito e partilhado.

Neste sentido, se as peças publicitárias de cerveja têm se mantido por anos utilizando-se da construção de personagens femininas sexualizadas ou erotizantes é porque os códigos culturais partilhados em nossa sociedade têm contribuído para esta manutenção. Se assim não fosse, a estratégia publicitária não seria mantida, já teria fracassado. Talvez este seja o ethos da publicidade de cerveja, que, a propósito, tem suas mensagens direcionadas ao público masculino. "Visivelmente as peças são direcionadas ao público masculino que, apesar de não estar presente graficamente, é o observador natural e para quem toda a linguagem publicitária é direcionada." (DIAS, 2011, p. 96).

Dessa maneira, partimos para observar as relações de gênero construídas pela publicidade como forma de perceber as significações sociais em torno do feminino e do masculino na cultura. Também nos interessa analisar como as mensagens publicitárias afetam o imaginário coletivo e observar como elas também são construídas a partir do imaginário, pois: "A mídia de massa produz e reproduz memórias coletivas, desejos, esperanças e medos e assim assume uma função similar àquelas dos mitos nos séculos passados" (LIESBET VAN ZOONEN, 1996, p. 37).

No sentido de atender ao público a que se destina, a publicidade de cerveja utiliza códigos culturais vigentes no diálogo com o público masculino e feminino. Sendo assim, a publicidade é um tema fundamental para entender a cultura contemporânea.

\subsubsection{Construção das Narrativas do Cotidiano}

Antes de darmos início propriamente ao tema da construção de personagens publicitários, vamos falar um pouco sobre narrativas, pois é através delas que os personagens passam a existir. 
Crescemos ouvindo histórias. Quando crianças, lemos e vemos mundos fantásticos em histórias infantis. Já pré-adolescentes, podemos encontrar um passatempo nos quadrinhos, depois no cinema, nos livros e na televisão. Vivemos cercados por narrativas, seja da História, da literatura ou das mensagens dos meios de comunicação com os quais temos contato constante.

Existem narrativas na literatura, nas imagens, nos quadrinhos, nas fotografias, no cinema, na história oral ou nos jogos. As narrativas dão sentido à vida humana há muito tempo, pois antecedem a escrita e atendem a uma necessidade imanente de sociabilidade humana (BARTHES, 1976).

Muitos autores se debruçaram em caracterizar as narrativas. Uns tentaram decifrar suas estruturas e formas, como os estruturalistas Roland Barthes (1976), Tzvetan Todorov (1976) e Umberto Eco (1976). Outros viram, através do cinema, que não existe divisão entre "imagem atual", aquela que vemos no presente e é mais ligada à objetividade; e "imagem virtual", aquela que vemos no passado contemporâneo, associada à lembrança pura e ligada à subjetividade. Como exemplo, Gilles Deleuze (1985), chegando ao conceito de imagem-cristal, que desdobra "o presente em duas direções heterogêneas, uma se lançando em direção ao futuro e a outra caindo no passado" (Deleuze, 1985, p. 102); e de "cristais do tempo", movimento de viajar no passado e no futuro, construindo um circuito - misturado e sem ponto de origem - de ligações entre o atual e virtual.

Alguns autores, como André Gaudreault e François Jost (2009), baseados em Aristóteles, dizem que toda narrativa é um discurso fechado e se opõe ao mundo real, já que forma um todo, com começo, meio e fim. Já para Rick Altman (2008), o acompanhamento é o mais importante na narrativa, que ele define como uma sequência de ações percebidas, mais do que ter começo, meio e fim.

De acordo com Roland Barthes (1967), existem nas narrativas, níveis, estágios que conduzem a compreensão da história. Ele propõe a análise da narrativa a partir de três níveis de descrição, o das funções, das ações e da narração, sendo esses níveis ligados entre si.

No nosso caso, estamos propondo ir além da estrutura e observar as significações, as relações entre personagens, o contexto sociocultural em que se constrói a narrativa e o movimento que vai da cultura à comunicação e da comunicação à cultura, pois acreditamos que é o receptor que dá o sentido final à mensagem 
publicitária.

No entanto, as colaborações dos estruturalistas são fundamentais para este trabalho, pois ajudam a pensar os elementos da narrativa e nos dão base para análise, como é o caso das contribuições de Tzvetan Todorov (1976), que tratou dos personagens e de suas relações. Para ele, a narrativa pode ser analisada como história e como discurso. No plano da história, os personagens e suas relações - em relação com outros personagens - representam, na narrativa, "um papel de primeira ordem" (TODOROV, 1976, p. 220) e tem relações diversas.

Os receptores das narrativas são envolvidos num enredo que se configura em mais do que encadeamentos e os levam a recriar situações e comportamentos sugeridos pelas histórias, numa relação de referência e resignificação. Desse modo, as narrativas podem elucidar elementos importantes de significação social, pois:

Os significados provêm não só dos processos de recriação mimética, mas também da relação inversa, da identificação virtual que ocorre em toda narrativa, da transposição catártica que as pessoas fazem das estórias narradas para as suas próprias experiências. Quando escutamos (oralidade, canção, rádio), quando assistimos (teatro, filme, telenovela, telejornal) ou quando lemos uma estória (jornal, revistas, livro) estamos na estória, e recriamos a sua significação a partir da relação que fazemos com os nossos próprios valores e nossa memória cultural. (MOTTA, no prelo).

Contar, ouvir ou ler histórias são atividades que provocam efeitos na leitura de mundo dos sujeitos sociais, pois as expressões narrativas produzem sentidos na medida em que expressam e representam experiências, gerando nos receptores um processo de identificação. A partir dos códigos culturais que possuem, estes recriam significações culturais na relação com a sociedade. Portanto, as narrativas excedem os limites do texto e expandem-se:

[...] para situar-se ao nível das relações culturais, dos atos de falas em contexto, aos usos pragmáticos da linguagem em situações e sociedades culturalmente localizadas. (MOTTA, no prelo)

Assim como a literatura, o teatro, o cinema e a televisão, a publicidade constrói narrativas através de diversas linguagens que contemplam os códigos verbal, visual e audiovisual. Isto porque os sujeitos vivem narrativamente no mundo e a publicidade constrói narrativas que causam efeitos de sentido nos receptores. Um dos recursos utilizados pela publicidade é o personagem, construído para provocar identificação entre o público e a mensagem publicitária, e envolvendo o consumidor no enredo publicitário. 
Mensagens desse tipo procuram trabalhar com a dimensão emocional do consumidor, utilizando-se de recursos semelhantes aos encontrados na literatura e no cinema, como é o caso da construção de uma personagem. (FORMIGA SOBRINHO, 2004, p. 9)

As narrativas publicitárias são resultado das relações de produção relativas a seu trabalho e dizemos isso para tratar de suas peculiaridades, como por exemplo, o tempo reduzido que os profissionais da área dispõem para contar uma história, principalmente, se tratamos de vídeos veiculados em rede de televisão aberta, que comumente têm entre 30 e 60 segundos. Isso também contribui para tornar recorrente o uso de clichês e estereótipos já aceitos e que são entendidos com facilidade pelos receptores.

Jacques Aumont (2001, p. 250) preconiza que:

\begin{abstract}
A imagem publicitária, concebida por definição para ser facilmente interpretada (sem o que ela é ineficaz) é também uma das sobrecarregadas de todo tipo de códigos culturais. [...] o trabalho dos criadores consiste em fabricar imagens que possam ser lidas com aplicação de diferentes estratégias, segundo o número e a natureza dos códigos mobilizados, e em tornar essas estratégias compatíveis; assim, o espectador mais culto, ou mais "atualizado", captará alusões, citações e metáforas que escaparão a uma leitura mais rudimentar, mas em todos os casos um significado comum deve estar presente, sob pena de insucesso.
\end{abstract}

Apesar de ter o objetivo de vender produtos e fomentar o consumo, não é apenas esta a finalidade da publicidade. Ela é uma narrativa da contemporaneidade, repleta de símbolos, mitos e estereótipos. Se ela não faz com que o receptor imediatamente consuma um produto específico, ela pode influir em identidade e comunicar estilos de vida.

Nos vídeos publicitários são narradas histórias calcadas na nossa cultura, de forma curta, abordando nosso cotidiano, mas repletas de simbolismos, de modo que ocorra sim fruição e a produção de sentido. Os personagens, neste sentido, são importantes porque criam adesão imediata, subjetivando as mensagens. A publicidade proporciona ao receptor um encontro entre o presente e o futuro, entre o mundo real e o mundo possível, entre a realidade e o sonho. Por isso é que muitas vezes as peças publicitárias são acusadas de fazer uso estereotipado de personagens e situações, pois em 30 ou 60 segundos é preciso contar, de forma que não restem dúvidas, o que se precisa 
dizer. Portanto, sempre vai haver um significado comum e que, na maioria das vezes, está localizado nas construções de personagens de forma estereotipada ou em situações clichês presentes no próprio texto das peças publicitárias, porque facilita o entendimento e a geração de sentidos.

[...] os estereótipos são úteis à publicidade por, ao menos, três motivos. Em primeiro lugar, porque permitem comunicar rapidamente a mensagem persuasiva, o que resulta em lucro considerando as elevadas tarifas dos espaços e tempos publicitários. Em segundo lugar, o emprego de estereótipos não mina os pilares da ideologia dominante, garantindo a continuidade de um sistema que se mostra muito vantajoso para o setor publicitário, que cresce ano após ano acima da média do resto das atividades econômicas. E, em terceiro lugar, os estereótipos reduzem o esforço cognitivo do receptor, que assume passivamente o re-conhecido no discurso. [...] O verdadeiramente importante, do ponto de vista da eficácia comunicativa do anúncio, não é que a imagem estereotipada que projeta o anúncio correlacione com a realidade sociológica, mas com a simplificada imagem que a dita categoria social compartilha em comum com os cidadãos. (LORA, 2008 , p. 189 , tradução nossa). ${ }^{22}$

Desse modo, apesar do pouco tempo de que dispõe para contar suas histórias, a publicidade precisa ser coerente, ficando a cargo do receptor o papel de preencher as lacunas das narrativas.

Neste sentido é preciso afirmar que houve uma evolução na estrutura das narrativas publicitárias, pois se antes os comerciais eram a exibição dos produtos para câmeras paradas, este conceito mudou completamente, tendo sido, as mudanças, fortemente influenciada pela linguagem cinematográfica, daí termos utilizado, anteriormente, alguns teóricos que tratam do assunto. Além disso, a inserção das peças publicitárias na programação da televisão faz parte da própria estrutura televisiva, misturando ficção e realidade a toda hora.

Flausino (2012) lembra que a publicidade trabalha somente com o que está sancionado socialmente, não tem objetivo de questionar valores, e sim ancorar narrativas no real, trabalhando o que o público-alvo já incorporou à sua experiência

\footnotetext{
${ }^{22}[\ldots]$ los estereótipos son útiles a la publicidade por, al menos, tres motivos. En primer lugar, porque permiten comunicar rapidamente el mesaje persuasivo, lo que resulta muy rentable considerando las elevadas tarifas de los espacios y tempos publicitários. En segundo lugar, el empleo de estereótipos no socava los pilares de la ideologia dominante, garantizando la continuidade de un sistema que se muestra muy ventajoso para el sector publicitário, que crece año tras año por encima de la media del resto de actividades económicas. Y, em tercer lugar, los estereótipos reducen el esfuerzo cognitivo del receptor, quien assume passivamente lo re-conocido em el discurso. [...] Lo verdadeiramente importante, desde el punto de vista de la eficácia comunicativa del anuncio, no es que la imagen estereotipada que proyecta el anuncio correlacione com la realidade sociológica, sino más bien com la simplificada imagen que de dicha categoría social comparte el común de los cuidadanos. (LORA, 2008, p. 189)
} 
social. No entanto, isto não significa dizer que não há margem para a criatividade, mas sim que a publicidade utiliza estratégias criativas e inovadoras dentro dos códigos culturais mobilizados e compatíveis com as leituras e vivências partilhadas pela sociedade.

É importante lembrar que o personagem principal na publicidade é o produto, e que os personagens que compõem as narrativas publicitárias existem para gerar identificação pelo riso, pela lágrima ou pela surpresa. Os personagens construídos geram identificação justamente porque mostram a imagem de como é a pessoa que consome aquele produto, podendo causar fruição. (Flausino, 2012).

\subsection{Mulher na Publicidade}

A mulher é representada na Publicidade há bastante tempo. Podemos encontrar, predominantemente, a imagem de uma mulher mais ligada à família, que consome produtos de beleza e é responsável pela escolha de produtos diversos relacionados ao consumo da família e aos cuidados com a mesma.

No entanto, com as modificações na condição da mulher na sociedade, as consumidoras não se sentem mais seduzidas apenas por este tipo de mensagem publicitária, ou seja, por um tipo de discurso que liga suas necessidades à tarefa de agradar aos homens. A aceitação da publicidade na sociedade tem relação com os costumes da população. Everardo Rocha (2006) lembra a relação entre mulher, pecado e demônio presente na sociedade judaico-cristã, que vem desde a relação da queda do homem por causa do pecado original, no Gênesis. Neste movimento, a mulher na publicidade aparece oscilando entre a imagem de mãe, dona-de-casa e símbolo erótico.

A presença das mulheres na publicidade é um recurso utilizado desde o surgimento dos meios de comunicação de massa. Edgar Morin (1969) dedicou um capítulo para discutir a relação entre a publicidade e os valores femininos. O Eros quotidiano é como o autor descreve o uso do erotismo pela publicidade.

É que se operou uma espantosa conjunção entre o erotismo feminino e o próprio movimento do capitalismo moderno, que procura estimular o consumo. O dinheiro, sempre insaciável, se dirige ao Eros, sempre subnutrido, para estimular o desejo, o prazer e o gozo, chamados e entregues pelos produtos lançados no mercado. Em sua expansão 
"vertical", o capitalismo, depois de haver anexado o reino dos sonhos, se esforça por domesticar o Eros. Ele mergulha na profundeza do onirismo e da libido. Reciprocamente, o Eros entra triunfalmente no circuito econômico, e, dotado do poder industrial, desaba sobre a civilização ocidental. (MORIN, 1969, p. 120).

Esse erotismo presente na publicidade desde seu nascimento tem forte relação com a presença e o uso das mulheres. Segundo Morin, o capitalismo incentivou todos os tipos de consumo, inclusive o amoroso. O erotismo seria "o denominador comum entre o universo do amor, o da promoção dos valores femininos e o do consumo." (MORIN, 1969, p. 124).

Ainda segundo Morin, a cultura de massa se dirige para promoção dos valores femininos. Não existem setores especificamente masculinos na cultura de massa. Já as mulheres ocupam um espaço gigantesco.

\begin{abstract}
A mulher modelo desenvolvida pela cultura de massa tem aparência de boneca do amor. As publicidades, os conselhos estão orientados de modo bastante preciso para os caracteres sexuais secundários (cabelos, peitos, boca, olhos), para os atributos erógenos (roupas de baixo, vestidos, enfeites), para um ideal de beleza delgado, esbelto - quadris, ancas, pernas. A boca perpetuamente sangrenta, o rosto pintado seguindo um ritual são um convite permanente a esse delírio sagrado de amor que embota, evidentemente, a multiplicidade quotidiana do estímulo. (MORIN, 1969, p.141)
\end{abstract}

No entanto, Morin (1969) afirma que, do mesmo modo que há uma feminilização da cultura marcada pelo arquétipo de mulher sedutora e doméstica, há uma feminização do homem. É preciso reiterar que estas reflexões datam de meados do século XX, o que pode nos levar a refletir sobre algumas permanências e rupturas em suas análises. Hoje podemos afirmar que há uma indústria cultural também dirigida ao público masculino, mesmo que essa mesma indústria utilize da mulher e da sedução de Eros para vender variados produtos e objetos de sua cultura. Produtos ligados a futebol, carros, mundo dos negócios e economia parecem dialogar com o público-alvo masculino. No entanto, segundo Everardo Rocha (2006), existem diferenças sobre na forma como a publicidade trata a individualidade masculina e a feminina, ao se dirigir a estes públicos específicos.

As diferenças começam a aparecer, na representação da identidade feminina, quando investigamos os valores que são, especificamente, distribuídos para construir essa individualidade. Nesse plano, a mulher 
indivíduo vira corpo e o que entra em jogo é sua posse, uso, beleza, tratamento e realce, pois o corpo é a propriedade, bem e valor fundamental - no limite exclusivo - dessa individualidade. (ROCHA, 2006, p.55).

Além de focar a individualidade feminina baseada no corpo e na beleza, às vezes este corpo é fragmentado na publicidade. Para Inês Senna Shaw (2002), o corpo é, frequentemente, utilizado para vender todo tipo de produto, mas, segundo ela, há um uso desproporcional da representação feminina nas peças publicitárias.

Talvez as mais óbvias sejam as sobre a sexualidade, como a de que o desejo da mulher por sexo masculino é sua maior preocupação, ou que a mulher atrai ou merece o estupro, ou que a função fundamental do homem é dominar a mulher sexualmente. Essas representações e estórias culturais são articuladas por sua vez dentro das dimensões morais, sexuais, e sociais das ideologias de gênero que organizam a visão dos agentes criadores (SHAW, 2002, p.194).

Podemos observar que, ao ser direcionada para as mulheres, a publicidade apresenta o corpo feminino abordando a importância de conquistar ou manter o corpo perfeito, ideal, a busca pela beleza. É o que afirma Silveira (2013) ao analisar as peças publicitárias das Lojas Renner, veiculadas em 2011, dizendo que elas funcionam, para as mulheres, como incentivadoras pela busca de um padrão corporal perfeito, construindo uma sensualidade pautada na magreza. Brisolla (2006) também constata que na campanha de anúncios impressos da Dove de 2004 a 2005, o padrão de referência é a mulher branca, cabelos lisos, corpo bem cuidado, mesmo com uns quilos a mais, reforçando a exposição do corpo da mulher a projeções sociais. Já quando direcionadas aos homens, o corpo feminino é utilizado de forma fragmentada, focando em alguma parte de seu corpo ou apresentando a mulher como consequência, recompensa ou decoração em virtude da escolha daquele homem pelo produto publicizado em questão. Assim como Pires (2007) que constata a presença da bundalização nas propagandas impressas das revistas Cruzeiro, Manchete e Veja entre o período 1957 e 1997. Já, de acordo com Rocha (2006) na publicidade em que os homens aparecem, apesar de, também, em algumas peças ter a presença do corpo e do nú, eles são retratados de maneira mais integral, sendo a sua individualidade amparada pela ação de seus próprios desejos, intrínsecos aos cenários presentes na publicidade. No entanto, de maneira geral, este ser masculino está construído sob a ótica de uma masculinidade hegemônica. 


\subsection{Estudos de criatividade}

A publicidade é uma atividade profissional permeada pelos fatores da criatividade. Desde a pessoa criativa, configurada no publicitário, até o resultado da expressão da criatividade, as peças ou campanhas publicitárias, vemos a criatividade permeando todo o processo de produção publicitária. Evidentemente, existem as negociações empreendidas entre a cultura, o indivíduo e os desafios de manter a linguagem atual, pois a publicidade é uma atividade voltada especialmente para atender o público-alvo e atingir seus objetivos comerciais com a venda dos produtos.

Para dar prosseguimento a esta e outras reflexões, vamos analisar o produto publicitário com base nos estudos da criatividade.

Para isto, utilizaremos a definição de criatividade apresentada por Lubart como "uma expressão da atividade humana que resulta numa produção nova e adaptada ao contexto a que ela se manifesta" (LUBART, 2007, p. 16). Por outro lado, não basta ser algo novo para ser criativo, é preciso que se diferencie das soluções encontradas anteriormente e que atenda as necessidades das pessoas. Ou seja, não é somente por ser nova que uma produção se torna criativa, mas também por ser relevante, ter sido pensada de forma singular para atender as necessidades esperadas, portanto, é preciso ser socialmente importante (LUBART, 2007).

Bruno-Faria (2003) contribui para pensarmos neste sentido, no contexto das organizações, ao considerar que:

Criatividade é a geração de idéias, processos, produtos e/ou serviços novos (para aquele indivíduo/grupo ou naquele contexto) que possam produzir alguma contribuição valiosa para a organização e/ou para o bem estar das pessoas que trabalham naquele contexto e que possuam elementos essenciais à sua implementação. (BRUNO- FARIA, 2003, p. 117)

No entanto, apesar de a abordagem ser organizacional, podemos pensar em criatividade nesta direção de produzir uma contribuição valiosa para a organização ou para o bem estar das pessoas em determinado contexto social. Por isso, as contribuições de Csikszentmihalyi (1996) são fundamentais, ele aborda a criatividade permeada por fatores ambientais do contexto sócio-histórico e cultural no qual se encontra o indivíduo. $\mathrm{O}$ autor considera que "é a comunidade, e não o indivíduo que 
manifesta a criatividade" (CSIKSZENTMIHALYI, 2006, p.333). Com sua visão sistêmica, ele aborda a criatividade como um processo mais coletivo e resultante da interação entre 3 sistemas: indivíduo; campo, integrado por juízes, que são os especialistas em um domínio de expressão, ou seja, em uma área de atuação específica, e assim se tornam aptos a avaliar o nível de criatividade das produções; e área ou cultura.

Como exemplo, podemos citar no domínio de expressão da publicidade, que pode ter como juízes, os publicitários e o público e integra a cultura de um país.

[...] o que chamamos de criatividade é um fenômeno construído através de uma interação entre o produtor e a audiência. Criatividade não é o produto de indivíduos isolados, mas de sistemas sociais que fazem julgamentos sobre os produtos dos indivíduos. (CSIKSZENTMIHALYI, 2006, p. 313).

Assim os estudos da criatividade, passaram a considerar a cultura como elemento fundamental desta atividade humana, pois até então a criatividade era vista como mística, como algo que nascia com a pessoa, um dom divino. De acordo com textos gregos e Platão, por exemplo, a criação de um poeta dependia da musa inspiradora (LUBART, 2007). No entanto, Aristóteles discordou de Platão dizendo que a inspiração nasce no interior do indivíduo, "dentro de associações mentais, e não em intervenções divinas." (LUBART, 2007, p. 12).

A ideia de associar misticismo e criatividade retorna no período do Renascimento, surgindo, no século XIX, intensos debates sobre criatividade. Mas, foi somente a partir de Duff, em 1967, que se deu início a diferenciação entre gênio criativo e talento, e a criatividade se dissociou da visão sobrenatural que até então possuía.

Após a intensificação dos estudos sobre criatividade, essa visão de mundo foi desfeita e hoje se sabe que vários fatores influenciam na expressão da criatividade. Freud, por exemplo, disse que a criatividade era "uma expressão dos desejos inconscientes por meio de meios culturalmente aceitáveis". (LUBART, 2007, p. 13).

Para entender os estudos da criatividade é preciso levar em consideração a pessoa, o processo e o produto envolvidos nela. No entanto, nosso enfoque será no produto criativo, que no caso, são os vídeos publicitários da Skol dos últimos 10 anos, veiculados na televisão aberta. 
A pessoa criativa é influenciada por fatores cognitivos, de personalidade e emocionais. Os fatores cognitivos seriam os ligados à inteligência e ao conhecimento, os de personalidade, ao comportamento e à motivação da pessoa para resolver o problema/ tarefa. Já os emocionais seriam "noções de estado emocionais, de humor e de características emocionais individuais”. (LUBART, 2007, p. 56)

Em relação ao processo criativo, alguns estudiosos tentaram identificar o caminho da criatividade, ou seja, as etapas do processo criativo. Segundo Lubart (2007, p. 93), a noção de processo criativo remete à sucessão de pensamentos e ações que desembocam nas criações originais e adaptadas. Wallas foi o primeiro a criar, em 1926, um modelo de processo criativo dividido em 4 etapas: preparação (descoberta do problema), incubação (descanso e jogo associativo inconsciente), iluminação (emergência da ideia) e verificação (exame crítico da ideia), tendo o próprio autor apontado, posteriormente, a não linearidade das fases e outros autores desenvolvido modelos circulares e dinâmico do processo criativo.

Já o produto é o resultado da criatividade, no caso da publicidade, os anúncios e outras estratégias que não necessariamente envolve o uso dos meios de comunicação de massa. Também cabe ao produto da publicidade atingir corretamente e dialogar com o público-alvo a que se destina, portanto, o contexto e a aceitação são fundamentais durante todo o processo criativo. Esse ambiente que cerca a publicidade influencia a pessoa, o processo e o produto criativos e também por eles é influenciado. Como já dissemos anteriormente, nesta pesquisa nosso foco será na análise do produto criativo publicitário, embora não seja possível ignorar os demais fatores.

Até os anos 1970, os estudos de criatividade pairaram em torno de identificar os componentes para a atividade criativa e se esforçaram para traçar um perfil da pessoa criativa e desenvolver técnicas para essa expressão. No entanto, após esse período os estudiosos centraram forças em entender os fatores socioculturais e históricos no desenvolvimento da criatividade que até então vinham sendo negligenciados. Desde então, ficou mais evidente o fato de uma produção ser reconhecida como criativa somente se passar pelo crivo de pelo menos parte da sociedade que partilha uma cultura. Assim como os estudos culturais trouxeram uma visão mais global para a análise dos meios de comunicação, conteúdos e formas de produtos comunicacionais, entendendo-os para além do poder econômico e de entretenimento e considerando as trocas simbólicas neles e por eles promovidas, a abordagem 
culturalista deu um salto na análise desse objeto de pesquisa complexo que é a criatividade.

No caso da publicidade, é fundamental levar em consideração os fatores ambientais no uso da criatividade, já que tanto o processo criativo publicitário, quanto o próprio produto, é voltado para atingir o público e para isso é preciso haver aceitação. Não basta ser algo novo é preciso estar adaptado ao contexto social e dialogar com este contexto.

O discurso publicitário visa a ganhar a adesão, tanto intelectual quanto emotiva, do público-alvo e levá-lo à ação - comprar o produto ou serviço. Para torná-lo persuasivo, a dupla de criação precisa buscar material para criar, ou seja, precisa encontrar as ideias originais, expressivas e adequadas à visão de mundo do público-alvo. (HOFF, GABRIELLI, 2004, p. 57).

Esta negociação com os valores culturais presentes na sociedade permeia a publicidade desde o processo criativo até o processo final da criação, portanto as peças publicitárias nunca resultam apenas da ideia brilhante da mente da dupla de criação de uma agência de publicidade, está sim relacionada ao encadeamento de ideias, ao envolvimento com o trabalho, ao momento ser favorável, entre outros fatores. Ou seja, ela se realiza a partir da interação entre originalidade e adequação ao contexto social. Entendendo originalidade na publicidade quando "o texto destaca-se dos demais, por ter sido construído de maneira pouco usual, estabelecendo associações inéditas" (HOFF, GABRIELLI, 2004, p. 101) e adaptação quando "o repertório da mensagem está adequado ao do receptor". (HOFF, GABRIELLI, 2004, p. 101).

Outro critério importante, no caso da criatividade, é o da inovação, que para nossa pesquisa será fundamental. É tarefa complexa conceituar inovação. Contudo, Bruno-Faria (2003) nos ajuda a refletir sobre isso, ao tratar da estreita relação entre criatividade e inovação e chamar a atenção para diferenças e semelhanças entre os termos.

Na conceituação feita por Kin, em 1995, e citada por Bruno-Faria (2003), temos uma perspectiva de inovação condizente com nosso trabalho:

Inovação é a sequência de atividades pelas quais um novo elemento é introduzido em uma unidade social, com a intenção de beneficiar a unidade, alguma parte dela ou a sociedade mais ampla. O elemento não necessita ser inteiramente novo ou não-familiar para os membros da unidade, mas ele envolve alguma mudança perceptível ou desafio para o status quo. (BRUNO-FARIA, 2003, p. 121). 
Este conceito atende ao que esperamos observar ou ser observado pelo público como inovação ou como sua antítese, no que se refere à forma de abordar as relações de gênero na publicidade de cerveja. No entanto, é preciso dizer que inovação não é aquela que se faz uma única vez, mas sim a que se verifica de forma continuada. A inovação implica uma mudança dinâmica e não a criação de novos produtos em massa, como se pensava nos anos 1950 e 1960. Nos anos 1980 essa ênfase foi alterada para inovação como melhoria dos produtos, introduzindo a ideia de melhoria contínua, e não mais somente o novo pelo novo.

Neste sentido, cabe destacarmos o fato de não bastar ser novo para ser um produto criativo; e o fato de nosso interesse estar no reconhecimento ou não da implementação de novas ideias pela marca Skol. Em outras palavras, pretendemos refletir sobre a inovação como "alguma mudança perceptível ou desafio para o status quo". (BRUNO-FARIA, 2003, p. 121), atentando para as mudanças e continuidades nas peças publicitárias de cerveja Skol.

Em relação ao novo, a concepção da criatividade para o mundo ocidental está predominantemente alinhada com a novidade, focada em produtos de inovar, o que se diferencia da concepção oriental da criatividade, que "parece envolver a reinterpretação de ideias tradicionais - encontrar um novo ponto de vista, enquanto que na abordagem ocidental, a criatividade envolve uma ruptura com a tradição (KRISTCLLER, 1983).” (LUBART, 2006, p. 33). Ainda de acordo com Lubart (2006), a visão da criatividade oriental parece com um movimento circular, de desenvolvimento e desdobramento, de continuidade, enquanto a ocidental parece caminhar em linha reta, em direção ao novo. Portanto, dependendo do contexto em que a atividade criativa se realiza, ela pode ser interpretada de maneira diferenciada, pois para uma cultura o novo pode ser fundamental e, para outra, a continuidade faz parte do criativo.

Assim, inovação e criatividade são influenciadas por fatores contextuais como política, economia, história, cultura e organização social; e nos dão elementos para pensarmos esta relação entre rupturas e continuidades, tradição e modernidade, pois se, por um lado, a criatividade no mundo ocidental orienta-se pela novidade, por outro:

É útil pensar sobre a criatividade como envolvendo uma mudança de memes - as unidades de imitação de Dawkins (1976) sugeridas 
como os blocos de construção da cultura. Memes são similares aos genes em que eles carregam instruções para a ação. [...] De um modo geral, aprendemos memes e reproduzimos sem alterações, quando uma música nova ou uma nova receita é inventada, então temos a criatividade. (LUBART, 2006, p. 316)

Então, podemos dizer que pensar em criatividade nos dá pistas para pensar nos produtos culturais diante: da tensão entre a tradição e a novidade, entre o original e o arcaico; das continuidades e as rupturas do processo criativo, para além do discurso produtivo do novo da economia criativa; e de um produto ou uma ideia que se sobressai como nova e, ao mesmo tempo, é construída a partir dos valores e códigos culturais já existentes e compartilhados pela sociedade.

Os estudos de criatividade, portanto, ajudam-nos a refletir sobre a criação publicitária, seu diálogo com símbolos arraigados na cultura e com o contexto social presente, ou seja, permitem-nos enxergar o produto publicitário tanto como a produção baseada na solução de tarefas de forma original, quanto algo vinculado a atualidade, tendo como referência os valores compartilhados pela sociedade.

Já a inovação é a perspectiva que se aplica tanto a produtos, como a processos, ou seja, a melhoria contínua de uma ideia, produto ou processo, de modo que ele se mantenha com força e aceitação, e seja perceptível para a sociedade, beneficiando-a diante de um problema colocado pela sociedade para ser resolvido. No caso da publicidade, a inovação está ligada à mudança no processo, à forma como se trabalha e produz o produto e também, inevitavelmente, ao comportamento dos agentes criadores que são balizados pela cultura.

No entanto, a inovação não está somente nos bens físicos e no seu processo de produção, mas também nos bens intangíveis. Evidentemente que a tônica das empresas, tem em vista, como fator principal, o seu crescimento econômico e as inovações serão implementadas visando atingir este objetivo.

Assim, os estudos de criatividade serão importantes para observamos como o produto publicitário não está isolado dos fatores que envolvem uma atividade criativa, é sim resultado de um processo que envolve indivíduo, cultura e julgamento social. Além disso, ao abordar a questão da inovação em se tratando de uma empresa, estamos falando em adoção de estratégias que visem aumentar lucros e fortalecer a marca. É com este olhar que partimos rumo a atingir nossos objetivos de pesquisa. 


\section{OBJETIVOS}

\section{Objetivo geral}

Analisar como ou se as campanhas de cerveja Skol, produtos da criatividade publicitária dos últimos 17 anos, inovaram na abordagem das relações de gênero.

\subsection{Objetivos específicos}

- Identificar as inovações, atualizações ou mudanças dos símbolos, gestos e textos presentes na publicidade de cerveja Skol, no que concerne à construção das relações de gênero.

- Analisar se homens e mulheres se identificam com os personagens construídos na publicidade de cerveja Skol. 


\section{PROCEDIMENTOS TEÓRICO-METODOLÓGICOS}

A partir do exposto anteriormente, entendemos nosso objeto de pesquisa como produto da criatividade e inscrito na corrente dos Estudos Culturais, pois compreendemos a publicidade como um objeto permeado por códigos culturais que são utilizados durante a criação publicitária e que, ao serem difundidos nos meios de comunicação fomentam significações ou ressignificações na sociedade.

A tradição dos estudos culturais britânicos e latino-americanos foi e continua sendo importante para observar o simbólico, o cultural, o que é transmitido e sustentado pela cultura, por meio da formulação da própria cultura de massa que é produzida, difundida e modificada pelos meios de comunicação. Evidentemente que essa dita "massa", para os culturalistas, não é homogênea, e sim plural. Portanto, dependendo do contexto, das referências, enfim do repertório cultural, os receptores significam e se identificam de forma diferenciada com os produtos dos media. Já os estudos de criatividade, a partir da abordagem culturalista, vão contribuir no diálogo com os Estudos Culturais e nos dar os critérios de observação necessários para analisar as mudanças, inovações e continuidades presentes nas peças publicitárias de cerveja.

Os Estudos Culturais latino-americanos contribuem para pensarmos os estudos de recepção que têm como objetivo central observar a cultura no processo de comunicação, assim como suas significações e ressignificações junto aos receptores, entendendo as mensagens mediáticas como produto culturais capazes de elucidar o contexto das relações sociais.

Neste sentido, os estudos de recepção, os estudos de criatividade e a tradição dos estudos culturais latino-americanos e britânicos se tornam um aporte teóricometodológico interessante para olhar nosso objeto de estudo. Dizemos teóricometodológico porque realizamos um estudo de recepção, baseado em um grupo focal, com o mesmo perfil do público a que se destina a publicidade de cerveja da Skol, ou seja, com homens e mulheres entre 18 a 45 anos, de variadas classes sociais. Assim, adotamos, de acordo com Kellner (2001), uma abordagem multiperspectívica para interpretar nosso objeto de pesquisa.

Perspectiva, nessa análise, é uma óptica, um modo de ver, e os métodos críticos podem ser interpretados como abordagens que nos possibilitam ver traços característicos dos produtos culturais. Cada método crítico focaliza traços específicos de um objeto a partir de uma perspectiva distinta: a perspectiva evidencia ou elucida alguns 
elementos de um texto enquanto ignora outros. Quanto mais perspectivas usarmos num texto para fazer a análise e a crítica ideológica - sexual, semiológica, estrutural, formal, feminista, psicanalítica, etc. - melhor poderemos entender todo o espectro de dimensões e ramificações ideológicas de um texto. Segue-se, portanto, que uma abordagem multiperspectívica fornecerá um arsenal crítico, toda uma gama de perspectivas para dissecar, interpretar e criticar produtos culturais. (KELLNER, 2001, p. 130).

Por isso, dividimos os procedimentos para nossa pesquisa em duas etapas, respectivamente: a- Análise da linguagem, a partir dos vídeos publicitários e; bObservação do cenário, através da realização de grupos focais, mediada pela exibição dos vídeos publicitários de cerveja.

\section{7- A análise da linguagem}

Nesta seção, iremos analisar os vídeos publicitários de cerveja da marca Skol, veiculados na televisão aberta brasileira nos últimos 17 anos, com base na análise de conteúdo qualitativa. Mas antes é preciso que se diga como chegamos a este recorte temporal. Esses vídeos foram selecionados a partir de um recorte que a priori seria de 10 anos. No entanto, ao pesquisar sobre as campanhas da Skol, nos anuários do Clube de Criação de São Paulo, na página da própria marca e da Agência F/Nazca e na página www.youtube.com, fomos reconhecendo um fluxo interessante de comunicação publicitária que contemplava momentos de continuidades e de mudanças na forma de abordar as relações de gênero. Quando delimitamos o período durante o qual os vídeos característicos do referido fluxo, resolvemos ampliar o período de abrangência.

Para definirmos o corpus da nossa pesquisa, analisamos 37 vídeos publicitários, veiculados no período de 1996 a 2013, e chegamos a algumas categorias que guiaram nossa abordagem do trabalho de campo.

Ancoramos nossa análise de conteúdo em Bauer (2010) considerando, segundo ele, três etapas: pré-análise, exploração do material e tratamento dos resultados e interpretação. A primeira fase foi o a da organização, hipóteses e indicadores de interpretação, a segunda, da codificação das unidades de registro e a última, da categorização, que consistiu na classificação de elementos por semelhança e diferenciação e reagrupamento por características comuns. 
Em relação à análise de conteúdo (AC) que estamos propondo, Bauer (2010, p.192) diz que pode ajudar a refletir sobre a mediação simbólica, pois através da:

[...] reconstrução de representações, os analistas de conteúdo inferem a expressão dos contextos, e o apelo através destes contextos. Se enfocarmos a fonte, o texto é um meio de expressão. Fonte e público são o contexto e o foco de inferência. Um corpus de texto é a representação e a expressão de uma comunidade que escreve.[...] A $\mathrm{AC}$ nos permite reconstruir indicadores e cosmovisões, valores, atitudes, opiniões, preconceitos e estereótipos e compará-los entre comunidades. (BAUER, 2010, p. 192).

As categorias a que chegamos previamente, a partir da análise da linguagem dos vídeos da Skol, foram: Mulher como argumento de sedução da cerveja, Masculinidade hegemônica, Ausência das relações de gênero e Associação icônica entre mulher e cerveja. Elas serão tensionadas, posteriormente, com as entrevistas em campo, pois queremos investigar se o que percebemos na linguagem presente nos vídeos também é percebido pelos receptores ou se as mensagens são entendidas de maneira diferente. Assim, a análise prévia servirá de matriz metodológica para seguirmos e aprofundarmos as problemáticas da pesquisa, além de servir de parâmetro comparativo entre as nossas análises e as do público, o que poderá apontar coincidências e contradições para posteriormente chegarmos a conclusões.

Para refletir sobre as relações de gênero, utilizaremos Saffioti; recorreremos a Connel (1995), que contribui para nosso estudo a partir do conceito de masculinidades, inclusive a hegemônica; e Lauretis (1994), que contribui fundamentalmente para pensarmos sobre as relações de gênero e as tecnologias de gênero. Passaremos também pelas perspectivas de Butler (2010), Scott (1990), Louro (1997) e, Bourdieu (2002), no entanto, acreditamos que a perspectiva de Saffioti e as abordagens de Connel e Lauretis atende as nossas necessidades ao pensar em gênero relacionando-o com patriarcado.

Em seguida, partiremos para refletir sobre a linguagem atual da publicidade e suas estratégias criativas. Os estudos da criatividade vão contribuir para pensar os caminhos de atualização dos símbolos na contemporaneidade, a partir da observando dos fatores inovação, originalidade e adaptação das peças ou campanhas publicitárias em relação aos códigos culturais vigentes na sociedade. Assim como, o diálogo entre os símbolos arraigados na cultura e o contexto social presente, o que, consequentemente, pode nos revelar as relações de gênero constituídas socialmente. 


\subsection{Roteiros dos vídeos publicitários}

Nesta seção apresentaremos a análise preliminar dos vídeos publicitários da Skol do período de 1996 a 2013. Foram selecionados 37 vídeos, cuja duração total atinge 30 minutos.

\section{Skol Eu quero mais, Eu quero Skol, 1996}

Imagem: Homem tá no trânsito de uma grande cidade e vê outdoor de mulher com maiô amarelo, dentro de uma piscina, segurando uma garrafa de Skol. O personagem masculino sorri e imagina-se mergulhando na piscina, e ao mergulhar, a câmera faz o movimento de subida, mostrando o corpo da mulher, de baixo para cima. O homem fica na piscina, ao lado da mulher, com um copo de cerveja Skol na mão. A câmera abre e mostra um casal abraçado, foco em uma lata de Skol sendo aberta, e mostra as pessoas ao redor da piscina, homens de short amarelo e mulheres de maiôs e biquínis, todos dançando.

Trilha: Música que diz: eu quero mais, eu quero Skol. O dia tá tão bonito, o sol dá a direção, sai de baixo, tô subindo, eu quero mais que uma paixão. Eu quero mais, eu quero Skol (4x). O sabor da gente, eu quero mais que quero Skol, Skooool.

Imagem: A câmera vem nessa direção, de baixo pra cima, com a mulher dentro da piscina, de biquíni amarelo. Os braços da mulher estão abertos, com a mão direita para baixo e a esquerda segurando a garrafa de Skol.

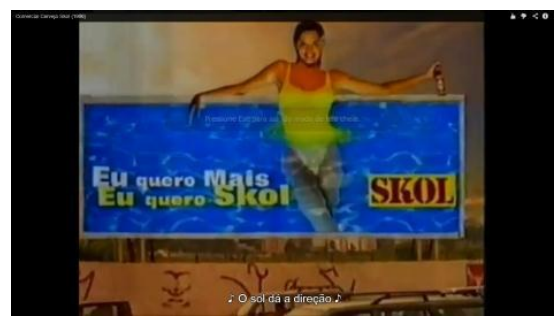

Figura 2 - Skol Eu Quero Mais 1996

Imagem: Ao final, ele mesmo se imagina no outdoor, mas suas duas mãos estão ocupadas. Ele levanta a mão direita, com o copo de cerveja, enquanto, com a esquerda, ele segura a garrafa. Então ele aproxima o copo do corpo e 
levanta as sobrancelhas.

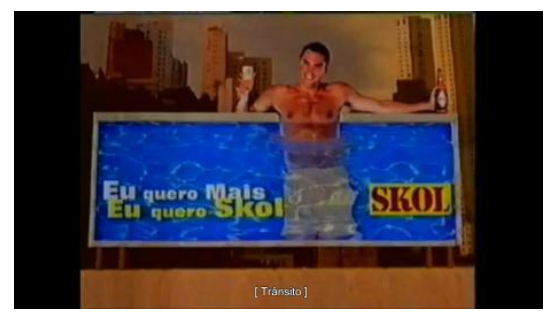

Figura 3 - Eu Quero Mais Skol 1996

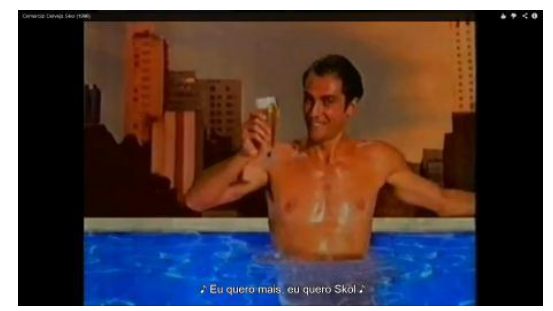

Figura 4 - Eu quero Mais Skol 1996

Percebemos fortemente a utilização da cor amarela na peça, a cor do biquíni, do short, do guarda-sol, das peças de banho da praia, numa relação entre o amarelo, o sol, a cerveja e a mulher, como na própria música diz: o sol dá a direção. Assim como percebemos também que o personagem masculino é mais ativo e parece dá a direção ao vídeo. Ele se coloca, ao final, no outdoor, o que sugere uma função semelhante à desenvolvida pela personagem feminina. No entanto, o fato dele está com as duas mãos ocupadas, parece remeter a uma espécie de consolo, já que ele não tem a mulher, tem a cerveja!

\section{Skol Alegria do Brasil, 1997:}

Imagem: Aparecem cenas de bar

Locução em off: Nós vamos mostrar para você, pela primeira vez na TV, graficamente, como se comporta uma cerveja, quando entra na sua garganta. Primeiro, a Skol. Ela desce redondo, acompanhada do ruído, Ah! Agora, outra cerveja. Ela desce quadrada, bem quadrada, acompanhada do ruído: Pup! Agora, amigo, é com você!

Imagem: Mostra cena de um homem tomando Skol, ao lado de uma mulher loira e a forma redonda descendo pela garganta dele e de outro homem 
tomando outra cerveja sozinho e uma forma quadrada descendo pela garganta. Locução off: Ah! da Skol e Pup! da outra cerveja.

Trilha: Dá pra ver no Ah! Que eu tinha que tomar. Skol desce mais redonda e não faz Pup! Redondo é Ah! Quadrado é Pup! Com Skol tem Ah! Se for outra é Pup! Mais uma Ah! Mais Cem, mais mil. Skol desce mais redonda pra alegria do Brasil.

Trata-se de uma peça direcionada ao público masculino, onde são os homens que tomam a cerveja e escolhem entre a quadrada - concorrente- e a redonda da Skol. O homem mais baixo e vestido de forma mais tradicional toma a cerveja quadrada, sozinho e o homem bonito, esbelto e descolado toma Skol acompanhado de uma loira ao lado.

\section{Skol Redondezas, 1998:}

Imagem: Dois homens estão na bancada de um bar de praia

Personagem Masculino 1: - Skol desce muito mais redondo, você sente isso quando você toma.

Personagem Masculino 2: - Cerveja é tudo a mesma coisa! Eu bebo e desce.

Personagem Masculino 1: - Você bebe e desce quadrado.

Personagem Masculino 2: - Você vai me dizer que essa cerveja

Imagem: O diálogo é interrompido por duas mulheres de biquíni, que entram entre os dois, no balcão do bar, uma de amarelo e outra de azul. Elas então pedem licença. Personagem masculino 1: "Nossa Senhora”, Oi!!!".

Imagem: Elas pedem duas Skol. Um dos homens está tomando Skol.

Personagem Masculino 2: - Você é daqui das redondezas?

Mulher de biquíni amarelo: - Sou, e você?

Personagem Masculino 1: - Oi, você é daqui das quadradezas?

Mulher de biquíni azul: - Quê?, estranhando a pergunta.

Personagem Masculino 2: - Você sabia que eu passei minha vida inteira rodando atrás de alguém como você?

Mulher de biquíni amarelo: - Eu também.

Personagem Masculino 1: - Sabe que eu passei minha vida inteira quadradando atrás de alguém como você? 
Mulher de biquíni azul: Tá louco?!

Personagem masculino 2: Vamos dar uma voltinha?

Mulher de biquíni amarelo: Vamos!

Personagem Masculino 1: Vamos dar uma quadradrinha?

Mulher de biquíni azul: Idiota! E dá um tapa na cara do pretendente.

Locução off: Skol, a cerveja que desce redondo!

Percebe-se que os dois homens usam cor azul, o bem-sucedido na paquera usa uma blusa azul e o que é mal sucedido tem uma toalha azul pendurada no pescoço, então entram as duas mulheres de biquíni, uma de amarelo e a outra de azul. Numa relação de comparação entre o azul (a forte concorrente na época Antarctica) e o amarelo da Skol. A de biquíni amarelo "desce redondo" e vai dar uma voltinha, a de biquíni azul, desce quadrado e vai embora chateada com a pergunta do personagem que bebe cerveja quadrada. Nesta peça temos a comparação como tema fundamental, a cerveja que desce redondo, conquista a mulher que está de amarelo, numa associação com o próprio leiaute da cerveja Skol. Já a que desce quadrada não produz o efeito de sucesso como a Skol, ou seja, o sujeito não somente é tratado como ridículo, como ainda leva um tapa na cara ao final da tentativa de sedução. Esta publicidade então faz relação entre a cerveja que desce redondo, a Skol, como aquela que o homem leva a mulher para dá uma voltinha; e também com a que desce quadrado, pois o outro homem não dá voltinha com a mulher e leva um tapa no rosto. Ele fica chateado, sem graça e olha para o copo de cerveja. A conclusão é: Skol a cerveja que desce redondo!

\section{Skol Bunda Quadrada, 1998:}

Imagem: Homem está na praia e pede uma cerveja, o garçom dá então uma que desce quadrada pela garganta e ele passa a ver tudo na praia de forma quadrada, os guarda-sóis, o sol, os pneus da bicicleta, aí ele olha, vem uma mulher loira de biquíni amarelo, ele então vê seus seios e bunda quadrados, então ele retorna ao bar.

Homem: - Garçom, pelo amor de Deus, me dá uma Skol urgente!

Imagem: Então tudo muda. Passa para cenas de um bar onde todo mundo está feliz, com cerveja Skol na mão. 
Trilha: O verão chegou, olha Skol na minha mão, Skol desce mais redondo, a redondinha do verão. $(2 \mathrm{x})$

Imagem: Entra uma loira vestida com um top branco curto, de barriga a mostra e calça justa, segurando um copo de cerveja. Os homens olham para ela, ao passar, eles olham para o bumbum da mulher e aparece o símbolo do redondo no bumbum da mulher.

Locução em off: Skol desce redondo!

Nesta peça vemos a relação entre o redondo e as formas do corpo da mulher. Primeiramente, o rapaz que bebe a cerveja quadrada, ao ver tudo quadrado, resolve mudar de escolha da cerveja somente ao ver os seios e o bumbum da mulher loira virarem quadrados. Depois a clara relação que eles fazem entre o bumbum da mulher loira no bar e o símbolo da Skol, a seta redonda.

\section{Skol Praia -2000:}

Trilha: Ao som da trilha sonora de Without you de Mariah Carey.

Imagem: Encontro na praia de um ser extraterrestre e uma loira de biquíni amarelo. A cena inicial mostra os dois correndo na praia. Eles se encontram, dão as mãos e rodopiam na areia. A loira então coloca o ET nos braços e rodopia mais. Então aparece o ET com a lata de cerveja Skol na mão e a loira em cima de um pé de côco sorrindo. Ela beija a cabeça do ET e eles dão as mãos. Eles se olham, ela faz massagem nas costas do ET, aparecem duas latinhas de cerveja Skol, ela segura uma latinha e encosta na bochecha. Então eles se beijam. Anoitece, aparece então uma nave espacial estacionada na praia, em trepidação.

Locução off: Dois, redondo, redondo, redondo. O verão mais Skol do milênio, Imagem: Aparece um coração amarelo com o ano 2000 na frente, conforme a figura 5 . 


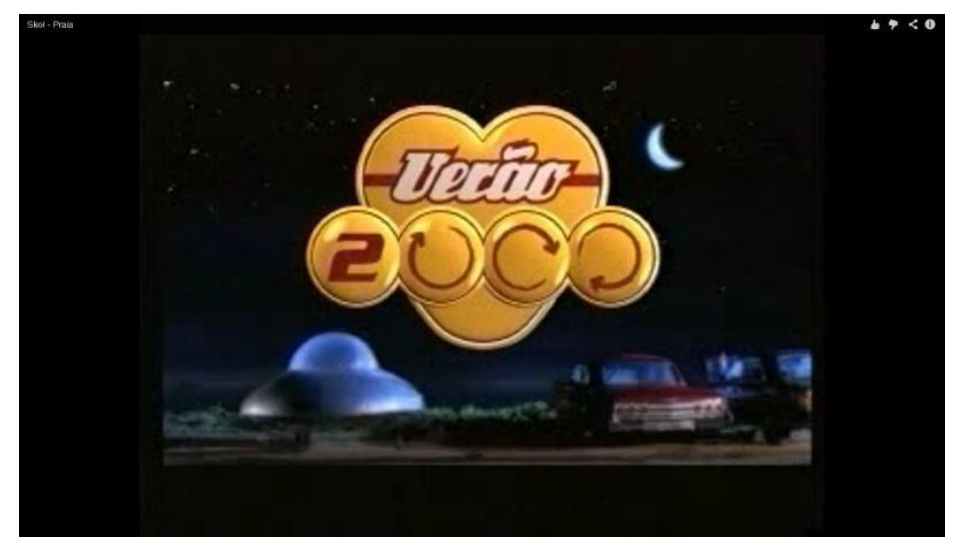

Figura 5 - Skol Praia 2000

Esta narrativa mostra um clima romântico entre uma loira e o ET. A associação entre a cerveja que desce redondo e a mulher continua no alvo. Um ser estranho como o ET e a loira em clima de paquera, remete a uma cruel associação, para homens e mulheres, de que com a Skol na mão até um ET é capaz de conquistar uma loira e que, por isso, o verão do ano 2000 é o mais redondo do milênio. Com a Skol tudo será redondo até para o ET.

\section{Skol Banheiro 2000:}

Imagem: Dois homens no banheiro fazendo xixi. Um deles tem dificuldade para urinar, faz esforço e dá uns gritinhos. Ao sair a urina, ouve-se som de gelo caindo no copo. O rapaz ao lado estranha.

Homem em dificuldade fala: Tinha acabado a Skol!

Imagem: Entra cenário de um bar.

Trilha: Skol desce mais redondo do início até o fim!

Neste vídeo o foco é a associação do desce redondo da Skol com o processo fisiológico masculino, indicando que quem não toma a Skol sofre. A linguagem desta peça é direcionada ao público masculino e composta de um cenário habitual do mundo dos homens, um banheiro, onde o comparativo feito entre eles, na situação, é da forma que o xixi desce.

\section{Skol Pequenininho 2001:}

Imagem: Abre a cena com um casal deitado na cama. O homem toma um gole de cerveja Skol e a mulher-sereia loira também. Ela continua segurando o copo 
de cerveja na mão.

Homem: - Vamos até um bar tomar uma Skol?

Mulher sereia: - Mas, tá cheio de Skol em casa!

Homem: - Eu sei, mas não tem amigo nenhum para eu contar.

Imagem: Aparecem os amigos em um bar na praia, de um lado, e as amigas da sereia, do outro lado.

Amigo: - Ih, olha lá, acho que ela tá contando tudo também.

Imagem: Elas conversam, enquanto a sereia mostra com um gesto juntando os dedos das mãos o tamanho de um peixe pequeno que estava nas rochas. $\mathrm{O}$ grupo de amigos começa a rir e zoar do homem.

Homem: - Não, não, deve ser outro assunto.

Locução em off: Skol!

Nesta narrativa o homem apresenta a necessidade de ir ao bar mostrar a sereia aos amigos e contar vantagem. Mas, quando a sereia gesticula sobre um tamanho pequeno (no caso, do peixe), os amigos associam a ação ao tamanho do pênis do colega e passam a "zoá-lo". Numa relação bem humorada em que o feitiço virou contra o feiticeiro, a publicidade retrata o tema do orgulho masculino em contar conquistas aos amigos e mostrar a virilidade ao conquistar uma bela mulher, no entanto, do ponto de vista do grupo de amigos, a sereia dá o troco dizendo que é pequeno. Por fim, a peça não falava a respeito da virilidade masculina, mas acabou por apresentar o medo masculino em se ter o pênis pequeno e a importância dessa avaliação feita pelas mulheres, para os homens. Neste caso, também podemos perceber como o homem é reduzido à existência de um pênis, ao falo, que não pode falhar, nem ser pequeno.

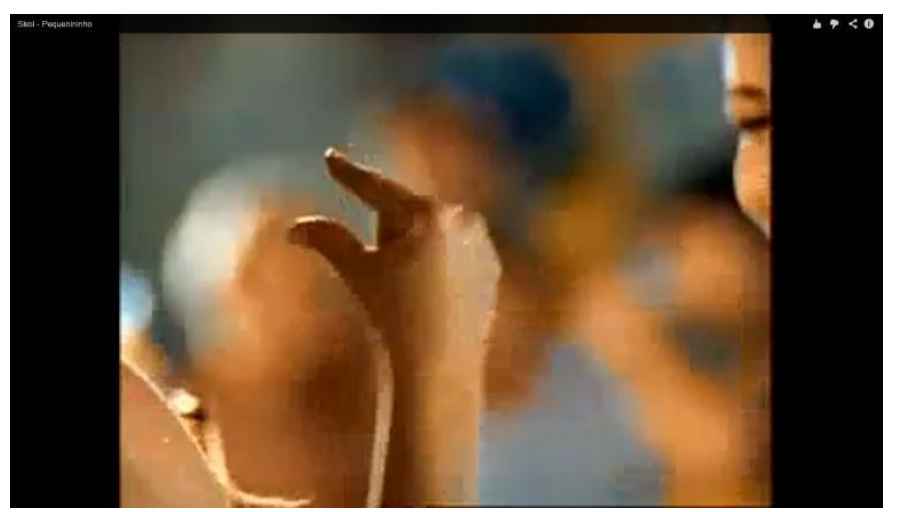

Figura 6- Skol Pequenininho 2001 


\section{Skol Dona Carminha 1 - 2001:}

Imagem: Um personagem masculino vai se consultar em um oculista. $\mathrm{O}$ médico faz um exame de vista, mostrando várias formas redondas, de cor amarela.

Médico: Que forma geométrica você vê?

Personagem masculino: Um quadrado.

Imagem: Então, o médico chama D. Carminha.

Médico: - D. Carminha, por favor, mostre os seios. D. Carminha é pelo bem da ciência!

Imagem: Então a mulher abre a camisa e mostra os seios.

Médico: O que o senhor está vendo?

Personagem masculino: - Dois quadrados.

Médico: - Ok, beba essa Skol!

Imagem: O rapaz bebe e, após confirmar ver redondo uma das formas geométricas, sorri, olhando para de D. Carminha.

D. Carminha: - Não, ah não! Ele já está curado.

Trilha: Redondooo!

Imagem: Cenário de bar, Dona Carminha passa pelos rapazes.

Rapaz: - Vai D. Carminha pro bem da ciência!

O vídeo em questão mostra uma mulher loira que mostra os seios para o homem que está com problemas de visão. D. Carminha mostra os seios "pelo bem da ciência", e após tomar a cerveja Skol, o personagem masculino resolve o problema e passa a ver os seios femininos de forma redonda. Mais uma vez acontece a associação entre o desce redondo da Skol e as formas corporais femininas, no caso, os seios de D. Carminha.

\section{Skol Dona Carminha 2:}

Imagem: O paciente está sentado na cadeira de exames oftalmológicos, com lentes de aumento nos olhos.

Médico: - O senhor toma Skol, não toma?

Paciente: - Tomo

Médico: Então o senhor não tem nada. 
Paciente: - E o senhor acha que eu viria aqui se eu não tivesse nada?

Médico: - Ok, que forma é essa?

Imagem: Médico mostra um círculo amarelo

Paciente: É um losango.

Médico: E essa?

Imagem: Médico mostra uma bola amarela.

Paciente: - Um pentágono quadrado.

Médico: - O senhor não tem nada.

Paciente: Pô, peraí, e a Dona Carminha?

Trilha: Entra música envolvente.

Médico: - D. Carminha está de férias. D. Lulu?

Trilha: Música para.

Imagem: D. Lulu, que é gorda, abre uma cortina.

D. Lulu: - Oi!

Paciente: -Redondo, redondo, redondo.

Imagem: Cenário de bar

Trilha: Redondo, Skol desce mais redondo do início até o fim.

Imagem: $\mathrm{O}$ paciente encontra com D. Lulu no bar que acena para ele, interessada. O rapaz também encontra com D. Carminha no bar.

Paciente: - D. Carminha volta de férias, pelo bem da ciência!

Imagem: D. Carminha ri, segurando o copo de cerveja na mão.

O vídeo Skol Dona Carminha 2 é um desdobramento do primeiro vídeo, mas nesta peça, além da associação entre o redondo da Skol, existe a diferenciação entre a mulher gorda e a magra. O personagem masculino rejeita a atendente D. Lulu porque ela é gorda e ainda pede que D. Carminha volte, pelo bem da ciência.

\section{Skol Mulher loira paquera homem burro 2002 (Série de vídeos 1, 2 e 3):}

Imagem: Neste vídeo uma mulher loira de biquíni amarelo gesticula, na praia, perguntando ao homem que está do outro lado, se ele quer tomar uma Skol com ela. E ele não entende o gesto, então aos poucos outras pessoas ajudam a mulher na mímica, até a praia inteira ficar tomada por pessoas que repetem o gesto, juntamente com a loira que convida o homem para tomar uma cerveja. O homem 
mesmo assim não entende.

Trilha Sonora: Som das ondas do mar

Este vídeo, na verdade, é uma sequência de quatro vídeos. A cada vídeo, mais pessoas se juntam à loira, para explicar o gesto do convite para tomar uma Skol. A ideia de uma mulher loira linda chamar um homem feio e burro para tomar uma Skol parece associar a ideia de que quem toma Skol é inteligente e, além disso, é bonito, no caso, bonita. Também existe uma diferença geracional entre a jovem mulher que propõe ao homem mais velho tomar uma Skol juntos.

\section{Skol Ilha Quadrada x Ilha Redonda 2003:}

Locução em off: Ilha quadrada, 45 dias tomando cerveja quadrada.

Imagem: Mostra duas barracas de campo, separadas com plaquinhas: rapazes moças. Abre imagem de grupo na praia.

Grupo canta: Nós somos jovens, jovens, jovens, somos do exército, exército do surfe. Homens de um lado, mulheres de outro.

Homem: Ilha, nunca me diverti tanto!

Imagem: Mostra a Ilha redonda, onde se bebe cerveja Skol, e uma festa alegre, com todo mundo misturado, dançando e, várias mulheres sorrindo, de biquíni.

Trilha: Uhuuu, Skol!

Locução em off: Aprecie com moderação.

A situação aqui parece remeter ao julgamento segundo o qual quem não toma cerveja Skol vira careta, tão careta que rapazes ficam de um lado e moças, de outro. As roupas na ilha quadrada são compostas e sem estampas, enquanto na ilha redonda são coloridas, estampadas. Nela, as mulheres aparecem usando biquíni. Quem comanda a música que anima a festa na Ilha redonda é uma mulher de biquíni. Na ilha redonda, o amarelo da Skol aparece em abundância.

\section{Skol Casamento 2004:}

Imagem: Durante o casamento, os noivos estão no altar, diante do padre.

Noivo: - Eu, Antônio, prometo ser...,: Peraí, eu preciso saber de uma coisa antes, se ela promete ficar gostosa pra sempre?

Noiva: Como? 
Noivo: - Não, é porque, por exemplo, eu sou fiel à Skol, Skol é gostosa não muda nunca!

Imagem: Os presentes no casamento fazem burburinho e se entreolham.

Noivo: - Peraí, gente eu só tô perguntando se vai ser gostosa. A mãe, por exemplo, ficou um bucho.

Imagem: A noiva desmaia. O marido da mãe sorri.

Locução em off: Quando a situação é quadrada, Skol a cerveja que desce redondo!

Imagem: Abre cena do noivo e um amigo no bar tomando cerveja.

Amigo: - Não, falou pouco, mas falou bonito!

Imagem: Créditos dizendo Aprecie com moderação.

Este vídeo associa a cerveja com a mulher gostosa. Podemos até dizer que esta associação faz relação direta entre a mulher e a cerveja, quando o noivo fala que precisa saber se a noiva promete ficar gostosa pra sempre, porque a Skol é gostosa e nunca muda.

\section{Skol Mulheristicamente 2004:}

Imagem: Aparece uma televisão mostrando um vídeo que demonstra como a Skol desce redondo pela garganta e mostra um rapaz tomando Skol. Ao tomar um gole de cerveja uma mulher de biquíni amarelo desce redondo por sua garganta. Locução em off: Veja como a Skol desce na sua garganta. Ela desce redondo, gostosa, bem gostosa! Agora outra cerveja.

Imagem: Mostra um homem gordo de biquíni amarelo, descendo quadrado pela garganta de outro rapaz.

Locução em off: Ela desce quadrada, bem quadrada.

Imagem: Mostra um casal em sua residência, e a mulher, que está de pé enxugando pratos.

Mulher: - Porque eles sempre dão um jeito de enfiar mulher gostosa em propaganda de cerveja hein?

Marido: Ah é?! Nem reparei! Eles colocaram homem também amor só que não ficou bom, né?

Imagem: Ela então joga uma torta no rosto dele. 
Imagem e locução em off: Aprecie com moderação.

A publicidade coloca em questão o incômodo da mulher em sempre aparecer mulher gostosa nos vídeos de cerveja, no entanto, eles continuam a mostrar a mulher na associação desde redonda, desce gostosa. A mulher ao final joga uma torta no rosto do marido em revide, mas no fundo a questão que parece levantar é que as mulheres se incomodam, mas os homens gostam de ver mulher gostosa mesmo e, que ao colocar os homens nos enredos, eles parecem fora de contexto assumindo um papel que não é deles. Por outro lado, o homem cabeludo e gordo de biquíni amarelo, aparece numa posição de ridicularização e inadequação, também remetendo à troca de papéis entre homens e mulheres.

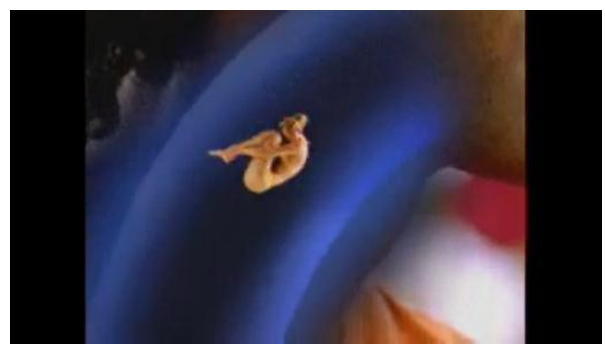

Figura 7 - Skol Mulheristicamente 2004

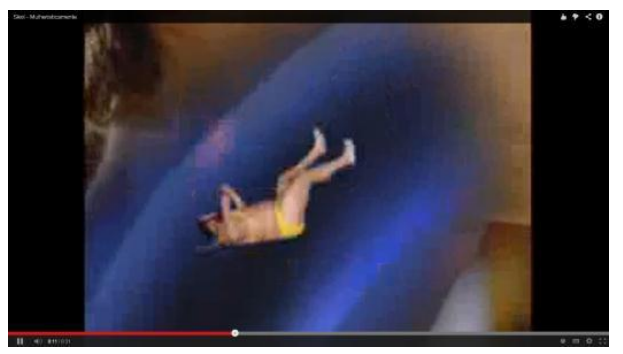

Figura 8 - Skol Mulheristicamente 2004

É importante lembrar que em 2003, o Conar reelaborou o Código Brasileiro de Autorregulamentação Publicitária, o que pressupõe um incômodo da sociedade em relação à regulamentação da publicidade brasileira. Então a crítica que aparece em questão nesse vídeo é também perpassada por este contexto e, portanto, vemos um item de inovação no filme que apresenta este diálogo, abordando a discussão dentro do próprio e para quem o assiste, no entanto, de forma debochada. 


\section{Skol Será 2005:}

Imagem: O rapaz está no supermercado, escolhendo cerveja. Ele segura uma cerveja quadrada.

Rapaz: - Se eu levar esta, será que vou ser bem ou mal recebido no churrasco?

Imagem: Rapaz se imagina chegando no churrasco e todo mundo correndo para longe e gritando.

Rapaz: - Será? Será?

Imagem: - Aparece então um homem baixinho na frente dele enchendo o carrinho com Skol.

Baixinho: - Será, Será?

Imag em: Mostra o baixinho chegando no churrasco e todo mundo correndo pra cima dele, mulheres servindo cerveja para ele no copo, balançando ele na rede e beijando suas bochechas.

Baixinho: - Verão com Skol redondo será!

Caracteres: Aprecie com moderação!

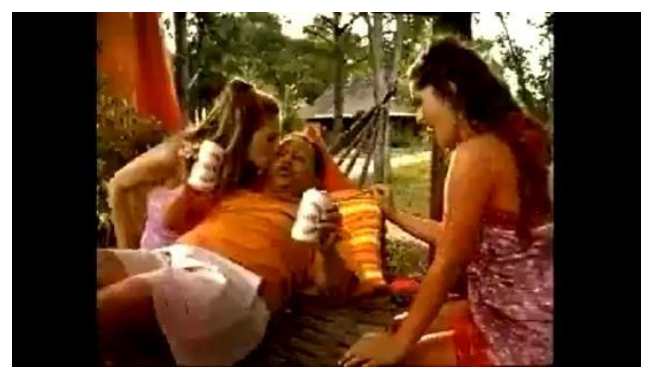

Figura 9 - Skol Será 2005

Neste vídeo apresenta-se todos os benefícios de escolher Skol e, incluindo boa receptividade, aconchego e regalias por parte das mulheres, como fazendo parte do kit Skol, enquanto, ao escolher a cerveja quadrada, todas essas consequências seriam excluídas.

\section{Skol Tubarão 2005:}

Imagem: Tubarões na água, arrodeando um banhista de gênero masculino.

Personagem masculino: - Se o cara que inventou a Skol tivesse inventado o tubarão ele não seria assim, ele seria assim.

Imagem: Tubarões viram mulheres lindas, de biquíni amarelo, apenas com as 
barbatanas nas costas. Saem da praia então um monte de tubaroas e um tubarão servindo Skol às pessoas que estão na praia.

Locução em off: Com Skol o verão fica redondo.

Imagem: Mostra um homem-tubarão amarrado pelos pés e pendurado de cabeça para baixo, segurando uma bandeja com uma garrafa da Skol. Pescador posa para foto ao lado do tubarão.

Pescador: Tá gelada?

Neste vídeo existe a referência de que quem inventou a Skol iria criar tubarões à moda Skol, ou seja, mulheres gostosas. Ao sair um monte de tubarões da praia servindo as pessoas, observamos que apenas um era do gênero masculino, os demais eram do gênero feminino. Além disso, no final da narrativa, o pescador pega esse tubarão e o coloca de cabeça para baixo, imobiliza-o. Mesmo assim percebemos que, além de todas as mulheres tubaroas, aparece um homem tubarão que é garçom, de sunga, o que parece ser um contraponto, no entanto, majoritariamente, as tubaroas reinam no mar, e ao final, este tubarão é amarrado e serve a cerveja, numa situação de humor.

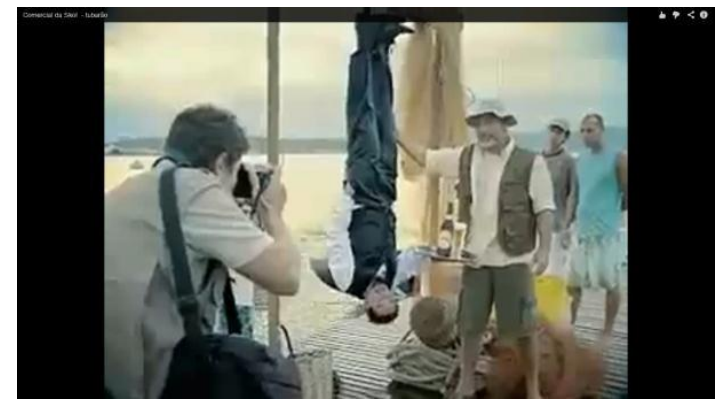

Figura 10 - Skol Tubarão 2005

\section{Skol Ah o Verão 2006:}

Imagem: Mostra várias situações do verão como: um beijo entre um homem e uma mulher, em cambalhota, no ar; homem vestido de galo, homens carregando uma grade de cerveja na praia, homem vestido de galo surfando, outro pulando numa piscina, outros dois empurrando um pneu de caminhão, no campo, uma Kombi lotada de gente, um casal de noivos de beijando e pulando em um rio e depois de big jump, um homem com a cabeça enterrada na areia da praia, homens levando um barco na cabeça, pulando de paraquedas, homem vestido de 
flor, homem de sunga pulando em uma piscina pequena, já cheia de pessoas, homens: dançando, tomando cerveja, comendo um sanduíche enorme, beijando uma boneca inflável, dando cambalhotas na praia, tirando brincadeira com mulher no supermercado, jogando futebol na praia, encostando uma cerveja gelada nas costas de uma mulher loira.

Locução em off: Ah o verão! Dizem que é a estação da perdição. É porque é o no verão que você faz tudo aquilo que vai contar para os seus netos, bisnetos e tataranetos um dia. É no verão que o amor floresce, o amor à preguiça, amor ao sol, ou até mesmo amor a uma sirigaita, ou a uma dúzia de sirigaitas. Por que não? Seja otimista, rapaz, vai contar o quê para o neto? Que ficou jogando o dominó, não! Vai contar que pulou da pedra, comeu churrasco, deu cambalhotas, essas coisas que a gente só faz no verão. Ah o verão. O verão é agora! Tá redondo? Yeah, Yeah!

Trilha: Música instrumental alegre.

Neste vídeo pudemos observar que a maioria das ações foram empreendidas pelos homens. Apenas em duas situações as mulheres aparecem exclusivamente fazendo alguma atividade: surfando e jogando futebol. Exceto nesses momentos são os homens que fazem todas as outras atividades, as mulheres aparecem em outras situações, em situação relacionada aos homens, no beijo e no supermercado, quando os meninos tiram gracinha com a mulher na fila do supermercado. Além disso, percebemos que a linguagem é direcionada aos homens como, por exemplo, em: Seja otimista, rapaz!

\section{Skol Musa do Verão 2006:}

Locução em off: Musa do verão 2006, palmas pra ela.

Imagem: Aparece a atriz desfilando na passarela, de biquíni amarelo.

Personagem masculino: - Se o cara que inventou a Skol tivesse inventado a musa do verão, ela não seria assim. Seria assim.

Imagem: Aparece um monte de seguranças impedindo que os homens toquem na musa e ela sendo clonada e entregue por serviço de entrega nas casas dos bebedores de Skol.

Entregadores: - Sua musa do Verão! 
Imagem: Os homens ficam enlouquecidos, os entregadores chegam no bar.

Entregadores: - Olha a musa pra todo mundo!

Imagem: Aparece um homem com uma musa do verão com bigode.

Homem: - Justo a minha veio com defeito?

Locução em off: Com Skol o verão fica redondo!

Caracteres: Se beber não dirija!

Imagem: Um senhor idoso recebe uma musa do verão.

Idoso: - É importada?

Numa clara associação entre a mulher e o produto, a mulher é clonada, ou seja, produzida em grande escala e entregue em domicílio, pelo serviço de entrega. Alguns consumidores empreendem reclamações em relação ao produto-musa, como o que lamenta a musa dele ter vindo com bigode. $\mathrm{O}$ outro senhor idoso, ao final, pergunta se a musa é importada, o que remete novamente à comercialização da musa e a uma forte associação entre a mulher e a cerveja. Além disso, os únicos beneficiados pelo produto-musa são os homens.

\section{Skol Mulher de Amigo 2007:}

Imagem: No cenário de um bar, amigos jogam sinuca e conversam.

Amigol: - Bom, Cacá vai trazer a namorada aí!

Amigo2: - Disse que é linda, cara.

Amigo3: - Parou, mulher de amigo meu para mim é homem!

Imagem: Chegam Cacá e a namorada loira.

Amigos: - É homem! É homem!

Imagem: A namorada vira um homem forte, de peruca loira e vestido preto. Cacá:

- Oi galera, essa é a Jú!

Amigo 1: - Como é que é, meu irmão!

Amigo 2: - Fala aí cumpade!

Imagem: A namorada pega a cerveja de um dos amigos.

Amigo 2: - Ôooo

Imagem: Amigo dá um tapa na cabeça de Jú (a namorada).

Amigo 2: - Essa Skol aqui é minha!

Amigo 1 e 3: - Que é isso, cara?! 
Amigo 2: - Ué mulher de amigo meu, que pega minha Skol, para mim é homem!

Namorada: - Mal educado!

Amigo 1 e 3: - Cara grosso, rapá!

Locução em off: Entra locução: Skol, tá na roda, tá redondo! Se beber não dirija!

Nesta situação, a peça publicitária se utiliza do ditado popular que diz: Mulher de amigo meu para mim é homem, de forma bem humorada, para tratar a questão. Desta forma, Brinca com a situação em que uma bela mulher se torna homem somente por ser mulher de amigo meu. Trata-se de um acordo intrínseco ao mundo masculino e que nesta narrativa é abordado de forma interdita, pelas próprias regras estabelecidas pelo mundo masculino.

\section{Skol Choque em geladeira 2007:}

Imagem: A primeira cena tem foco em reportagem mostrada na televisão onde é apresentada uma experiência com ratos.

Locução em off: A experiência mostrou que os camundongos, mesmo ao levarem choque elétrico, retornam ao alimento. É que, como a experiência é boa, eles se esquecem da experiência ruim.

Imagem: Mostra um grupo de 5 mulheres sentadas no sofá.

Mulher: - Que estúpido né?

Imagem: Na cozinha um grupo de 5 amigos bebem Skol.

Amigol: - Vou pegar uma Skolzinha.

Imagem: Ao abrir a geladeira, ele toma choque

Amigo 1: -Isso aqui tá dando choque, sabia?

Amigo 2: - Eu também quero!

Imagem: $\mathrm{O}$ amigo 2 abre a geladeira e também leva choque.

Amigo 2: - Isso aqui tá dando choque, sabia?

Amigo 3: - Pega uma pra mim aí?

Amigo 2: - E por que eu não pegaria?

Imagem: $\mathrm{O}$ amigo 2 abre a geladeira e grita, ao levar choque novamente, mas pega outra cerveja.

Amigo 1: - O que foi, rapaz?

Amigo 2: - Ah, tomei um choque, responde. 
Amigo 4: - Que choque que nada

Imagem: Amigo 1 abre a geladeira.

Amigo 1: - Pô por que você não conserta isso, hein?!

Amigo 2: - É que eu esqueço.

Amigo 1: - Esquece o quê?

Imagem: Amigo 1 abre a geladeira novamente e leva mais um choque.

Amigol: - Lembrei!

Imagem: Todos riem.

Locução em off: Skol tá na roda, tá redondo!

O vídeo faz uma nítida associação dos homens com os ratos, pois os ratos retornam ao alimento, mesmo levando choque, e os homens continuam bebendo Skol, mesmo levando choque. Uma crítica que parece vir reforçada pela conclusão das mulheres na sala: Que estúpido, né?! No entanto, seus amigos estão fazendo o mesmo na cozinha. Enfim, ao mesmo tempo que critica os homens, critica as mulheres que não percebem que os homens têm a inteligência de um camundongo, portanto, parece ser uma crítica relacional. No entanto, o que entra em debate é o que vale mais a pena, levar um choque e ter uma experiência boa ou apenas concluir que é uma estupidez sem experimentar? O tom da peça é de muito humor.

\section{Skol Cartório 2008:}

Imagem: Ambiente de cartório.

Recepcionista: - Próximo! O noivo veio?

Noivo: -Eu,

Recepcionista: E a noiva?

Noiva: - Eu

Recepcionista: - Testemunha?

Testemunha: - Sou eu.

Recepcionista: - Olha, aqui tem 61 casais na frente, aguarda?

Imagem: Os noivos lamentam.

Testemunha: Ei, vamos armar um boteco?

Noivos: - Redondamente!

Imagem: Corta a cena e aparecem cenas de bar e Skol gelada.

Trilha: Onde tem Skol, tem curtição. Vamos armar um boteco aí. Se tem Skol tem 
curtição!

Imagem: Passa uma loira de vestido, ela se abaixa para pegar uma Skol e o noivo olha fica olhando. A noiva não gosta e dá uma tapinha no noivo, chamando sua atenção.

Noiva: Plínio?

Noivo: - O que foi, amor, tava olhando a Skol ali.

Testemunha: - Sou testemunha!

Locução em off: Skol tá na roda, tá redondo.

Caracteres: Se beber não dirija!

O vídeo faz uma analogia entre o casamento e a curtição. A testemunha do casamento é a testemunha que defende o homem da acusação de olhar para a mulher alheia. O noivo ao olhar para a loira de vestido justifica-se dizendo que estava olhando para a Skol e não para a mulher. A noiva retruca, mas em um ambiente de curtição, parece fazer sentido, pois se tem Skol, tem curtição, como a própria música diz.

\section{Skol redondo é rir da vida 2009:}

Imagem: Um casal está sentado na grama. Um deles está de costas e tem cabelo comprido. Ao virar o rosto, revela ser homem. Em outra situação, aparece um homem em cima dos ombros de outro, para olhar uma mulher se trocando, no quarto. Mostra um homem dividindo uma Skol com outro, no bar, e um casal de amigos no proctologista, dando força um para o outro. Passa um casal de amigas assistindo um streep e um espetáculo de balé. Também mostra um enterro e um homem consolando a mulher e olhando pros seios dela. E um aniversariante ganhando o mesmo presente do ano passado. Aparece a situação de uma traição e um homem dando apoio à traição do outro. Duas amigas se encontram numa festa usando o mesmo vestido.

Locução em off: Parece um casal romântico, mas não é! Parece uma dupla de equilibrista, mas também não é Nós somos amigos! Nós nunca sabemos quando começa uma amizade, nem sabemos onde ela vai nos levar! Nós temos amigos porque precisamos confiar em alguém. Ficamos juntos nas horas boas e nas 
roubadas. Existe amizade entre homem e mulher? A velha pergunta! Não, a velha resposta. Fazemos vaquinhas de aniversários. Nos protegemos uns dos outros e abusamos da intimidade, nos odiamos às vezes. Somos inexplicáveis, mas quem não tem amigos? Não tem nada! Porque redondo é rir da vida. Skol a cerveja que desce redondo!

Caracteres: Se for dirigir não beba.

Apesar de apresentar situações de amizade, esta narrativa se desenrola sob o ponto de vista masculino sobre a amizade. Notamos que, ao tratar da situação em que a mulher aparece, ela ou fica chateada porque a outra está usando o mesmo vestido que ela, ou é enganada pelo namorado que a traía. Também apresenta uma situação em que as amigas assistem a um streep. Além disso, percebemos que é abordada uma perspectiva da masculinidade hegemônica: os homens que parecem ser namorados, mas não são; não existe amizade entre homem e mulher; o outro que tem medo de ir ao proctologista; aquele que trai e é ajudado por outro amigo; os caras que espiam a mulher trocando de roupa.

\section{Skol Churrasco 2009:}

Imagem: Mostra um homem segurando um espeto. A sombra de um homem com uma faca, fazendo movimento de subida e descida com o braço. Sobe uma cortina e mostra a cena de um homem cortando a carne no jardim. Mostram 3 homens no supermercado.

Personagem masculino 1: - Quem pegou a carne?

Personagem masculino 2: - Ué, eu peguei Skol.

Personagem masculino 3: Eu também!

Imagem: Aparece a carne muito seca caindo no prato e, na outra situação, a carne espirrar sangue na parede ao ser cortada.

Churrasqueiro: - Olha a maminha da Luiza.

Imagem: Churrasqueiro serve a carne para um grupo de amigos do churrasco, entre eles Luiza.

Churrasqueiro: - Olha a chuleta da Vivi.

Imagem: As mulheres da mesa não acham graça. Mostra uma churrasqueira 
pegando fogo e um rapaz recusando o doce. Aparece a Vivi de biquíni servindo um rapaz na piscina e um homem pegando uma Skol.

Homem: - Dá licença.

Imagem: Homem tira a Skol da mão de outro que trouxe cerveja quadrada. Aparece uma mulher gordinha comendo carne e mostra um rapaz pulando na piscina.

Locução em off: Parece luta de espada, mas não é. Parece filme de terror mas também não é. É dia de churrasco! Primeiro nós vamos às compras. Depois chega o grande dia, ou nós somos da turma do bem passado, ou da turma do mal passado. Fazemos trocadilhos infames. Provocamos incêndio. Fazemos receitas secretas, sobremesa, não aceitamos. Mas aceitamos outra fraldinha, outra picanha, outra chuleta da Vivi. Mas tem sempre um Mané que traz cerveja quadrada e depois quer tomar Skol. E por mais que a gente se esforce, no final sempre sobra. Churrasco é isso aí. Perturbamos vizinhos, saímos da dieta, recebemos visita, não importa! Domingo que vem tem mais, porque redondo é rir da vida. Skol, a cerveja que desce redondo.

Caracteres: Se for dirigir não beba.

Neste vídeo percebemos a associação entre os cortes das carnes e as mulheres e da ação empreendida pelos homens. Eles são os autênticos churrasqueiros, são tão churrasqueiros que não aceitam sobremesa.

\section{Skol Litrão e Beto Barbosa - Carnaval 2010:}

Locução em off: Skol ensina como queimar o filme no churrasco.

Imagem: Um personagem masculino chega no churrasco, vestido de bermuda e blusa. Vão sumindo as peças que o personagem estava vestindo e surgindo as que são mencionadas na locução em $o f f$.

Locução em off: É só chegar de sunga de crochê, pochete, blazer de ombreira, óculos new wave, ensaiando passos de lambada, na ilustre companhia do Beto Barbosa.

Imagem: Entra o cantor Beto Barbosa.

Trilha: Beto Barbosa canta: Adocica meu amor, adocica, adocica.

Locução em off: Mas pra fazer bonito também é fácil. 
Imagem: Personagem masculino abre a mão e a cerveja tamanho litrão surge em cima dela.

Locução em off: Skol litrão, muito mais Skol pra dividir com os amigos!

Imagem: Entra personagem feminina.

Personagem feminina: - Beto Barbosa!

Beto Barbosa: - Eu!.

Personagem feminina: - Me apresenta seu amigo aí.

Imagem: Personagem feminina olha por trás do personagem masculino e sorri.

Locução em off: Se for dirigir não beba!

Aqui o uso do grotesco e da brincadeira de carnaval tomam conta do vídeo na descontextualização da lambada no carnaval, assim como em alguns elementos do vestuário do personagem masculino em questão. Esse personagem é ruivo, o que pode remeter a associação entre o exótico, o diferente. Além disso, a ênfase no tamanho da cerveja é elucidada pelo exagero das vestes do personagem. Ao final da narrativa, a mulher mostra-se interessada em conhecer o rapaz ruivo que balança as sobrancelhas para cima.

\section{Skol Carnaval 2011:}

Trilha Sonora: Música Adocica, lambada de Beto Barbosa.

Imagem: Em frente a um trailer, o personagem vestido de sunga de crochê, ponchete, blazer verde e óculos new wave dança movendo os quadris para frente e para traz. Aparece também um quarteto de argentinos que também dançam, mas sambando, e uma senhora que dança com outra, pregando um adesivo em sua testa. Depois entra um senhor de bengala na dança. Um chinês de sunga também dança. Chinês: - Ah, dois palitos ah.

Imagem: Entra Beto Barbosa cantando e dançando lambada. E surge um personagem chamado Cabelo dançando. Ao final, todos os personagens se juntam e continuam dançando.

Locução em off: No carnaval é um por todos e todos por uma! Se for dirigir não beba.

Esse vídeo apresenta o momento do carnaval como algo divertido, no qual 
todos se encontram para dançar, de forma engraçada e bem humorada.

\section{Skol Terremoto 2011:}

Imagem: Quatro amigos estão na praia tomando Skol, quando começa o terremoto que suga a idosa, o turista, a gostosa e o cachorrinho. Ao sugar a Skol, os amigos se jogam na fenda aberta pelo terremoto e vão parar num lugar quente.

Locução em off: Skol, um por todos e todos por uma!

Imagem: Mostra o cenário que parece uma praia, com presença majoritária de mulheres, mas com um magma quente.

Amigo: - Legal aqui né! Vai um peixinho na brasa?

Neste, apesar das condições adversas, o ambiente proporcionado pelo terremoto não é muito diferente do da praia, pois tem Skol e mulheres. O terremoto suga a idosa, o turista, a mulher e o cachorrinho, mas não sugou os amigos. Eles foram porque quiseram.

\section{Skol $360^{\circ}$ Churrascabilidade 2011:}

Imagem: As pessoas incham ao tomar cerveja quadrada durante o churrasco, virando baiacús. Um rapaz fala com alguém pelo celular.

Rapaz baiacú: - Não vai dar, estou preso aqui.

Locução em off: - Já com Skol $360^{\circ}$ não estufa, nem empapuça, porque ela é produzida por um processo de fermentação $360^{\circ}$. Skol $360^{\circ}$, a cerveja com bebabilidade.

Imagem: Rapaz, em um churrasco da Skol, falando ao celular.

Rapaz Skol: - Não vai dar, eu estou preso aqui.

Imagem: Rapaz enquanto fala ao telefone está na rede, com duas mulheres. Locução em off: - Skol 360 ${ }^{\circ}$, a cerveja com bebabilidade! Aliás churrascabilidade! Se for dirigir não beba! 


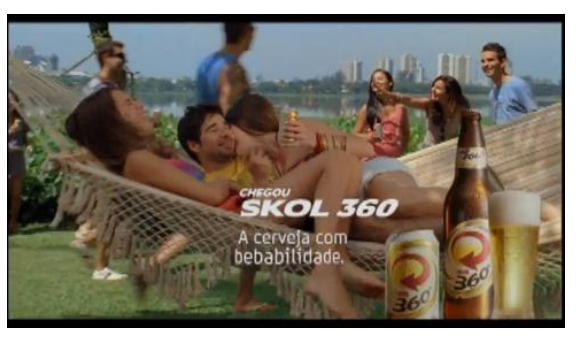

Figura 11 - Skol Churrascabilidade 2011

Esse vídeo faz uma comparação entre a cerveja quadrada e a Skol. Com a cerveja quadrada, os rapazes ficam presos porque estão empapuçados, enquanto os que tomam Skol ficam presos ocupados com as mulheres, no caso, com duas mulheres na rede.

\section{Skol Palestra Pé no feriado 2012:}

Imagem: Enquanto assistem a uma palestra, rapazes jogam pebolim com os pés.

Locução em off: - Tá com pé no feriado? Agora é só botar a mão em uma Skol de graça. No feriado você compra 11 latinhas e ganha uma grátis. Confira as condições no site.

Imagem: Corta o cenário da palestra e mostra os rapazes jogando baralho com os pés. Uma mulher se aproxima.

Mulher: - Nossa, quanto você calça?

Rapaz: - 44.

Mulher: - Ah não parece!

Imagem: Todos começa a rir.

Locução em off: - Feriado é com Skol! Se for dirigir não beba!

A referência sobre o pé ressaltada no vídeo parece fazer uma menção ao tamanho do falo. São os pés masculinos que empreendem todas as ações do vídeo. O homem, ao ser perguntado, pela mulher, quanto calçava, responde 44, a mulher discorda da reposta e o ridiculariza, sendo o diálogo motivo de risada pelos demais homens presentes na mesa.

\section{Skol Roupa Nova 2012:}

Trilha Sonora: Música Linda, da banda Roupa Nova.

Imagem: Aparecem várias situações em relação à lata de cerveja Skol. Ela na praia, na cachoeira, num balanço com flores e cabelos compridos e loiros, com outra lata de cerveja numa banheira, com várias roupas femininas (de maiô, de 
Havaianas, de animadora de torcida, de blusa branca transparente com dois peitos). Ao final um homem segura a lata nova de cerveja.

Locução em off: A Skol tá de roupa nova. Se for dirigir não beba.

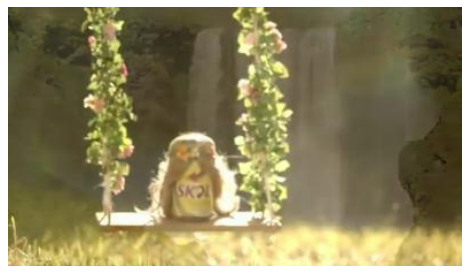

Figura 12 - Skol Roupa Nova 2012

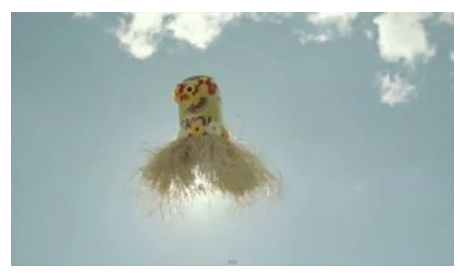

Figura 13 - Skol Roupa Nova 2012

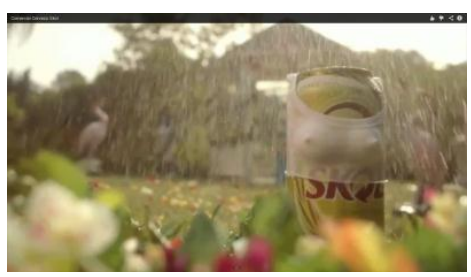

Figura 14 - Skol Roupa Nova 2012

No vídeo constrói-se uma clara associação entre a lata de cerveja e o corpo feminino, inclusive tem uma parte em que a lata cai em um monte de pétalas de rosas vermelhas e também tem uma cena em que a garrafa de cerveja se desnuda da roupa em que estava enrolada e a lata de cerveja também. Logo após, vem a cena das pétalas de rosas, tudo no clima romântico da música de Roupa Nova e, ao final da narrativa, um homem segura a lata de cerveja na mão, numa clara mensagem de que a roupa nova da Skol é destinada aos homens.

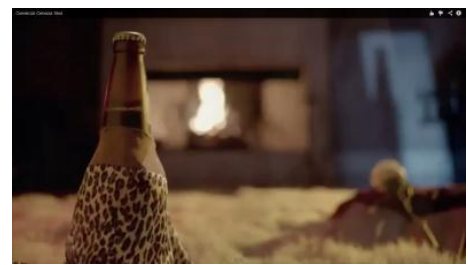

Figura 15 - Skol Roupa Nova 2012 


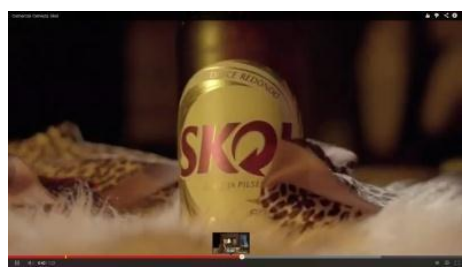

Figura 16 - Skol Roupa Nova 2012

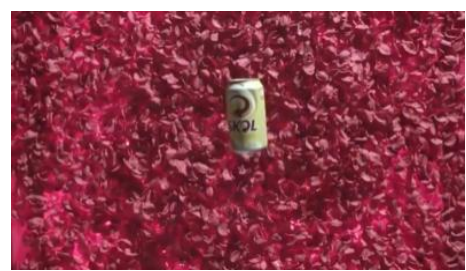

Figura 17 - Skol Roupa Nova 2012

\section{Skol Perguntas 2012:}

Imagem: A primeira cena do vídeo ocorre num pit stop, numa espécie de depósito de bebidas, mas da Skol e com um vendedor atrás do balcão.

Vendedor: - Quer economizar? Troque no supermercado suas garrafas de Skol litrão vazias por cheias e pague só pelo líquido. Alguém tem alguma dúvida?

Imagem: Passa uma mulher no cabeleireiro.

Mulher: - E eu que sou viúva como é que eu faço?

Vendedor: - Boa pergunta, senhora viúva. A senhora traz suas garrafas vazias e troca pelas cheias.

Imagem: Passa para um senhor penteando uma peruca.

Senhor: - E no caso de eu ser cagueca?

Vendedor: - Boa pergunta, senhor cagueca, o senhor traz as garrafas vazias e troca pelas cheias.

Imagem: Abre numa mulher loira, com vestido dourado, deitada num divã e se olhando em um espelho.

Loira: - E eu que sou rica e gostosa

Vendedor: - Boa pergunta, senhora rica e gostosa, a senhora traz suas garrafas vazias e fala comigo, fala comigo que eu vou estar aqui pessoalmente para atender.

Locução em off: Skol litrão, o jeito mais redondo de economizar. Se for dirigir não beba. 
O final deste vídeo traz uma distinção de tratamento entre os clientes, ao tratar a mulher rica e gostosa de forma diferenciada. O personagem explica à viúva e ao senhor careca que, ao trazerem as garrafas vazias, eles voltarão com elas cheias, enquanto para a mulher rica e gostosa ele recomenda trazer suas garrafas vazias e falar com ele pessoalmente. A personagem rica era protagonizada por Val Marchiori, socialite que acabara de participar do realite show Mulheres Ricas, portanto, existe uma dose de humor na peça. No entanto, ao mesmo tempo, há a presença de tratamento diferenciado para categorias diferentes de pessoas.

\section{Skol Despedida 2012:}

Trilha Sonora:, I Don't want to miss a thing, da banda Aerosmith.

Imagem: O soldado abraça sua esposa ao se despedir para ir à guerra. A câmera foca no documento do Convocado. O soldado segue com os outros, em direção a um jipe. Ao dar as costas para a esposa, o soldado tira a farda e coloca o colar de carnaval, enquanto o outro coloca um nariz de palhaço. Eles seguem em direção ao carnaval. Trilha Sonora: A música entra num ritmo de samba.

Locução em off: A operação Skol Folia convoca você para a maior operação da sua vida. Os vencedores passam 5 dias invadindo os melhores carnavais do Brasil, com os amigos, de jipe, de jatinho ou de navio. Participe! Operação Skol Folia. Aliste-se! Imagem: Na casa onde ocorreu a despedida, soldados batem à porta e a esposa abre. Esposa: - Morreu?

Imagem: Soldados balançam a cabeça em sinal levantando os dedos num ritmo de dança.

Caracteres: Se for dirigir não beba!

O vídeo é uma paródia do filme Armageddon, no entanto, vemos que a linguagem se dirige aos homens, pois foram eles que saíram para o carnaval. Além disso, o discurso é todo direcionado ao gênero masculino. Apesar do caráter bem humorado, o vídeo não deixa de diferenciar espaços para homens e mulheres no carnaval, espaço público e privado. Além disso, ao traçar um paralelo com a guerra, "os vencedores passam cinco dias invadindo os melhores carnavais do Brasil, com os amigos de jipe, de jatinho ou de navio.", acaba focando no alvo masculino. A mulher, no final da narrativa, mostra-se apreensiva. Ela está fora do carnaval e do clima de festa 
porque pensa que o homem morreu, mas os generais avisam que ele estava no carnaval. A inovação aqui é a utilização da paródia para falar do carnaval e também num clima de guerra, só que, nesta, da alegria, no entanto, a linguagem continua voltada para os homens.

\section{Skol Love Story 2012:}

Locução em off: No começo, o namoro é lindo.

Imagem: Entra uma mulher com Skol na mão e entrega para o namorado.

Mulher: - Uma Skolzinha pro meu momô.

Homem: Ow Didi, esfregando os narizes.

Locução em off: Mas com o tempo a relação esfria.

Imagem: Passa então a mulher abrindo a porta e recebendo pizzas. E um grupo de amigos do namorado, sentado no sofá, tomando Skol.

Homem: - Ow Didi, traz uma rodada de Skol pro pessoal aí!

Mulher: - Ah eu tô ocupada, vai buscar!

Imagem: Os amigos então começam a rir.

Locução em off: Um dia, inexplicavelmente, elas se rebelam.

Imagem: Didi está na cozinha, cortando cebola, e o namorado está no banheiro. Ele abre a porta.

Homem: - Diocrécia manda uma Skol pro momô!

Imagem: Mulher se irrita. Passa a imagem de um depósito da Skol que se movimenta pela casa, o Skooler .

Locução em off: Para devolver a paz e o amor como no primeiro dia dos namorados, a Skol traz pra você a promoção Skooler de controle remoto. Quem ama acessa o site e concorre. Se for dirigir não beba.

As situações abordadas neste vídeo mostram um pouco as tarefas domésticas desempenhadas pela mulher e a solução deste problema proposta pela Skol, com Skooler de controle remoto. No entanto, o narrador diz que inexplicavelmente elas se rebelam, mas mostra as situações em que ela tem que servir ou é solicitada a isso, mesmo estando ocupada. Mais uma vez a linguagem é direcionada ao público masculino, já que a solução proposta pela Skol resolve a situação para este homem que solicita a mulher para tudo, mas apenas pede e não age. Trata-se de uma estratégia interessante de 
inovação tecnológica utilizada pela Skol, que abordou, de forma original o Dia dos Namorados. No entanto, colocou a mulher em situação de rebeldia porque se recusou a continuar servindo o namorado. A solução apresentada, então, para diminuir o conflito, foi substituir as gentilezas da namorada pelo Skooler, mas, o restante permanece do mesmo modo. Um outro ponto a ser destacado é quem bebe a cerveja nesta peça publicitária é apenas, o namorado, logo, o Dia dos Namorados o beneficiará duplamente com o Skooler e com a falta de conflito com a namorada.

\section{Skol Gerúndio 2012:}

Imagem: Em cenário de churrasco no jardim, um rapaz conversa com uma garota de biquíni, quando chega o namorado dela e dá uma tapa nas orelhas do rapaz. Depois um churrasqueiro coloca um pedaço de carne para o cachorro lamber e serve a carne para um homem. Outro churrasqueiro serve pão de alho. Um rapaz pega uma latinha de cerveja no isopor e, ao se abaixar, outros amigos chegam e sobem o rapaz pela cueca. Aparece então um notebook com uma atendente de telemarketing usando blusa decotada e passam várias imagens do serviço SAC Churrasqueiro $360^{\circ}$. Em seguida, um rapaz serve as chuletas.

Locução em off: Pro senhor que vai estar azarando as gatinhas, vai estar levando pescotapas dos namorados das gatinhas, vai estar sacaneando os convidados malas, vai estar entupindo os convidados de pão de alho ou vai estar cuecando os amigos, o seu churrasco vai estar recebendo uma soluçã,o senhor, chegou o serviço de atendimento ao Churrasqueiro Skol $360^{\circ}$, o seu churrasco tem jeito, senhor.

Imagem: Churrasqueiro serve carne para outro homem.

Churrasqueiro: - No momento, todas as nossas chuletas estão ocupadas, o tempo de espera é de 4 minutos.

Locução em off: Skol $360^{\circ}$, feita para o churrasco. Se for dirigir não beba.

O vídeo parece ser dirigido exclusivamente para os churrasqueiros. As mulheres estão presentes, mas não empreendem nenhuma ação, exceto a atendente do telemarketing que aparece com decote apresentando o serviço Sac Churrasqueiro $360^{\circ}$. Os outros momentos em que as mulheres aparecem são quando o homem fala com a mulher e leva pescotapa do namorado dela, ou quando ela circula pelo churrasco. Vemos também a preocupação dos personagens masculinos em sacanear uns 
aos outros quando entopem eles de pão de alho, quando serve carne lambida pelo cachorro ou quando levantam a cueca do outro. No restante do enredo é uma narrativa empreendida pelos homens e para os homens.

\section{Skol Treino 2013:}

Imagem: Helicópteros no céu.

Trilha sonora: Som de helicópteros se aproximando, sob uma trilha sonora tensa. Imagem: Câmera se desloca para o solo e foca no comandante.

Comandante: - Tira o pé do chão.

Imagem: É exibido um cenário de guerra.

Trilha sonora: A trilha muda para um ritmo de samba.

Imagem: Soldados correm, gritando e carregando a bandeira da Skol. Num aparente treino militar, soldados pulam corda, caem na lama com um isopor de cerveja e ensaiam uma marcha parecida com uma dança.

Trilha sonora: A trilha sonora muda novamente para trilha de guerra, misturada com um samba.

Imagem: Outros soldados fazem marinheiro com isopor de cerveja nas costas ou, fazem agachamentos dançando.

Comandante: - Vai até o chão!

Imagem: Mais soldados atravessam o rio, com grades de cerveja na cabeça. Outros batem palmas acima da cabeça, enquanto o comandante joga confetes de carnaval.

Comandante: - Mais animação! Pula!.

Imagem: Aparecem soldados beijando sacos de boxeador com desenhos de mulheres e homens.

Comandante: - Beija, Beija!

Imagem: Os soldados beijam os sacos onde as mulheres estão desenhadas. Aparece outro soldado de capacete camuflado, dentro de um lamaçal. Surge outro soldado agarrado com 3 cervejas long neck e o comandante, com megafone.

Comandante: - Pede água?

Soldado: - Não Senhor!

Imagem: Soldado mergulha no ofuror. Soldados passam embaixo de um arame farpado, com latinhas de cerveja na mão. Um soldado mexe numa radiola e cessa 
a música. Os soldados param, agacham-se e, num sinal do comandante, correm ao ataque, gritando. Um dos soldados tropeça em armadilha e cai, mas não derrama o copo de cerveja que estava segurando. Trilha sonora: Entra uma nova trilha alegre.

Locução em off: Começou a operação Skol Folia. Esse ano você pode ser um general dos melhores carnavais do Brasil. Entre no site e arrisque-se na promoção.

Imagem: Alguns soldados jogam lata de cerveja para os colegas e outros soldados beijam manequins na boca (no treino) e ficam dançando, com o dedo indicador pra cima, sob o olhar do general. Enquanto soldados treinam agarrando-se com manequins, passa uma soldado mulher e bate com um chicote na mão do soldado que escorreu a mão pelo bumbum da manequim. Soldados dançam dando pulos, enquanto um deles dá um salto mortal.

Trilha sonora: A trilha sonora muda para suspense.

Imagem: Entra em cena um soldado com roupas e equipamentos antibombas. Com alicate na mão, ele tenta tirar um sutiã da manequim, que acaba explodindo. Locução em off e caracteres: Se for dirigir, não beba.

Nesta narrativa vemos os homens em treino para o carnaval, de forma bem humorada. A figura da mulher aparece em dois momentos ou como ícone em forma de manequim ou desenho, ou como uma personagem soldado que repreende os soldados que descem a mão pelo bumbum das manequins. Ao final da narrativa, a manequim é explodida quando o soldado tenta retirar seu sutiã, parecendo fazer referência às críticas, vindas da sociedade, sobre a forma como a mulher é apresentada pela publicidade de cerveja. Além disso, vemos a presença de um personagem masculino que faz de tudo para o carnaval e que treina pela demonstração da resistência e da força.

\section{El Clipe Reduendo 2013:}

Imagem: Um grupo de 4 amigos encontra-se em aventura durante a subida da Serra do Cavalo, no México, apesar de avisados sobre lenda que dizia da maldição de Santa Helena de La Sierra. Aparece 3 mariachs cantando, com roupas tradicionais mexicanas, e a santidade pedia uma oferenda para subir o morro. O caminhão pegou fogo e explodiu, mas surgiu um freezer de Skol no 
meio do deserto.

\section{Trilha Sonora:}

"MARIACHI UNIVERSITÁRIO".

UNA AVENTURA DE PAREJAS MUNDO AFUERA UM MOTORHOME QUE DESBRAVA LAS ESTRADAS

Y LAS BELEZAS SE TORNAVAM BONS RECUERDOS

LAS CHICAS SIEMPRE SE QUEDAVAM ENCANTADAS

MAS UNA NOCHE ESCUCHARAM UNA LENDA

DE LA MONTANHA MÁS INCREIBLE DE LA TIERRA

ERA TÃO BELA QUE PEDIA UMA OFERENDA

LA MALDICION DE SANTA HELENA DE LA SIERRA

LA VIDA MANDA QUADRADO

USTED DEVUELVE REDUENDO

ÉS UN CUENTO REAL CANTADO (refrão 2x)

DEL TIPO QUE SÓ SE ACREDITA VIENDO

Y SE PARTIRAM PARA EL MORRO DO CAVALLO SIN SE IMPORTAR CON LA HISTÓRIA DEL LOCAL A SANTA HELENA NO LLEVARAM SU REGALLO Y DESPETARAM LOS ESPÍRITOS DEL MAL

TODO IA BIEN HASTA QUE EL FRENO SE ROMPIÓ

EL MOTORHOME SE DESPENCAVA SIN PERDÓN DESESPERADO UN DE LOS CHICOS SE JUGÓ MAS AL FINAL FUE UNA GRANDE EXPLOSIÓN

LA VIDA MANDA QUADRADO USTED DEVUELVE REDUENDO ÉS UN CUENTO REAL CANTADO (refrão 2x) DEL TIPO QUE SÓ SE ACREDITA VIENDO

MAS NUESTROS CHICOS ERAN MUCHO SANGUE BOM Y SANTA HELENA DECIDIÓ SE DESCULPAR AL CIEL MANDOU CERVEZAS BUENAS DI MONTÓN UN GRAN MILAGRE PRA VIAJE MELHORAR

MIRANDO EL FREEZER ERAN SÓ FELICIDAD

LA SAGA SE TORNÓ HISTORIA A SER CONTADA DIFÍCIL CRER, MAS JURO TODO ÉS VERDAD CHICOS, BURRICOS Y MUCHA SKOL GELADA

LA VIDA MANDA QUADRADO

USTED DEVUELVE REDUENDO

ÉS UN CUENTO REAL CANTADO

SE TIENE SKOL TE DIGO NO PROBLEMA 
LA VIDA MANDA QUADRADO

USTED DEVUELVE REDUENDO

ÉS UN CUENTO REAL CANTADO

DEL TIPO QUE SÓ SE ACREDITA VIENDO

ÉS UN CUENTO REAL CANTADO

SE TIENE SKOL TE DIGO NO PROBLEMA

Locução em off: Skol, a vida manda quadrado e você devolve redondo.

As referências a gênero que conseguimos ver nesse videoclipe estão no fato de a Santa Helena de La Sierra ser uma entidade feminina e vingativa, e de os narradores serem três homens mexicanos. A trilha sonora diz que as chicas ficam encantadas. Existe um conflito entra a natureza e o homem. Além disso, o fato de serem 2 amigos e 2 amigas remetem a divisão perfeita dos casais, no modelo heterossexual.

\section{Skol Baleia 2013:}

Imagem: Cinco jovens em um barco, no mar, sendo duas mulheres e 3 homens. Aparece uma mulher de biquíni amarelo e uma outra que a agarra por trás. Vem uma baleia e os engole. Lá dentro da barriga da baleia, eles descobrem um freezer de Skol e um dos rapazes sorri.

Locução em off: - Skol, a vida manda quadrado, você devolve redondo. Se for dirigir não beba.

Imagem: Mostra uma boate na barriga da baleia.

Percebemos uma mudança na narrativa da Skol. Uma linguagem mais voltada para os jovens. As mulheres são as que gritam ao entrar na barriga da baleia, ao ver a caveira e o rato. Quem está à frente do grupo é um homem e é ele quem primeiro percebe a vantagem da situação.

\section{Skol Design 2013:}

Imagem: A personagem feminina chega na residência do namorado e troca a estátua dele do futebol por um vaso com flores lilás, retira a bagunça de cima da mesa da sala e coloca uma estátua onde está escrito love, troca o timão de navio que estava pendurado na parede por um espelho. O namorado chega em casa, 
acompanhado pelos amigos, e não gosta.

Trilha sonora: De suspense.

Locução em off: Pra não perder o respeito dos amigos, chegou Skol Design, garrafa de alumínio que viram artigos de decoração.

Na campanha da marca Skol Design, o personagem masculino é convidado a assumir uma tarefa "feminina", que é a decoração de sua casa com garrafas de cerveja. Apesar disso, continua a contraposição entre o masculino e o feminino, valorando o masculino num nível acima do feminino; ao construir uma relação de oposição entre os símbolos colocados por ela. Também percebemos que a namorada se vinga do namorado em sua ausência, que parece ser motivada pela farra com os amigos.

\section{Skol Profissa 2013:}

Imagem: A narrativa mostra jovens que, enquanto andam de skate, seguram grades de Skol, um rapaz que derrama álcool e sal para gelar melhor a cerveja e, uns rapazes numa sala. Um deles está sentado no sofá, levanta a almofada e tem um isopor de cerveja Skol e, um cachorro que pega a garrafa de Skol na geladeira e traz até um dos rapazes. No corredor, um outro rapaz enche o elevador de grades de Skol, outro jovem pula na cesta de basquete para abrir a Skol e, outro afina a guitarra com a garrafa de cerveja. Na piscina, uma mulher abre duas cervejas Skol com os olhos e deixa as tampas em seus olhos. Passam cenas de bar, com alguns rapazes abrindo e tomando Skol, e uma jovem encostada na parede, levantando uma das mãos que segura a cerveja Skol. Muda de cena e um jovem corre em um campo e joga uma garrafa de cerveja para um casal que está no barco, no meio de um rio. Após isso mostra cena de uma mulher descendo de um escorrego e caindo na piscina. Ao final, foco em 5 garrafas de cerveja e um homem abre uma delas com o triscar de um dos dedos.

Trilha Sonora: Entregadores são bem-vindos, químicos também, acolhemos marceneiros, adestradores vem, podem vir ascensoristas, esportistas, guitarristas, aceitam-se oculistas, amadores não insistam, não nos levem a mal, mas essa Skol é pra profissional.

Locução em off: Skol profissa é retornável, é pra profissional. Se for dirigir não beba. 
Essa campanha apresenta a garrafa $300 \mathrm{ml}$ da marca de uma forma descontraída. A linguagem se dirige aos profissionais da cerveja, mostrando algumas situações em que os profissas se reúnem para tomar cerveja, no entanto, a maioria dos profissas são homens, apenas a oculista é aceita como profissa.

\subsection{Proposta de interpretação dos vídeos}

A partir da visualização dos vídeos da Skol no portal do youtube e após a conferência dos títulos das campanhas a que pertenciam e do referido ano de veiculação deles na televisão, demos início à seleção dos filmes publicitários que iríamos analisar. Para a identificação dos vídeos, utilizamos as informações disponíveis no site da agência de publicidade F/Nazca, que atende a Skol desde 1994. Em princípio, havíamos definido previamente que um período de 10 anos seria interessante para observarmos o movimento na forma de abordagem das relações de gênero nas peças da Skol, mas ao procurar e ver vários vídeos, chegamos ao período de 17 anos. Observamos estes vídeos veementemente, descrevemos os mesmos, considerando cenários, trilhas sonoras, contextos em que as situações de gênero se desenrolaram e a linguagem utilizada.

Analisamos um a um e percebemos fatores em comum e sinais de inovação em alguns momentos. Utilizamos a Análise de Conteúdo (AC) e nosso referencial teórico de gênero, criatividade e estudos culturais para mapear nosso caminho de reflexão sobre as peças publicitárias. Neste período de análise da linguagem audiovisual, encontramos 37 vídeos e chegamos, a priori, a quatro categorias: mulher como argumento de sedução da cerveja, seja como recompensa para quem consome a cerveja, seja simplesmente pela beleza associada ao produto ou ao consumidor. Masculinidade Hegemônica, pois as peças publicitárias são direcionadas aos homens e apresentam situações de exercício de um tipo de masculinidade; ausência de conflito nas relações de gênero, categoria mais relacionada à mudança na estratégia publicitária decorrente do foco no público jovem; associação icônica entre mulher $e$ cerveja, que se refere à forma de apresentar as mulheres e à relação delas com a cerveja, neste caso, como ícones. Isso, em princípio, parece ser uma estratégia para driblar as críticas de associação entre mulher e cerveja tão criticada pela sociedade e fiscalizada pelo Conar. 
É importante dizer que as peças publicitárias foram enquadradas em alguma dessas categorias devido à predominância de determinados aspectos, mas algumas peças também apresentam características de outras categorias. Também é importante lembrar que essas categorias são prévias e serão agora confrontadas e discutidas, de acordo com os estudos de gênero e de criatividade, a partir de critérios relacionados com inovação e originalidade. Ou seja, foram observadas as mudanças relacionas à construção das relações de gênero e também as continuidades, agregando os semelhantes em categorias previamente estabelecidas e identificando novas categorias ao perceber certas rupturas e novidades na abordagem dos gêneros.

Dos 37 vídeos analisados, 18 relacionam a presença da mulher com a sedução ou apresentam-nas como argumento, em sua maioria loira, ou de biquíni, com a cerveja Skol. São elas: Eu quero mais, eu quero Skol (1996), Alegria do Brasil (1997), Redondezas (1998), Bunda Quadrada (1998), Praia (2000), Pequenininho (2001), D. Carminha (2001), D. Carminha 2 (2001), Mulher loira paquera homem burro (2002), Skol Ilha Quadrada x Ilha redonda (2003), Mulheristicamente (2004), Será (2005), Tubarão (2005), Musa do Verão (2006), Mulher de Amigo Meu (2007), Cartório (2008), Skol 360 Churrascabilidade (2011), Skol Perguntas (2012).

Dos 19 vídeos que restaram, 14 apresentam a questão da masculinidade hegemônica, como em: Banheiro (2000), Casamento (2004), Ah o Verão (2006), Choque em geladeira (2007), Redondo é rir da vida (2009), Churrasco (2009), Litrão e Beto Barbosa (2010), Terremoto (2011), Gerúndio (2012), Palestra Pé no feriado (2012), Despedida (2012), Love Story (2012), Skol Design (2013) e Skol Profissa (2013).

Apenas 3 vídeos analisamos como ausência de conflito nas relações de gênero, que são Skol Carnaval 2011 (mais voltadas para o público jovem), Baleia (2013) e El Clipe Reduendo (2013); e em 2 identificamos a associação icônica entre o corpo da mulher e a lata de cerveja, Skol Roupa Nova (2012) e Skol Treino (2013).

Em termos de porcentagem, 48,65\% das peças publicitárias apresentam as mulheres de forma sedutora ou como argumento; 37,84\% tratam das masculinidades; $8,11 \%$ são consideradas inovadoras porque atendem ao público jovem e apresentam ausência de conflito nas relações de gênero; e 5,4 \% apresentam a associação icônica entre a mulher e a cerveja. 
Já em relação aos cenários ou situações em que os vídeos acontecem: 8 são no bar $(19,44 \%) ; 6$, na praia $(16,67 \%) ; 6$, em casa $(16,67 \%) ; 5$, no churrasco $(13,89 \%) ; 5$ apresentam variados cenários em narrativas mais longas (13,89\%); 4 ocorrem em cenários comuns de verão $(11,11 \%)$; e 3 , em cenários relacionados com o carnaval $(8,33 \%)$.

Para visualizarmos melhor cada categoria vamos exemplificá-las.

a) Mulher como argumento de sedução da cerveja: Skol Praia 2000 é uma peça veiculada durante o verão, mostra uma mulher loira de biquíni, correndo na praia, ao encontro de um extraterrestre, num clima de paquera permeada pela Skol. Ao anoitecer, mostra a nave espacial em trepidação e o narrador diz que será o verão mais Skol do milênio. Este vídeo, na verdade, associa a ideia de que até mesmo um ET pode conquistar uma loira se estiver com a Skol na mão. A mulher não necessariamente está em posição de objeto, mas no papel que desempenha dentro da trama, percebemos que ela se torna um argumento positivo na escolha de compra da Skol. Também exemplificamos com a peça Skol Musa do verão 2005, que diz que se o cara que inventou a Skol tivesse inventado a musa do verão, ela seria clonada em série e entregue em domicílio, a cada um dos homens que tomam a Skol, associando mulher e mercadoria. Durante o vídeo, até reclamações são feitas em relação ao produto-mulher que receberam. No entanto, embora o tom seja de humor, não podemos ignorar os recursos persuasivos empregados em favor das práticas de consumo.

b) Masculinidade hegemônica: $O$ vídeo Skol Ah! o Verão 2006 mostra uma narrativa sobre situações vividas durante o verão. No entanto, a narrativa é empreendida pelas ações masculinas, inclusive o amor a uma sirigaita. Apesar de as mulheres estarem presentes na narrativa, elas cumprem um papel secundário, de estar em alguma situação de relação afetiva com os homens, para quem a linguagem está voltada, conforme indica o texto da locução: "Seja otimista rapaz, vai contar o que para o neto?"

c) Ausência das relações de gênero: Em Skol Carnaval 2011, o personagem ruivo da Skol Litrão dança Adocica, de Beto Barbosa, com outros personagens já apresentados em outras campanhas da Skol, como: uma dupla de senhoras idosas que jogavam baralho, o japonês e o quarteto de argentinos. Já em Skol Baleia 2013, aparece 
um barco no meio do mar, com um casal de mulheres que se abraçam, inclusive uma delas veste um biquíni amarelo, um casal heterossexual e um amigo sozinho. Em seguida, vem uma baleia e os engole. Dentro da barriga da baleia eles encontram um freezer de Skol e fazem a festa.

d) Associação icônica entre mulher e cerveja: em Skol Roupa Nova 2012, a lata de cerveja da Skol que está de cara nova é comparada à mulher. Apesar de não aparecer nenhuma personagem feminina corporificada, aparece a lata da Skol com várias roupas de mulheres, em várias situações, inclusive com peitos, numa relação direta entre o objeto e as mulheres.

Diante desse corpus de pesquisa observamos algumas mudanças na construção das peças, seja pelos temas e cenários que mudam, seja por pequenas inovações como a aparição de um homem como garçom, servindo na praia (Skol Tubarão, 2005). Apesar de a maioria dos tubarões serem mulheres de biquínis fio dental, a apresentação de um homem como tubarão já sugere um direcionamento diferente.

Já as relações de gênero, presentes em Skol Baleia 2013 e em Skol Clipe El Reduendo, parecem ser amenizadas pelo diálogo da peça com o público juvenil. Também há presença de negociações em peças como Skol Love Story 2012, na qual a relação entre namorados é amenizada por uma solução tecnológica: um Skooler de controle remoto. Apesar de as relações de gênero, neste caso, continuarem na dicotomia homem toma cerveja com os amigos e mulheres servem a cerveja -, a mulher se rebela e abre-se a negociação com vias para a solução, o Skooler.

Outra abordagem interessante é a de Skol Design 2013, pois a mulher se vinga: enquanto o namorado sai para a farra, ela decora a casa conforme o gosto dela. Evidentemente que ainda permanecem a diminuição do que é feminino neste filme, já que nele se diz "Não perca a moral com seus amigos", mas a reação feminina abordada e a cara de má ao final da peça, revelam uma iniciativa feminina.

Apesar dessas mudanças, percebemos também algumas continuidades nas peças publicitárias da Skol, como a linguagem voltada para os homens e as temáticas abordadas. Quando falamos da linguagem voltada para os homens, não é apenas porque o gênero gramatical está no masculino, mas porque a presença de palavras "rapaz", 
"filhos e netos", "beijamos sirigaitas" (Skol Ah, o Verão, 2006) revelam isso. As profissões aceitas como profissas, em Skol Profissa 2013, são um exemplo disso também. Outra questão é a aparição das mulheres majoritariamente ligadas aos homens ou porque estão interessadas afetivamente por eles, ou porque sugerem algum tipo de relacionamento com eles, assim como observou também Milito (2012), em sua pesquisa. Os homens que são apresentados nas peças da Skol também são, predominantemente, jovens e belos, principalmente até o ano de 2005, e estão sempre dispostos a conquistar as mulheres. Nos casos em que eles não aparecem nestas situações, eles são os palhaços da história (Skol Será 2005; Skol Litrão e Beto Barbosa, 2010). Essa margem de "saída do modelo, alto, jovem e belo" é observada somente nos casos em que o humor predomina na peça. Além disso, os homens que não representam a Skol, em sua maioria, são os gordos, mais velhos ou burros, como em Mulher loira paquera homem burro (2002) e Skol Mulheristicamente (2004).

\section{8 - Observação do Cenário}

Percebemos que os estudos que se debruçam sobre as relações de gênero na publicidade trazem contribuições fundamentais para entendermos a problemática das relações de gênero nas peças publicitárias de cerveja. No entanto, acreditamos que a realização de grupos focais, pode contribuir para a compreensão das significações dessas mensagens publicitárias junto aos receptores.

O público alvo da publicidade de cerveja Skol são homens e mulheres entre $18 \mathrm{e}$ 45 anos, das classes A, B, C e $\mathrm{D}^{23}$. Por isso, durante a realização dos grupos focais atentamos para esta questão, procurando envolver participantes de classes sociais variadas. Por se tratar de um público-alvo bastante heterogêneo, os integrantes dos grupos focais foram selecionados na perspectiva de comporem grupos homogêneos a partir da categoria de gênero - feminino e masculino - e estarem dentro da faixa etária do público-alvo, que também se interessassem a participar da pesquisa e que envolvesse pessoas de classes diferentes. Observamos e analisamos o que eles pensam sobre a publicidade de cerveja, suas significações, opiniões e leituras, e a interação que acontece durante o grupo.

\footnotetext{
23 Informação obtida em questionário enviado por e-mail ao setor de atendimento da agência F/Nazca Saatchi \& Saatchi, que atende a Skol, em 29 de novembro 2013.
} 
Dessa maneira, vamos analisar a partir dos estudos de criatividade as permanências e rupturas na linguagem publicitária observando os fatores de originalidade e inovação na construção das relações de gênero. Em seguida analisamos como esta construção é apreendida e significada pelos receptores e posteriormente vamos confrontar a opinião dos participantes dos grupos com as categorias prévias a que chegamos com a análise da linguagem dos 37 vídeos publicitários da Skol.

\subsection{Grupos Focais}

Adotamos a técnica de pesquisa do grupo focal para aprofundar algumas questões referentes à recepção das peças publicitárias de cerveja Skol veiculadas na televisão. Foram realizados 3 grupos focais na cidade de João Pessoa, dois com mulheres e um com homens. Essa divisão se deu devido à disponibilidade de participarem da pesquisa e também porque os dois primeiros grupos a serem realizados foram os compostos por mulheres, sendo um, majoritariamente, com participantes de classe média e outro de classe menos favorecida. O terceiro grupo foi feito com homens. A intenção da pesquisa era realizar igualmente o número de grupos por gênero, no entanto, surgiu a oportunidade de realizar mais um com mulheres e não quisemos dispensar. Também durante o percorrer da realização dos grupos, sentimos a necessidade de fazer um grupo misto, mas em virtude do tempo de concussão desta pesquisa, não foi possível. A cidade pessoense foi escolhida em virtude de a pesquisadora ser natural deste local. Para cada grupo atribuímos uma letra, então chamemos grupo A, B e C. O total de gravação de áudio dos grupos foi de 6 horas. Foram compilados os mesmos 37 vídeos, o que chegou a um tempo de 30 minutos, descritos aqui nesta pesquisa juntamente com uma proposta de interpretação. Durante os grupos focais esta sequência de vídeos foi exibida enquanto todas as discussões estavam sendo gravadas e todas as interações e reações que se davam durante o desenrolar dos diálogos nos grupos, anotadas.

A seleção dos participantes do grupo focal se deu de acordo com a disponibilidade e o interesse das pessoas, que foram convidadas para participar da pesquisa. Como já dissemos anteriormente, tentamos abarcar homens e mulheres entre 18 e 45 anos, de variadas classes sociais. Dessa maneira, os arranjos dos grupos se deram neste sentido de composição, respeitando a formação dos grupos específicos, de acordo 
com o gênero, mas que envolvesse pessoas de classes e profissões variadas. É importante dizer que todos os nomes envolvidos, nesta pesquisa, estão reservados ao anonimato, sendo atribuídos, aos participantes, pseudônimos.

O grupo A foi formado por mulheres, assim como o grupo B. O grupo C por homens. Para a realização do grupo A foram convidadas dez mulheres. O primeiro encontro foi realizado numa sala da Universidade Federal da Paraíba, onde foi apresentada a pesquisa e foram feitas algumas perguntas introdutórias do mesmo roteiro feito para todos os grupos focais. No entanto, para o segundo encontro não foi possível compactuar as agendas, por isso, fizemos o mesmo no salão de festa da residência de uma das participantes do grupo A, isto porque a dificuldade de fazer com que reuníssemos novamente aquele grupo de mulheres nos levou a esta solução negociada por todas as participantes. A composição do grupo A ficou dessa maneira:

\section{Grupo Focal A}

\begin{tabular}{|l|l|l|}
\hline Nome & Profissão & Idade \\
\hline Raimunda & Estudante & 26 anos \\
\hline Karina & Designer Gráfica & 41 anos \\
\hline Alice & Estudante & 24 anos \\
\hline Soraia & Jornalista & 34 anos \\
\hline Mariana & Empregada Doméstica & 38 anos \\
\hline
\end{tabular}

É importante dizer que reunir as mulheres e homens dentro do perfil que traçamos inicialmente na pesquisa, que era compor grupos por gênero masculino e feminino, mas atentando e perseguindo para que os grupos fossem formados respeitando a diversidade de idade, classe, e profissão, colocou-nos diante da dificuldade de sintonizar agendas e horários em que mulheres e homens de segmentos diferentes pudessem dispor de seu tempo para a pesquisa, apesar do imenso interesse sinalizado por ambos desde o primeiro contato.

Para o grupo A foram convidadas 10 mulheres, tendo comparecido 5 delas, as quais continuaram também na etapa de aprofundamento das questões durante o segundo encontro. As mulheres do grupo A tinham entre 24 e 41 anos, com as seguintes profissões: estudantes, empregada doméstica, jornalista, e designer gráfica. As mulheres deste grupo foram selecionadas por frequentarem bares no bairro dos Bancários, em João Pessoa, local onde circulam artistas e comunidade universitária, estarem dentro da idade 
esperada e por terem aceitado participar da pesquisa sobre publicidade. Elas não fazem parte de um grupo de amigas, mas frequentam e compartilham da ambiência do bairro dos Bancários.

O procedimento foi executado da seguinte maneira, no primeiro momento foi feita a apresentação da pesquisa, os objetivos dela e algumas perguntas introdutórias sobre o perfil de cada participante e questões gerais sobre publicidade e a influência dela. Na apresentação da pesquisa explicamos que estávamos realizando uma pesquisa de pósgraduação sobre publicidade e que a realização dos grupos focais tinha como objetivo verificar as opiniões dos participantes sobre a publicidade de cerveja Skol, o que eles achavam sobre os vídeos e que para isso iam ser exibidos vídeos veiculados na televisão aberta do período de 1996 até 2013. Também explicamos que a opinião de todos era igualmente importante e que eles se sentissem a vontade para fazer comentários, perguntas ou permanecer em silêncio, caso não quisessem opinar. Já em relação às questões gerais sobre publicidade, conversamos sobre quais peças publicitárias ou campanhas, de cerveja ou não, elas lembravam, se haviam sido influenciadas por elas, e se elas achavam que a publicidade influenciava as pessoas para a compra ou nas atitudes. No segundo momento, foi colocado um vídeo com as 37 peças publicitárias que analisamos anteriormente, visando fomentar as discussões em grupo, a respeito das peças. Este mesmo procedimento foi realizado nos outros 2 grupos, o B e o C.

Devido à dificuldade de reunirmos homens e mulheres com atribuições variadas em um espaço próprio de pesquisa, decidimos partir para a inserção na realidade deles e delas e realizar os grupos onde fosse possível encontrar abertura para a realização da pesquisa durante o próprio desenrolar da vida cotidiana. No entanto, combinamos anteriormente com os componentes dos grupos que nas ocasiões do nosso encontro precisaríamos de um espaço reservado para a conversa e exibição dos vídeos, assim como no procedimento adotado no grupo A.

Por isso, no grupo B, fomos até uma feijoada realizada por um grupo de mulheres e lá conversamos com elas e exibimos a seleção de vídeos, o que gerou uma discussão interessante. O grupo B foi formado por 5 mulheres entre 28 e 45 anos, das seguintes profissões: donas de casas, doceira, auxiliar de biblioteca e cabeleireira. Elas fazem parte de um grupo de amigas que sempre se reúnem nos finais de semana, no bairro Castelo Branco, em João Pessoa, para se confraternizarem. Durante o procedimento de pesquisa na qual nos encontrávamos, observamos esse grupo de mulheres coeso e 
repetidamente se encontrando em frente da casa da participante Sávia. Ao perceber essa movimentação rotineira nos aproximamos do grupo e convidamo-las a participar do grupo focal. A composição do grupo B foi assim:

\section{Grupo Focal B}

\begin{tabular}{|l|l|l|}
\hline Nome & Profissão & Idade \\
\hline Sofia & Auxiliar de Biblioteca & 45 anos \\
\hline Sávia & Doceira/ Enfermeira & 37 anos \\
\hline Mazé & Dona de casa & 40 anos \\
\hline Malú & Dona de casa & 43 anos \\
\hline Jânia & Cabeleireira & 28 anos \\
\hline
\end{tabular}

No grupo C, tomamos a mesma direção: fizemo-nos presentes durante um churrasco realizado por um grupo de 5 homens, durante o final de semana. Os homens tinham entre 21 e 40 anos e eram: técnico de iluminação, agente comunitário de saúde, auxiliar administrativo, estudante, auxiliar de portaria. Esse grupo de homens foi selecionado porque tinham o hábito de se reunir durante todos os dias de domingo para tomar cerveja e escutar músicas em uma rua localizada no bairro de Castelo Branco I, em João Pessoa. Circulávamos com frequência por este bairro, e isto nos despertou o interesse de entender o hábito deste grupo em se reunir frequentemente para beber cerveja, bebida preferida deles. Nele, seguimos o mesmo procedimento aplicado no grupo B, de conversamos sobre o perfil de cada participante e exibir os vídeos, seguidos pelas discussões.

\section{Grupo Focal C}

\begin{tabular}{|l|l|l|}
\hline Nome & Profissão & Idade \\
\hline João & Técnico de iluminação & 21 anos \\
\hline Mário & $\begin{array}{l}\text { Agente Comunitário de } \\
\text { Saúde (ACS) }\end{array}$ & 25 anos \\
\hline Ariano & Auxiliar Administrativo & 30 anos \\
\hline José & Auxiliar de Portaria & 40 anos \\
\hline Carlos & Estudantes & 27 anos \\
\hline
\end{tabular}

Em cada grupo percebemos que as discussões variaram em alguns poucos pontos 
e tinham muito em comum. Diante desta constatação, seguimos as orientações de análise dos grupos ficais feitas por Gatti (2012):

Os pesquisadores procuram verificar, quanto ao tema e quanto aos tópicos abordados, agrupamentos de opiniões, comparando e confrontando posições, extraindo significados das falas ou de outras expressões registradas, analisando a vinculação desses agrupamentos com as variáveis contempladas na composição do grupo. Destacam-se nessa análise tanto as opiniões que foram majoritárias como as que ficaram em minoria, sendo relevante a exploração destas. A composição e o confronto dos achados com as teorizações ou hipóteses dos pesquisadores devem ser, então, cuidadosamente elaborados. (GATTI, 2012, p. 47)

Durante as discussões em grupos, pudemos perceber o riso em muitos momentos da exibição dos vídeos e, em outros momentos, um incômodo e alguns comentários. Essas observações foram registradas e analisadas posteriormente.

A forma como mulheres e homens receberam as peças publicitárias de cerveja foi diferente. As mulheres, sempre muito falantes e inquietas e os homens, muito concentrados, rindo bastante. No grupo B, as mulheres ficaram tão inquietas que mal começou a exibição dos filmes já dispararam: "Eu sempre quis fazer essa pergunta: por que só mostra mulher gostosa e quase nua nestas propagandas?" (SOFIA). Durante a realização do grupo focal $\mathrm{C}$, os homens permaneceram num silêncio, quebrado apenas pelas risadas.

Durante a análise das peças publicitárias, na qual apresentamos anteriormente uma proposta de interpretação, chegamos às seguintes categorias: 1- mulher como argumento de sedução, 2- masculinidade hegemônica, 3- Ausência das relações de gênero e 4- Associação icônica entre mulher e cerveja.

Já na realização dos grupos focais, as discussões ficaram em torno das Peças Publicitárias: Cenários, Machismo e Felicidade, tratando sobre linguagem, discurso e cenários das peças publicitárias; Personagens: Construção e Identificação, abordando a construção dos personagens masculino e feminino e se há identificação dos receptores com eles; Influência da publicidade e formas de consumo de cerveja, verificando se a publicidade impacta o consumo de cerveja junto aos receptores e as formas de consumila.

Assim, descreveremos a seguir as discussões realizadas nos grupos por temas:

\subsection{Peças Publicitárias - Cenários, Machismo e Felicidade}

Intitulamos esta seção desta maneira para tratarmos dos assuntos que mais 
chamaram a atenção dos componentes dos grupos focais relacionados à linguagem, ao discurso e aos cenários das peças publicitárias.

Procuramos entender o que mais havia chamado a atenção dos participantes dos grupos nos vídeos, as peças mais marcantes, a significação das mensagens e cenários.

Vamos iniciar nossa descrição ainda durante a exibição dos vídeos, porque algumas participantes do grupo A se manifestaram com comentários e reações que merecem ser descritas aqui. Enquanto passava o filme Mulher loira paquera homem burro, Soraia comentou: “A macharia todinha entendeu, né?!", frisando o fato de apenas o homem que estava sendo convidado para tomar uma cerveja Skol com a loira não ter entendido, mas o restante dos homens presentes na praia terem, não somente entendido, como passado a ajudar a mulher a explicar o convite. Já a outra participante do grupo A, Mariana, achou o mesmo vídeo "repetido, tem que ter paciência!". Após assistir à peça Skol Casamento, em que o noivo pergunta se a noiva será gostosa para sempre, Soraia volta a comentar: "Não lembrava dessa não".

Já no grupo B, as mulheres também fizeram comentários e perguntas ainda durante a exibição dos vídeos. Elas ficaram incomodadas e foram logo se posicionando, como é o caso de Sofia, ao dizer: "Peraí, essas mulheres não tomam cerveja não. Quem toma cerveja é a gente! Eu achava que ia passar os homens gostosos também pra gente olhar." Outra participante do grupo B, Sávia, perguntou: "Eu sempre quis fazer essa pergunta, por que só mostra mulher gostosa e quase nua, nestas propagandas?”. A exibição dos vídeos continuou e as mulheres do grupo B riram bastante enquanto passava a peça Skol Carnaval 2011, onde aparece o cantor Beto Barbosa cantando e algumas pessoas dançando a lambada Adocica.

Houve uma diferença no comportamento dos participantes do grupo $\mathrm{C}$, que permaneceram em silêncio durante a exibição, no entanto, demonstrando uma interação por meio de muitas risadas durante todo o processo. $\mathrm{O}$ fato de sermos mulheres e estarmos em contato com um grupo masculino pode ter interferido na recepção, no entanto, não percebemos nenhuma sinalização neste sentido. Parecia que o grupo havia esquecido que estávamos lá e havia interação entre eles todo o tempo.

Portanto, percebemos elementos comportamentais e também questões que levaram ao riso ou ao incômodo ainda durante a exibição dos vídeos.

Após a exibição dos vídeos, uma questão inicial foi feita pela participante Soraia, do grupo A, que começou a conversa perguntando se existia alguma propaganda de 
cerveja feita para mulheres. Karina, então relatou: "Eu lembro de uma propaganda para mulheres em que elas estão no sofá, tirando onda dos homens que estão passando. Mas é só inversão de papéis".

Neste sentido, as mulheres do grupo A frisaram a necessidade de que a inversão de papéis não resolve a questão problemática, já que, na opinião delas, trocar os homens pelas mulheres continuaria a existir a mesma conduta desigual e machista.

O que mais chamou atenção nas peças para Karina, do grupo A, foi a ideia de felicidade, de vender um ideal de beleza, felicidade e juventude, essa mesmo ideia foi ratificada por Alice: "É a ideia de felicidade e incorporação ao grupo, quando você bebe aquilo é só coisas legais, felicidade e sucesso.”.

Já para Sávia, do grupo B, o que mais chamou atenção foi o uso do corpo da mulher para vender a cerveja.

Pra mim o que mais chamou atenção para comprar a cerveja foi o corpo feminino porque a gente não viu um homem sem camisa não viu nada de exposição masculina. Todas as propagandas tem mulher de biquíni, mulher se expondo, é a exposição do corpo feminino. (SÁVIA)

Os integrantes do grupo $\mathrm{C}$ disseram ser as mulheres o que mais lhes chamaram a atenção. Eles responderam ao mesmo tempo, riram e João explicou: “A propaganda de cerveja vem através delas, antes da cerveja vem logo a mulher.”

Sendo assim, o que mais sobressaltou a atenção nas peças, para o grupo A, foi o ideal de felicidade, para o B, o uso do corpo feminino e para o $\mathrm{C}$, as mulheres.

A insatisfação das mulheres com sua representação nos vídeos foi assunto trazido pelos grupos A e B, configurado como machismo. Karina justifica: “É socialmente aceitável o machismo presente nas peças, pois isso não impede, nem homens, nem mulheres de beber Skol.” Já Sávia, do grupo B, acha que o modo como as mulheres são apresentadas é "para vender porque se não fosse assim eu acho que a Skol não venderia. A Antarctica também faz a mesma coisa". E Malú, também do grupo B, completa "a Devassa também coloca lá a mulher só de biquíni e o corpo dela". Para Mário, participante do grupo focal $\mathrm{C}$, a combinação mulher, cerveja e futebol é a mistura perfeita que atrai os homens.

Uma questão comum para todos os grupos foi o posicionamento de que nas peças publicitárias da Skol não houve grandes mudanças. "Olhe essas propagandas que vocês mostraram foi de 1996 a 2013, de lá para cá mudou alguma coisa? Quase nada! Mudou 
os personagens, mas a brincadeira é a mesma.” (ARIANO). Para os participantes dos 3 grupos essa manutenção é sustentada pelo público que gosta do que ver e consome.

As mulheres do grupo A explicaram que este discurso da publicidade, apesar de machista, existe porque vivemos numa sociedade que sustenta e aceita com naturalidade o problema. "As mulheres não deixam de consumir por ser machista, até porque isto é reflexo da sociedade que vivemos e é muito naturalizado pelas pessoas".

Raimunda, também componente do A, opinou que, de forma geral, as peças publicitárias da Skol são voltadas para o público jovem, masculino e que adota um padrão machista onde as personagens femininas brancas, magras e de cabelo liso têm predominância, no entanto:

"As morenas, as negras, os homossexuais não deixam de consumir Skol porque eles não aparecem, tanto que se vocês for conferir nos últimos anos se não mudou muita coisa é porque tá tendo uma boa resposta e tá mantendo aquele padrão."

Para Alice, do grupo A, a apelação sexual com as mulheres foi se atenuando ao longo do tempo.

Porque na década de 90 eram várias, todas faziam essa apelação. Como na década de 90 tinha É o Tchan, banheira do Gugu, a gata molhada tava dentro desse contexto. Agora acabou, essas coisas já não existem mais, aí a coisa foi atenuando, mas ainda continua com essa apelação da mulher.

No entanto, para Karina a exploração de sensualidade nas propagandas de cerveja não se justifica por este contexto, porque: "Na minha época era Gretchen e ela era muito apelativa, se você pensar, ela usava biquíni e o É o Tchan usava shortinho! "(KARINA)

Os participantes do grupo $\mathrm{C}$ trazem um posicionamento interessante ao dizer que as mulheres não são objetos sexuais, e sim "gostosas", apesar de concordarem com o fato de que as peças são "feitas para os homens com certeza. Churrasco, pagode, mulher e cerveja que aparecem nos vídeos, quem é que não gosta?" (JOÃO).

Quanto aos vídeos mais lembrados ou mais citados pelas participantes do grupo A, Raimunda disse ter chamado sua atenção Skol Bunda Quadrada, quando o homem está vendo tudo quadrado e, ao tomar cerveja, fica tudo redondo. A Skol Musa do Verão foi lembrada por Soraia pelo apelo sexual presente e a Skol Banheiro também, por causa do bullying à virilidade masculina. No entanto, houve ponderações acerca de uma mudança na forma de promover a Skol, demonstrada na fala de Alice. 
Tem uma propaganda que eu achei a mais diferente de todas as outras, El Clipe Reduendo, eu achei diferente, assim ainda era direcionada para o publico jovem, mas era outro tipo de público, um público viajante. Eu achei diferente pela viagem, sair de um lugar.

Mas o restante do grupo discordou dizendo que permanece o padrão masculino branco, jovem e as mulheres presentes na peça continuam como companheiras deles. $\mathrm{O}$ vídeo Skol Baleia e Skol Terremoto também foram citados como exemplos de que a Skol resolve todos os problemas. "Passa a imagem de que não tem problema, a baleia engoliu todo mundo, mas quando veio a Skol ficou a maior festa. $\mathrm{O}$ terremoto engoliu todos, mas nada importa só a Skol” (MARIANA). Para Aline, neste caso, é “a fuga da realidade, é como se tudo passasse a outro patamar de vida onde tudo fosse perfeito". E para Raimunda, a dos Amigos foi bem interessante, a que os amigos no churrasco levam cerveja quadrada e querem beber cerveja redonda, porque olhando para a construção da propaganda, eles misturam realidade com ficção:

Porque isso acontece, as pessoas riem, acham engraçado, mistura a realidade com a ficção que é para ficar uma coisa mais amarrada e mais verdadeira e quem vê aquilo diz: ah é, os amigos realmente levam uma e querem beber a outra.

No entanto, as integrantes do grupo A disseram que essa dos Amigos foi muito pesada porque mostra o amigo ajudando o outro a fingir que estava doente para encobrir a traição dele, parecendo ser este o papel de uma amizade. A peça Skol Folia 2013 foi citada por causa da presença de manequins e de uma mulher assumindo um papel masculino e o vídeo Skol Design foi avaliado, negativamente, ao ligar tudo o que é feminino ao que é cafona. "Eles utilizam o rosa, o love, o tom romântico, do sentimento, aí quando o casal briga, entra uma trilha de terror, tipo filme de Hitchcock". (KARINA).

O vídeo Skol Roupa Nova foi citado pelos grupos A e C. No grupo A, Soraia disse que a lata era o centro e personificava uma mulher, o que inclusive havia ficado ridículo. João, do grupo C, achou muito engraçado o Roupa Nova e disse: "É muito legal, a cerveja vai em cima do cavalo, cabelo galego e não cai”.

Já a Skol Mulher loira paquera homem burro foi citada pelos grupos B e C. "Naquela que a mulher paquera homem na praia, aquilo não acontece na vida real, dá licença!” (SOFIA) e Sávia concorda e critica: Você viu alguma mulher ali? Porque eu só vi homem! Só tem a gostosona lá e o resto tudo homem". No grupo C, João pergunta: "Qual o homem que não ia entender uma loira chamando ele para beber na praia? Nem 
um doido, não tem como, fosse comigo não tinha erro."

Portanto, a peça Mulher loira paquera homem burro parece deslocada e fora do contexto que vivem os integrantes dos grupos $\mathrm{B}$ e $\mathrm{C}$, o que causa estranhamento e ao mesmo tempo chama a atenção dos receptores.

O grupo A e B também levantou a problemática da falta de visão do mercado para perceber que as mulheres também consomem cerveja.

Já ao serem perguntados sobre o que desce redondo, o grupo A disse ser o que não dói, a vida, o prazer, a revolução ligada à descoberta da roda. Os grupos B e C responderam na mesma direção, dizendo ser, às vezes a cerveja, às vezes a mulher e às vezes os dois.

\subsection{Personagens: Construção e Identificação.}

O incômodo das mulheres em se verem consideradas meramente como apelo sexual ou objeto foi um assunto recorrente no que se refere à construção das personagens das peças publicitárias de cerveja Skol.

As componentes dos grupos A e B apresentaram de forma crítica e contundente suas opiniões acerca de como as mulheres aparecem nos vídeos. "Prontas a serem consumidas. Nessas propagandas aí, nesta seleção que vimos aqui, é a constatação da mulher vista como objeto." (SORAIA). De acordo com Karina, as mulheres estão representadas a partir de um estereótipo machista: "Loira, gostosa, burra e dentro de uma estética padrão que focaliza pro peito e pra bunda. Para se ter um ideia não tem nenhuma mulher de cabelo curto, por exemplo". No grupo C, formado por homens, de fato, a resposta dada ao serem questionados sobre o que mais chamou atenção nos vídeos e por que, foi: são as mulheres porque elas são gostosas. "A maioria delas está de biquíni, são sedutoras, elas são o marketing do negócio”, explicou Mário.

No entanto, enquanto para as mulheres é um incômodo serem tratadas meramente como um corpo a ser consumido e no papel das gostosas, para os homens esse argumento, das mulheres gostosas, as colocam em um patamar superior e louvável. "Eu acho que elas se sentem mais superiores que a gente. Elas pensam: Olha que homem besta." (MÁRIO).

Variaram as opiniões entre homens e mulheres, ao abordar se os homens gostam dos personagens masculinos criados pela publicidade de cerveja. Enquanto os homens se vêem retratados como fúteis, as mulheres do grupo A opinaram que acreditam que eles 
adoram esse papel apresentado pela publicidade, justificado segundo elas, pelo fato deles serem mostrados como os pegadores de mulheres. Eles pensam: "Estou reinando", diz Mariana. Para uma das participantes do grupo B, por exemplo, eles "Parecem uns urubus, sempre querendo pegar as mulheres." (JÂNIA). No entanto, as mulheres do grupo B acreditam que os homens não gostem de suas representações nos vídeos, já que em Mulher loira paquera homem burro, as mulheres disseram: "Aquela propaganda que a mulher convida o rapaz para tomar cerveja na praia, ele pensam: Oxe, esse é imbecil, fosse eu já estava lá. (SÁVIA). Já para um dos participantes do grupo C, João, existe o incômodo de ser retratado como superficiais nas propagandas.

Porque a mulher aparece mais, e os homens aparecem em situações de zoação, de tirar onda com o outro, de bobos, os homens sempre pagando uma prenda, coisas que a gente sabe que não acontece. A mulher não, a mulher aparece fazendo uma coisa que a gente sabe que existe. (JOÃO)

Os homens se sentiram incomodados com os papéis masculinos assumidos pelos personagens sempre pagando prendas, ou em situações vergonhosas nas peças, mas inicialmente, durante conversa, não mudariam em nada a construção das peças. "Uma coisa bem criativa que eles fazem" disse João. Ao ser perguntado se mudariam algo nas peças, João respondeu que não por que "querendo ou não tem muita coisa engraçada, divertida.".

Perguntamos ao grupo $\mathrm{C}$ como eles achavam que as mulheres se viam nos vídeos, se eles achavam que elas gostavam ou não. A maioria disse não fazer ideia ou não saber. Bem diferente da opinião dos grupos $\mathrm{A}$ e $\mathrm{B}$, que se arriscaram numa suposição dos homens vendo os filmes publicitários em questão. Quando perguntamos aos grupos A e B se os homens gostavam da forma como as mulheres apareciam nos vídeos, elas nos dois grupos disseram acreditar que os homens gostavam muito, divertiam-se e ainda que "eles se identificavam como numa espécie de espelho" (KARINA).

Fato interessante ao serem perguntadas sobre a questão da sedução das mulheres nas peças publicitárias foi escutar as mulheres do grupo A discordarem com o termo sedução e proporem o termo atraentes, pois para elas a questão da sedução pressupunha uma relação de troca, o que em suas opiniões não acontecia. Essa foi uma questão defendida por todas as componentes do grupo e que nos trouxe uma visão diferente acerca das análises do estudo empírico 1. 
A primeira resposta do grupo A foi:

Não, eu acho que elas são mais seduzidas, não tem sexualidade ativa não, elas são objetos. Porque a sedução também implica uma coisa mais ativa, não só a passividade, elas são as gostosonas, mas são sempre passivas, né? (SORAIA).

Então, outra componente do grupo propôs: "O termo então é atraente; elas são mais atraentes porque sedutoras pressupões troca e elas teriam que ter participação o processo. (ALICE).

No entanto, Karina discordou neste ponto com Alice, expondo que as mulheres eram sim sedutoras pelo ponto de vista masculino.

Eu volto para aquele estereótipo do machista ocidental, latinoamericano. Elas são sim sedutoras, no meu ponto de vista, mas elas são porque se encaixam neste estereótipo machista, ocidental, latinoamericano. Bunda, peito, cabelo liso, branca e loira. (KARINA)

Para os participantes do grupo focal B e C, as mulheres também são sedutoras porque aparecem sempre em situação de seminudez.

Eu acho que é porque elas estão seminuas assim com o intuito de vender, minha filha, porque vende mesmo. Pra vender porque, se não fosse assim, eu acho que a Skol não venderia. A Antarctica também não bota? (MAZÉ)

Já no grupo C, José disse que nas peças publicitárias “os homens aparecem bobos e as mulheres insinuosas".

Raimunda, participante do grupo A demonstrou incômodo com as personagens femininas: "Praticamente não existe fala dessa mulher, explora só o corpo dela físico, quando ela aparece, é sempre chamando atenção para o físico." (RAIMUNDA). Ou seja, "mulher é um rótulo para ganhar dinheiro." (JÂNIA), completou a outra participante.

Assim, o diálogo levou a constatação de que para os grupos formados por mulheres existe uma imposição do padrão de beleza, tanto para homens quanto para mulheres, e uma intensa exposição do corpo das mulheres.

Quanto ao padrão de beleza podemos dizer que ele foi percebido para as mulheres e para os homens, mas não chegou a ser tratado pelo grupo dos homens. "O padrão da Skol é a mulher loira, branca, magra, jovem e o homem também branco, magro e jovem. Quem não se enquadrar neste perfil bebe cerveja quadrada.” (RAIMUNDA).

Já em relação à identificação dos homens com os personagens presentes nas peças, segundo José, ela não acontece: "Não me identifico com eles, eu só me identifico 
com o cara que toma cerveja quadrada e vira baiacú, eu tô do mesmo jeito", pode explicar, por exemplo, a inadequação de seu próprio corpo com aos padrões masculinos apresentados nas peças. Apesar de não aparecer a questão, nitidamente, do padrão imposto também aos homens, a fala de João dá pistas da existência da percepção de um estereótipo masculino também.

No entanto, os homens, quando questionados sobre o que mudariam nas propagandas de cerveja, já que apresentaram seu incômodo em relação à atuação dos homens em situações constrangedoras, disseram: "Pra mim continua a mesma coisa que tá bom.”, explicou Ariano.

Ao insistirmos na questão se não deveria mudar nem a presença dos homens bobos, João respondeu: "Seria melhor um homem mais mala, chegando assim, tirando uma boyzinha de besta, como elas tiram a gente, seria melhor, porque a gente acha engraçado, mas ninguém gostaria de estar na pele de alguns personagens ali”. (JOÃO)

\subsection{Influência da publicidade e as formas de consumo de cerveja}

Neste item discutiremos sobre a influência da publicidade na opinião dos participantes dos grupos focais, considerando como eles vêem esta questão, se as peças publicitárias sugerem ou não um modo de se comportar, se existe verossimilhança entre as situações mostradas nos vídeos e as vivenciadas na realidade; e também sobre as formas de consumo da cerveja para homens e mulheres, ou seja, em que situações mulheres e homens fazem uso da cerveja e como é feito.

As discussões em grupo sobre as formas diferentes de consumir a cerveja levaram as mulheres do grupo A a falar da dificuldade que enfrentam para frequentar bares.

\footnotetext{
Se você se sentar numa mesa de bar sozinha, para beber, sempre vai ter um engraçadinho que vai chegar e oferecer uma bebida para você, pagar uma bebida para você. A mulher não tem o direito de sentar na mesa e beber sozinha, ela tem que estar à caça ou à disposição. $\mathrm{O}$ homem se acha no direito de sentar na mesa e querer pagar uma bebida. Isso é uma coisa que tem que mudar muito, se você chegar numa mesa de bar é muito difícil você não ser abordada. Porque os homens acham que você está sofrendo e solitária. (MARIANA)
}

E a abordagem desse assunto levantou outra questão relacionada às mulheres em bares, o fato de que, muitas vezes, os homens tratam as mulheres nestes locais, as mulheres que estão sós, ou as que estão em grupos, com violência. A participante do 
grupo A, Raimunda, relatou um episódio que ela presenciou em um bar de João Pessoa.

A gente tava sentada, aí chegaram duas umas mulheres de 40, bem arrumadas, e passaram por nós. Tinha um cara jovem, sentado na mesa, simplesmente ele se levantou, agarrou uma delas e beijou à força. A gente ficou assim indignada, aí ela se livrou e saiu. $\mathrm{O}$ cara achou que porque era uma mulher de 40 e tal, podia fazer isso, já que ele era novinho, tinha uns 27 anos, entendeu? Notoriamente foi uma agressão. (RAIMUNDA)

Para Aline, também do grupo A, este tipo de ação acontece muito comumente durante as festas de carnaval, onde o consumo de cerveja é muito incentivado. Outra questão citada foi a relação desta situação de violência com a percepção de que nas peças publicitárias da Skol não se mostra, nem a mulher mais velha, nem os homens mais velhos, consumindo cerveja, o que, neste quesito geracional, destoa, na opinião das participantes, do que acontece na vida real.

No entanto, para os grupos A e C, as formas de consumo, ou seja, as situações de consumo que aparecem nas peças estão de acordo com o que acontece no cotidiano. É o que explica João: “Acontece, tudo isso aí acontece numa festa, é uma coisa normal que a gente está acostumado a ver, como, por exemplo, uma menina sensualizando quando vai pegar uma cerveja”.

Mariana, do grupo A, concorda: "Quando você chega a um shopping, você vê as torres de cerveja, é raro alguém tomar um chope e se satisfazer. Ninguém toma uma cerveja só." (MARIANA).

Já para as componentes do grupo $\mathrm{B}$, as situações mostradas nos vídeos não mostram o comportamento do homem e da mulher que bebem cerveja, porque "só mostra o comportamento da mulher para vender a cerveja e chamar o homem a consumir, através da figura da mulher, mostra só o conceito do vamos ingerir, vamos ingerir" (MAZÉ). O integrante do grupo C, Ariano, fez uma comparação entre o que acontece na vida real e nas peças publicitárias em questão, que de certa maneira complementa a ideia defendida por Mazé.

Em bares, a maioria dos frequentadores são homens. A presença de uma mulher lá vai atrair os homens. Se tiver uma mulher servindo a cerveja num bar, isso vai atrair homens para este bar por conta da mulher. Os homens pensam: - Ah, vamos lá porque quem vai servir lá é fulana, pode ser a pior do mundo, mas é assim que funciona.

Portanto, neste quesito se a publicidade da Skol está de acordo com o que acontece na realidade, não houve consenso, e sim, a oscilação entre retratar situações que 
acontecem na vida cotidiana (Grupo C), mas de apresentar personagens distantes dos homens e das mulheres reais (Grupo A) e de alguma maneira, as integrantes B apresentam a ideia do incentivo ao consumo em grandes quantidades e associado às mulheres, o que deixa de existir nos cenários do dia-a-dia, conforme relato por Mariana, do grupo A, e Ariano, do grupo C.

As mulheres do grupo A disseram concordar com o fato de que a publicidade sugere como homens e mulheres devem se comportar.

Tanto que eles buscam uma linguagem que o público compactue: se a vida tá dura, tome uma Skol; a vida manda quadrado você devolve redondo. Então eles sempre se voltam para situações que o público se identifique e você vai a fundo. (RAIMUNDA)

No entanto, para elas a realidade das peças publicitárias é diferente da que elas mesmas vivem. "Eu não circulo neste ambiente de pessoas perfeitas, mulheres perfeitas, homens sensuais", justifica Soraia. Raimunda pondera dizendo que "as pessoas compram a ideia da publicidade inconscientemente de que vai desopilar, encontrar os amigos, então de certa maneira acabam acompanhando o que ela mostra e diz".

Um dos componentes do grupo $\mathrm{C}$ disse que os vídeos sugerem um comportamento mais interessante para as mulheres que para os homens.

Você viu alguma mulher daquela pagando uma prenda? Fazendo um negócio, pagando mico? Eu não vi, eu só vi homens, porque não fazer uma propaganda com mulheres fazendo tudo isso? No exército e tudo. (ARIANO).

Sobre a influência da publicidade para o consumo de cerveja, todos os participantes concordaram que existe uma forte influência da publicidade para o consumo da bebida, no entanto, as opiniões diferem quanto ao tipo de influência.

Uma influência em curto prazo é relatada por João: "O cara vendo uma propaganda massa de cerveja dá logo vontade de tomar uma cerveja.".

Ou em longo prazo, como o defendido por Raimunda:

Não é que eu me sinta diretamente influenciada. Mas, outro dia eu tava em casa, na hora do almoço, eu vi uma propaganda de cerveja. Apesar de achar machista, cafona, que eu não concorde, mas eu não vou negar que aguça os meus sentidos, causa uma reação ali com certeza. Sinceramente, eu acho que eu só bebo cerveja por causa da propaganda, porque, eu nem gosto muito, é só pela questão da cultura mesmo. Eu não acho cerveja boa, é tanto que, quando eu era adolescente eu dizia que era muito ruim. A primeira vez que eu tomei cerveja, eu estava na praia, com minha irmã e meu cunhado, eu estava morrendo de sede, aî 
eu falei assim peça uma água para mim, aí ela falou assim: Que água que nada menina, vamos tomar uma cerveja, eu lá vou gastar dinheiro com água!? E eu tomei, eu tava com tanta sede e o sol da praia quente, que eu tomei e disse: É bom mesmo! Matei minha sede. Então é isso, está ali na sociedade, não tem como não ser influenciada por isso. (RAIMUNDA)

Ou um tipo de influência que, não especificamente que leve a beber Skol, mas sim a associar cenários à prática de beber cervejas de forma geral.

Não me identifico a beber Skol, porque não gosto da linguagem, mas o consumo da cerveja, de forma geral, influencia sim. Por exemplo, a associação sol, praia e cerveja vem disso. (SORAIA)

Sávia, do grupo B, diz que acredita que quem é mais influenciado pelas propagandas de cerveja Skol é o público jovem que ainda não tem referências suficientes para refutar a mensagem.

Não me influencia porque eu tenho uma cabeça, mas uma pessoa mais jovem aí já influencia. Meu conceito é, se você prepara seu filho em casa, nada te influencia, porque eu comecei a trabalhar com 12 anos, então drogas, bebidas, nada me influenciou, essa era minha cabeça, eu tenho essa meta então eu vou nela. (SÁVIA)

Soraia, do grupo A, concorda com Sávia quando diz que "a publicidade influencia muito nitidamente com informação para o público mais jovem.”.

No entanto, para Karina, a publicidade tem uma influência tão grande no repertório cultural das pessoas que mesmo as mulheres fora do padrão construído pela Skol, tendem a se sentir as gostosas das propagandas:

E elas, mesmo que não estejam dentro do padrão das mulheres da Skol, elas se sentem assim, pois quando você vai no chorinho e vê uma mulher gordinha de shortinho curto de oncinha, sem dentes e o cara se aproxima, ela pode até não ser a loira da Skol, mas se sente assim como a gostosa da cerveja. (KARINA)

Os relatos pessoais de Karina revelam que a publicidade exerce sobre ela alguma influência. "Eu odeio sol, churrasco, fumaça, suor, catinga de cerveja, mas aí eu vou para um churrasco e aí eu faço assim que droga como eu vim para aqui, o que eu tô fazendo aqui? Influência da propaganda." (KARINA).

Esses posicionamentos nos sugerem que, apesar de visões diferentes, todos os participantes concordam que a publicidade influencia quem assiste, às vezes, de forma direta e, às vezes, não. Mas esses posicionamentos também revelam a dificuldade de reconhecer de que forma ela atua individualmente e coletivamente. 
Quanto ao consumo, Raimunda diz que a própria linguagem da Skol sugere formas de consumo e um jeito de consumir, quando o slogan diz:

Se a vida tá dura, bebe uma Skol. As pessoas compram essa ideia inconscientemente, que vai lá para desopilar e encontrar os amigos, quando você vai, de uma certa maneira você vai acompanhando aquilo. (RAIMUNDA).

Mariana concorda com Raimunda, ambas do grupo A, ao observar que:

[...] muitas pessoas preferem beber em lugares públicos do que em casa, porque diz que o sabor da cerveja em casa não é o mesmo do da rua, logicamente que ao sair você encontra um grupo de amigos, se confraternizar, igualzinho ao que acontece na publicidade (MARIANA)

Já com relação às formas de consumo passadas na publicidade, segundo os grupos, elas estão de acordo com um discurso de felicidade, pois:

Ninguém bebe para afogar as mágoas na propaganda, porque na realidade muita gente bebe para afogar as mágoas e cadê né? Todo mundo super feliz, super sucesso, bem realizada. Só se você beber a cerveja errada é que o problema vem. (SORAIA)

Isso pode mostrar jeitos diferentes de lidar com o consumo de bebidas, pois se para uns o uso delas serve para anestesiar a dor, para outros é uma forma de sociabilizarse.

Outro assunto apontado foi o fato de a publicidade de cerveja ter uma linguagem muito mais voltada para o público masculino, o que, segundo Raimunda, não faz com que o consumo diminua por que:

É assim se tem uma campanha $\mathrm{X}$ e essa campanha nada alterou as vendas, eles vão entender isso como tá ótimo, vamos continuar, porque se as mulheres se posicionassem e não consumissem mais e houvesse queda nas vendas, eles teriam que mudar a linguagem e a forma de fazer. Porque esse machismo é socialmente aceitável, agora coloque um casal homossexual se beijando, que as vendas iam cair, e a Skol quebrava, porque não é tão aceitável como o machismo. A coisa só vai refletir quando a sociedade mudar porque aí incomodaria a ela ver esses estereótipos e desigualdades (RAIMUNDA).

Mas Karina discorda, dizendo que: "Eu acho que é para o público jovem, mas é para a mulher sim, porque é a mulher que quer aquele tipo de marido, que quer aquele tipo de situação." A outra integrante do grupo concorda: “também é voltado para mulher, porque tá ali aquele modelo patriarcal, aquele príncipe, mas quem disse que o príncipe encantando é encantado? É aquele cara machista que vai estar ali dominando". 
(RAIMUNDA). Os integrantes do grupo C também acreditam que as peças da Skol são direcionada para os homens.

Dessa maneira, segundo as opiniões vindas dos grupos, podemos dizer que a publicidade da Skol é, majoritariamente, voltada para o público masculino e para as mulheres que se identificam com a forma como este modelo de ser masculino é construído.

\subsection{Discussão grupos focais em comparação à proposta de interpretação dos vídeos:}

A realização dos grupos focais foi de fundamental importância para esta pesquisa, pois a partir deles foi possível observar as reações, significações e um pouco mais do mundo que circula em torno do consumo e da publicidade de cerveja.

Percebemos que as mulheres participantes dos grupos focais A e B se sentiram incomodadas com as peças publicitárias, que de modo geral, segundo as opiniões delas, são de cunho machista. Para elas, a mulher está posta como uma forma de chamar a atenção dos homens, objeto sexual, sedutoras.

Já os homens se sentiram incomodados com a forma fútil como são representados nos personagens, no entanto, ao nos referirmos ao que precisaria mudar, eles levantaram a necessidade de que estes personagens fossem mais "malas", mais malandros e que fizessem as mulheres de idiotas, igualmente na posição em que eles são colocados na publicidade, de acordo com a opinião geral deles.

Acreditamos que, apesar do incômodo, a solução encontrada por eles em nada altera a posição de fúteis a que eles são submetidos, havendo, portanto, apenas a proposta da inversão dos papéis e se aproximando cada vez mais do fortalecimento do "homem pegador" a que as mulheres se referiam.

Já em relação às mulheres, a proposta delas, é que acabem com esta exposição do corpo feminino, até porque esse corpo ideal não representa seus próprios corpos e atende um padrão de beleza irreal. É o caso de Sofia, do grupo B, que declarou discordar que as personagens femininas da publicidade eram gostosas, porque ela era gostosa e as outras participantes do grupo também, mas, não estavam ali representadas. "Eu sim tomo cerveja, essas mulheres aí não", declarou Sofia.

Em nenhum momento os homens perceberam ou acharam problemática a forma como as mulheres eram apresentadas nos vídeos, ao contrário das mulheres que foram 
capazes de se arriscar, achando que os homens não iriam gostar da forma como foram representados por causa da peça Mulher Loira paquera homem burro e também identificaram a forma estereotipada como homens e mulheres eram retratados. O que parece, é ser naturalizado para eles, o fato de as mulheres serem o mais importante nas peças publicitárias e a reafirmação de que eles gostam disso e que essa é a combinação perfeita pra vender cerveja. Assim, podemos dizer, na direção do que Saffioti frisou: “os processos socioculturais de discriminação contra a mulher e outras categorias sociais constitui o caminho [...] para legitimar a "superioridade" dos homens, assim como a dos brancos, a de heterossexuais, a dos ricos." (SAFFIOTI, 1987, p.11). As outras categorias sociais podem ficar a cargo da forma como os feios, gordos, os velhos aparecem nos vídeos, sempre na posição do ruim, da cerveja quadrada sem qualidade, a exemplo da enfermeira gorda que substitui a D. Carminha, que está de férias no vídeo D. Carminha 2.

Durante a análise dos vídeos que realizamos antes dos grupos focais, chegamos as categorias: mulher como argumento de sedução da cerveja, masculinidade hegemônica, ausência nas relações de gênero e associação icônica entre mulheres e cerveja. Essas categorias, chamamos de categorias preliminares, justamente porque elas seriam confrontadas com as discussões dos grupos para verificar suas impressões, identificações, significações, influências, comportamentos e relevâncias. Aqui nesta seção é isso que estamos nos propondo a fazer agora. Como resultado das discussões nos grupos focais, chegamos aos temas: Peças publicitárias: cenários, machismo e felicidade, Personagens: construção e identificação e Influência da publicidade de formas de consumo. Agora vamos confrontar as categorias prévias da análise dos 37 vídeos com os temas debatidos nos grupos.

Nesse confronto podemos verificar, por exemplo, a discordância das mulheres do grupo focal A com a utilização do termo sedução, empregado anteriormente na categoria Mulher como argumento de sedução da cerveja, e a proposição do termo atraente. Isto porque, para as mulheres deste grupo, elas não são sedutoras, mas sim atraentes. E apesar das mulheres do grupo B terem concordado com o fato de as mulheres nas peças serem sedutoras, elas argumentaram que quase sempre as mulheres estão seminuas, porque, se assim não fosse, os homens não se interessariam, o que caracteriza o conceito atraente como mais adequado. Os homens do grupo $\mathrm{C}$ também opinaram neste sentido de que a “propaganda da cerveja vem através das mulheres" (JOÃO), configurando o conceito de atraente. 
Apesar da linguagem de sedução ser uma estratégia utilizada pela publicidade para mobilizar os receptores, as mulheres, de fato, nas peças publicitárias da Skol fazem parte da linguagem de sedução, mas estão como objeto de atração para que a sedução aconteça. Sendo assim, a categoria que tínhamos elegido anteriormente, nomeando-a de Mulher como argumento de sedução da cerveja passa a ser Mulher como objeto de atração.

Agora vamos confrontar a segunda categoria da análise preliminar dos vídeos que é Masculinidade hegemônica. Esta categoria foi assim definida por causa do conceito de Masculinidade Hegemônica, utilizado por Connel (1995), que distinguiu a hegemônica de outras masculinidades, especialmente das subordinadas, sendo adotada por uma minoria de homens que a adotam e que ditam as normas da forma mais honrada de ser homem e exige que todos os homens se posicionem em relação a ela, ao mesmo tempo em que submete e legitima a subordinação das mulheres aos homens. (CONNEL, MESSERSCHMIDT, 2013).

Homens que receberam os benefícios do patriarcado sem adotar uma versão forte da dominação masculina podem ser vistos como aqueles que adotaram uma cumplicidade masculina. Foi em relação a esse grupo, e com a complacência dentre as mulheres heterossexuais, que o conceito de hegemonia foi mais eficaz. A hegemonia não significava violência, apesar de poder ser sustentada pela força; significava ascendência alcançada através da cultura, das instituições e da persuasão. (CONNEL, MESSERSCHMIDT, 2013)

Neste sentido, as discussões em grupo legitimaram a existência desses elementos nas peças publicitárias, de um modo único de ser homem, de um modelo, de uma forma de agir, de pensar. Como exemplo dessas discussões, podemos citar a referência que as mulheres do grupo B fizeram aos personagens masculino como os pegadores, assim como as mulheres do grupo A que falaram na peça Skol Redondo é rir da vida 2009, trazendo elementos dessa narrativa masculina única e dominante em que os homens traem e as mulheres são cúmplices. "A propaganda que me marcou e ficou na minha cabeça foi aquela dos amigos, que são amigos mesmo, que tomam cerveja, foi muito forte, um encobre o outro, aquela foi muito pesada, foi uma das que ficou na minha cabeça.", declarou Alice, e Mariana complementou: "O cara tá com outra, finge que tá doente com termômetro na boca, chegou a mulher, a amante sai do banheiro o amigo a agarra, encobrindo a traição do amigo."

Já Soraia, também do grupo A, cita a peça Skol Banheiro 2000 como uma 
referência à virilidade masculina em questão, quando, ao urinar um dos homens do banheiro geme e fica com vergonha, numa espécie de recado segundo o qual não tomar a Skol, o gemido será de sofrimento, de constrangimento. Para os participantes do grupo C, os homens apresentados nas peças são bobos, no entanto, eles são considerados bobos porque pagam prendas e porque essencialmente "nem um doido" (João) não entenderia a mulher loira chamando o homem para tomar uma Skol na praia. Além disso, a proposta deles de sanar este problema de aparecer como bobos é ser "um homem mais mala, chegando e tirando uma boyzinha de besta, como elas tiram a gente, seria melhor (João). Isto caracteriza o incômodo com o fato exclusivo de serem apresentados como engraçados ou em posições de constrangimento, mas não com o fato de serem o macho alfa eternamente interessados em mulheres, solicitando assim "um homem mais mala". Este fato foi demonstrado pelo modo como outros integrantes do grupo focal $\mathrm{C}$ responderam ao que deveria mudar nos personagens masculinos das peças de cerveja da Skol, dizendo para continuar do jeito como está. Portanto, a categoria Masculinidade Hegemônica ao ser cruzada com as discussões nos grupos focais foi condizente com o direcionamento para a mesma significação que fizemos ao analisar as peças.

Entre as peças mais citadas pelos participantes dos grupos estão Mulher loira paquera homem burro, como uma referência de que uma situação daquelas jamais existiria e foi citada pelos 3 grupos . Os vídeos Bunda quadrada e D. Carminha 2 foram citados pelos grupos A e B, por causa da forte relação mulher e cerveja. Já as peças El Clipe Reduendo e Baleia foram citadas porque abordavam situações inusitadas. Skol Roupa Nova foi citada pelos grupos A e C, por causa da associação da lata de cerveja com a mulher e Skol Carnaval 2011 foi citada no grupo B por ser engraçada.

Já em relação à categoria Ausência das relações de gênero, no confronto com as opiniões e interações que aconteceram durante os grupos focais, podemos falar não em ausência, mas sim num silêncio dessas peças com enfoque no que tange à construção das relações de gênero. As peças elencadas na análise prévia do corpus dos vídeos da Skol na categoria prévia Ausência das relações de gênero, eram: Carnaval 211, Baleia 2013, El Clipe Reduendo. O último foi considerado por Alice, do grupo focal A, como diferente de todos vistos anteriormente, já que nele não aparecia a mulher nua de biquíni. No entanto, esta argumentação de Alice gerou um diálogo de discordância com as outras participantes do grupo A, que disseram ser as mulheres presentes nesta peça todas companheiras dos caras, além disso, a própria música dos Mariachs diz que "as meninas 
ficam encantadas". Ou seja, mudou a forma de caracterizar a personagem feminina, ela não está de biquíni, mas continua a estar presente nos vídeos para complementar a presença do homem, sempre caracterizadas como companheiras dos homens, presentes em função da existência de um personagem masculino. Já no vídeo Baleia 2013, o comentário veio de Mariana, do grupo A, que afirmou não existir problemas neste vídeo, somente a felicidade materializada na presença da Skol. "Passa a imagem de que não tem problema, a baleia engoliu todo mundo, o desespero, mas quando veio a Skol, ficou numa festa." (MARIANA).

No entanto, neste vídeo são as mulheres quem gritam e, é o homem que percebe, primeiro, a situação de vantagem que favorece o fato de terem sido engolidos por uma baleia. Portanto, o que acontece não é bem uma ausência, mas sim um silêncio das relações de conflito de gênero, comumente caracterizadas nas outras peças analisadas. Silêncio este que está associado com as exigências do Conar, em 2008, de mudar a forma como a mulher era apresentada nas peças publicitárias de cerveja, orientando para se evitar tratar as modelos com apelo sensual ou como objeto sexual. Essa mudança também pode ser explicada pelo diálogo mais direto com o público mais jovem, como os próprios participantes dos grupos focais A e B perceberam que o público mais jovem é o mais influenciado pela publicidade de cerveja.

Também havíamos identificado uma outra categoria prévia que dialoga neste mesmo sentido de atender as orientações do Conar e também de sanar as inúmeras críticas advindas da sociedade, que é a Associação icônica entre mulher e cerveja. As duas peças que incluímos nesta categoria foram comentadas pelos grupos focais, uma delas a Skol Roupa Nova, foi comentada por 2 grupos focais como: engraçada (Grupo C), ridícula (Grupo A). Já na Skol Folia 2013, as participantes do grupo B identificaram que até nos sacos de pancada o desenho é de uma mulher nua e as do grupo A atentaram para a existência de uma personagem feminina que assumia um papel masculino, uma soldado, mas que, mesmo assim, não deixava de ocupar um papel machista na narrativa.

No que se refere à identificação dos participantes dos grupos focais com a seleção de vídeos de cerveja Skol exibidos, podemos dizer que as mulheres dos grupos não se identificam com a construção das personagens, mas acreditam que ela gera identificação nas mulheres que desejam ter aquele tipo de homem tal qual os personagens masculinos das peças. Elas também acreditam que nem as mulheres, nem outros segmentos vão deixar de beber a cerveja Skol por causa da forma desigual como são tratadas nas 
narrativas publicitárias. Já os homens se identificam muito com os personagens masculinos apresentados, apesar de se incomodarem com o fato de estarem, muitas vezes, ocupando o papel de fúteis. No entanto, durante a recepção podemos perceber como eles interagiam com as narrativas, rindo, achando as peças interessantes e se divertindo, havendo inclusive bastante diferença para as mulheres que mostravam indignação ainda durante a exibição dos vídeos, fato que ocorreu nos grupos A e B, enquanto no grupo $\mathrm{C}$ houve silêncio, riso e comentários como: que legal, que massa, engraçado esse viu, etc. 


\section{CONSIDERAÇÕES FINAIS}

Existem questões relacionadas à esta problemática das relações de gênero na publicidade que transbordam a ficção, do mesmo modo que a realidade demonstra mudanças que a ficção das narrativas publicitárias não consegue acompanhar, ou não tem esse papel. Como explicar o descompasso do avanço das mulheres no mercado de consumo de cerveja e a não correspondência desse mercado em investir em publicidade para esta fatia da população? Estamos falando da alienação do mercado para estas mulheres, ou seria porque a publicidade não as influencia, ou ainda porque elas estão satisfeitas com o modo como elas estão sendo apresentadas nas peças publicitárias?

De acordo com a opinião dos participantes dos grupos focais que realizamos não se trata nem de uma questão nem de outra, já que eles se sentem influenciados pela publicidade e que, nem homens nem mulheres estão totalmente satisfeitos com a forma como são apresentados nelas.

Para responder as inquietações desta pesquisa é preciso uma abordagem multiperspectívica (Kellner, 2001), já que é preciso verificar como os meios de produção, nesse caso, operacionalizados pela publicidade e materializados pelo consumo, juntamente com a linguagem da publicidade, por meio do exercício da criatividade, totalmente calcada na cultura e em meio à realidade sociocultural das relações de gênero em nossa sociedade, consegue responder se a publicidade de cerveja da Skol dos últimos 17 anos, de 1996 a 2013, inova na abordagem das relações de gênero.

Portanto, existem níveis de análises que precisam ser levados em consideração. Um deles é o próprio funcionamento do produto da comunicação, no caso da publicidade, onde podemos verificar como ela opera na construção das relações de gênero. $\mathrm{O}$ outro é a análise textual de conteúdo e crítica da própria linguagem das peças publicitárias, analisando se houve ou não inovação. O terceiro nível são os do estudo de recepção, aqui caracterizado pelos 3 grupos focais realizados, onde a estrutura social vem à tona evidenciando a questão do gênero com mais complexidade. Um nível não se descola do outro, mas cada um é capaz de explicar por ângulos diferentes a mesma problemática.

Nas análises de conteúdo que fizemos a partir dos 37 vídeos publicitários da Skol podemos dizer que houve sim inovações na construção dos personagens masculino e feminino, pois as mulheres que antes apareciam nitidamente de biquíni amarelo e roupas 
mínimas, passaram a ser as mulheres "descoladas" que saem e podem ir aos bares beber, com ou sem os homens por perto. Já os personagens masculinos foram deixando os cenários da praia e seguindo para o churrasco, para o interior da casa e, embora na aparência continuem extremamente jovens, foram deixando o corpo atlético da praia de lado. Houve também inovação na forma de construir as personagens femininas após as modificações do Conar, em 2008, por exemplo, ao utilizar ícones como a lata de cerveja e manequins para apresentar a mulher.

No entanto, a grande questão é que a abordagem das relações de gênero, construídas por estas narrativas, mudou pouco. Não há uma inovação, socialmente percebida e aceita, como pode ser constatado pelo resultado das análises dos participantes dos grupos focais. Evidentemente, que a dimensão de alcance de nossa pesquisa é restrita, localizando-se a grupos específicos e por isso não há como generalizar os resultados obtidos, mas eles indicam um posicionamento neste sentido: "mudou nada" (Ariano, Grupo C), "falta de visão do mercado para perceberem as mulheres" (Soraia, Grupo A), "as propagandas são exclusivamente para o público masculino, só visa o corpo da mulher" (Sofia, grupo B).

Sendo assim, não podemos falar que as mudanças foram perceptíveis, ao menos não para os participantes dos grupos, apesar de termos percebido na análise preliminar dos vídeos, algumas mudanças nas quais elencamos ser possíveis inovações como: a construção da personagem feminina que deixa o biquíni de lado e do homem malhado que passa a ser um corpo cada vez mais recém-saído da puberdade. No entanto, essa nova forma de construção dos personagens não foi suficiente para inovar na abordagem das relações de gênero, nem na função que estes personagens exercem dentro da própria narrativa, como o papel do homem dominante que conduz os processos e o desejo intrínseco da narrativa, enquanto a mulher é conduzida e colocada na função de complementar o homem nos cenários e para chamar a atenção dele para o produto. De alguma maneira ela continua em função dele, que é o personagem principal juntamente com a cerveja. Ela é agregada ao mundo da cerveja, que nas peças publicitárias, em questão, é um mundo predominantemente masculino.

Ainda em relação à criatividade, além do fator inovação, podemos observar como a atividade publicitária utiliza bem os artifícios desta atividade humana para criar peças com o mesmo tema, utilizando-se de uma linguagem original e ao mesmo tempo adaptada ao público-alvo a que se dirige. No entanto, por ser todo o seu processo 
produtivo imbuído de elementos culturais, tanto no que diz respeito ao indivíduo que cria, quanto a todo o processo criativo delimitado pela aceitação do público, a construção das relações de gênero não foge a esse funcionamento. Não queremos dizer com isso que não existe espaço para a criatividade, pois se assim fosse, a publicidade não encontraria tantas estratégias para inovar e ter originalidade, inclusive utilizando inovações como as já citadas aqui anteriormente. Ela se modifica, se atualiza e segue construindo a sua linguagem de sedução, todavia, tanto ela reflete a cultura, quanto é construída por ela. Assim os elementos culturais estão presentes no processo produtivo e criativo, sendo a publicidade sobrecarregada de códigos culturais. Por isso, acreditamos que, para haver inovação na construção das relações de gênero na publicidade de cerveja Skol, faz-se necessário que os códigos culturais, partilhados na sociedade, mudem a ponto de forçar sua reflexão na publicidade. No entanto, outro fator opera neste processo, o fator econômico. Csikszentmihalyi (2006) contribui, neste sentido, ao afirmar que a criatividade é um sistema social que faz julgamentos sobre os produtos dos indivíduos. Portanto, se as vendas da marca Skol continuam a subir, assim como seu valor de mercado, enquanto empresa, ela não está sendo forçada a inovar na construção das relações de gênero na publicidade. Até porque é preciso haver uma tensão entre a continuidade da abordagem (a tradição) e a ruptura para que a inovação aconteça. No entanto, a cultura como o caldo que permeia tudo isso, juntamente com os fatores econômicos, podem explicar melhor esse fenômeno de continuidade, pois são os homens que dominam o processo econômico e o mercado capitalista e, portanto, os meios de produção e reprodução do status quo, o que ajuda a manter os valores culturais sedimentados na perspectiva de dominação das mulheres pelos homens.

Também não podemos esquecer que beber cerveja é também uma questão de tempo, é preciso poder beber, ter tempo para isso. Acreditamos que as triplas intrínsecas e extrínsecas, intensivas e extensivas jornadas de trabalho a que as mulheres estão submetidas impactam em formas de consumo de cerveja diferentes do mundo masculino e, portanto, se elas têm menos tempo para beber e se sobra tempo para os homens fazer isso, por que o mercado apostaria em um público-alvo como as mulheres? Mesmo que elas hoje em dia possam beber e frequentar bares, antes lugares proibidos, elas o fazem com tempo limitado. A jornada de trabalho das mulheres, somadas às horas nos espaços públicos e no trabalho doméstico e de cuidados, traduzem essa falta de tempo. De acordo com dados do Instituto de Pesquisa Econômica Aplicada, divulgados em 2012, as 
mulheres brasileiras gastam, em média, 26,6 horas semanais em afazeres domésticos, enquanto os homens dedicam apenas 10,5 horas. Em 2009, $90 \%$ das mulheres brasileiras com 16 anos ou mais de idade afirmaram realizar afazeres domésticos, comparados a $50 \%$ dos homens. Apesar da jornada média de trabalho na ocupação principal dos homens ser cerca de sete horas maior que das mulheres, a carga global de trabalho para as mulheres é maior: 57 horas por semana, sendo 53 para os homens, somando-se as duas jornadas, do trabalho remunerado para o mercado e do trabalho não-remunerado de reprodução, o que demonstra a limitação de tempo por parte das mulheres e o menor poder aquisitivo delas, já que trabalham mais no trabalho não remunerado e menos horas no remunerado.

Além disso, é preciso reconhecer, assim como Lauretis (1994) já trouxe a questão, que a publicidade funciona como tecnologia de gênero, reforçando o status quo e reproduzindo o poder dos homens sobre as mulheres para manter o domínio e os privilégios daquilo que foi e é a primeira relação de poder já relatada na história da humanidade, o domínio de um gênero pelo outro.

A partir disso podemos pensar em outras questões acerca do sistema capitalista que tenta manter tudo como sempre foi, mesmo havendo mudanças sociais, ou seja, pensar como a publicidade funciona e como ela opera as questões de gênero?

As mulheres são bastante utilizadas para vender cerveja, movimentam e atraem os homens para o consumo, no entanto, são apagadas na linguagem e no discurso das peças publicitárias de cerveja Skol. Neste sentido, Saffioti, em sua tese A mulher na sociedade de classes (1969 [2013]), já afirmava que existe incongruência na ideia de um projeto de sociedade em que as mulheres sejam incluídas no desenvolvimento capitalista na sua integridade, porque este desenvolvimento é baseado na apropriação privada dos meios de produção. Assim o capitalismo pode até estimular e permitir mudanças, todavia isso não significava a integração social feminina. No caso da publicidade de cerveja, isso parece ser um fator constatado, pois, as mulheres estão presentes, são apresentadas como personagens, cumprem um papel importante nas narrativas, cada vez mais se incluem no mercado produtivo, entram na população economicamente ativa mundial e brasileira, mas não são integradas na linguagem a que se direciona o público-alvo. Por outro lado:

[...] se observarmos o relatório da Organização Internacional do Trabalho, de 2008, constataremos que o número de mulheres que trabalham aumentou e muito: quase 200 milhões ao longo do último 
decênio, atingindo 1,2 bilhão, em 2007, contra 1,8 bilhão de homens. Todavia, a análise deste processo requer a superação de um enfoque meramente quantitativo. $\mathrm{O}$ aumento da participação feminina no chamado mercado de trabalho não se deu igualmente em todos os setores. Em geral, cresceu para as atividades mais precárias dentro do sistema capitalista. (GONÇALVES, 2013, p.24)

Portanto, quando levamos em consideração o aumento das mulheres no mercado de trabalho, devemos verificar que isso não significa aumento no poder econômico, já que elas cresceram entre a população economicamente ativa, mas continuam em situação de desigualdade econômica e social.

Assim, a questão de baixo poder econômico das mulheres pode ser mais um fator responsável pelo não direcionamento da linguagem das peças publicitárias da Skol para o público feminino.

Com isso queremos refletir que dentro da perspectiva do sistema capitalista que objetiva lucros, a mulher não está inserida completamente nesta lógica, mesmo sendo uma potencial consumidora, no entanto, na nossa opinião essa inclusão integral das mulheres no sistema capitalista também não resolveria o problema, já que a bebida vicia, está ligada a acidentes de trânsito e inserir as mulheres como plenas consumidoras e o público-alvo da publicidade só aumentaria o número de alcoolistas. O que queremos refletir é como a publicidade de cerveja opera estruturando o sistema capitalista e patriarcal, mantendo o lucro da empresa e o poder masculino, ou seja, não interessa integrar as mulheres integralmente no mercado, mas sim parcialmente, de modo que o poder hegemônico dos homens continue, tanto sobre os corpos das mulheres quanto sobre a propriedade dos meios de produção. Sendo assim, a publicidade de cerveja da Skol opera o mundo feminino totalmente a serviço dos homens e fazem assim porque podem fazer, tem poder e estrutura para agir dessa maneira.

A Skol que nasce com a proposta de inovar e acaba mesmo inovando quando aposta no público completamente jovem, diferentemente da Antarctica e da Brahma, concorrentes fortes. A Skol já lidera o mercado de vendas, mas não conseguiu superar a metonímia uma cerveja - uma mulher, nem o discurso completamente galgado numa masculinidade hegemônica em que os homens são os caçadores, os comandantes, os que percebem tudo primeiro, os que resolvem tudo e até os fúteis da história, mas são eles que hegemonizam. Isso seria o que Nolasco (1997) chama de homem de verdade e que Connel (1995) conceitua como masculinidade hegemônica, criada em "um sistema social que qualifica um dos sexos por meio da desqualificação do outro.” (NOLASCO, 1997, p. 
26).

Portanto, quem bebe Skol, bebe este estilo de vida dos personagens masculinos, o estilo redondo de ser, construído sob a ótica de um olhar masculino hegemônico, ou seja, um jeito de ser homem, de ser mulher e de se relacionar.

Evidentemente que as relações de gênero na realidade também são marcadamente desiguais, assim como Soraia, participante do grupo focal A, explica: "Se a publicidade se mantém assim é porque ela é um reflexo da sociedade que a gente tem". No entanto, esse vem sendo o habeas corpus da publicidade: é o reflexo da sociedade e o públicoalvo gosta. Isso pode explicar o fato de a construção das relações de gênero na publicidade se manter sem grandes mudanças, uma relação intrinsecamente marcada pelo domínio masculino, e extrinsecamente marcada pelo domínio dos meios de produção, em sua maioria por homens, e consequentemente dos agentes criadores da publicidade. Todavia, isso não explica, sob o ponto de vista comercial e capitalista o fato de as mulheres não serem incorporadas pela linguagem destas peças publicitárias como latentes consumidoras segundo o II Levantamento Nacional de Álcool e Drogas (2012), mesmo que com o tempo limitado, mas um alvo em potencial e crescente.

Dessa maneira, a publicidade de cerveja Skol parece renovar continuamente o símbolo da masculinidade e da configuração das relações de gênero baseados em valores intrínsecos dos mitos, que relacionam a bebida alcóolica a algum poder de domínio e disposição do mundo para determinada categoria de gente, neste caso, dos homens hegemonicamente aceitos como os modelos de homens de verdade que preconizam o funcionamento da sociedade.

Sendo assim o mundo da cerveja se apresenta como um espaço reservado para a fala masculina, para a ótica masculina, um assunto de homens para homens, independentemente da construção de personagens estereotipados (PINEDA, 2008; FLAUSINO, 2012), estratégia recorrente na publicidade. o que está em jogo é a construção de um protocolo de como os cenários de felicidade, diversão e desopilação presentes na publicidade de cerveja Skol devem tratar homens e mulheres e de quais funções cada um tem nesses ambientes.

Cabe considerar também a questão da autorregulamentação publicitária, coordenada pelo Conselho Nacional de Autorregulamentação Publicitária (Conar), que é uma problemática que não podemos deixar de falar, já que são os representantes das próprias agências de publicidade quem compõem este Conselho, o que por si só já se 
caracteriza como uma atuação contraditória, a de se autofiscalizar. A ausência, portanto, de regulamentação da publicidade de cerveja e de regulação deste setor no Brasil, provoca diversos constrangimentos, no entanto, recentemente um passo importante foi dado quanto à regulamentação da publicidade de bebidas. A Justiça alterou o horário em que a publicidade de bebidas pode ser veiculada em emissoras de rádio e televisão. Após três ações civis públicas ajuizadas pelo Ministério Público Federal (MPF), o Tribunal Regional Federal alterou a Lei 9.294/96 e restringiu a veiculação de publicidade de bebidas com teor alcóolico igual ou acima de $0,5^{\circ} \mathrm{GL}$, ou seja, cervejas e vinhos, para o horário de $21 \mathrm{~h}$ e $6 \mathrm{~h}$. Já entre $21 \mathrm{~h}$ e $23 \mathrm{~h}$, a veiculação só poderá se feita nos intervalos de programas destinados a adultos. Esta mudança recente, ocorrida em dezembro de 2014, entra em vigor 180 dias e deve provocar alterações nas práticas de consumo de cerveja, já que segundo o texto do MPF diversos estudos apontam a influência da publicidade de bebidas no consumo de álcool.

Já em relação aos personagens é importante perceber como os personagens femininos e masculinos são construídos e analisar para quem e a serviço de quem eles são construídos dessa maneira e, mais ainda, a relação entre eles baseada na reafirmação desse espaço masculino heterossexual, branco e jovem, onde as relações de gênero, não são interativas e traduzem a relação de domínio dos homens pelas mulheres.

$\mathrm{O}$ modelo vigente segue sendo do patriarcado, em que as relações de gênero se conformam para o domínio masculino, inclusive em matéria sexual: " O sujeito ativo da relação amorosa é sempre em qualquer caso o homem [...[. A mulher, em relação com seu parceiro, somente tem a possibilidade de rechaçar o que lhe seja previamente ofertado, mas não terá iniciativa na proposição. (LORA, 2008, p. 195, tradução nossa). ${ }^{24}$

Assim, um fala, constrói e sonha nas narrativas e o outro entra como parte desse sonho e cenário, com uma função a cumprir. Para inovar, neste caso, seria preciso que os dois gêneros construíssem as narrativas sem necessariamente um estar submetido à sempre dominar e outro a sempre se oferecer como atrativo ao consumo.

Os estudos culturais, nesta pesquisa, foram primordiais para perceber que os receptores são seres complexos, ativos, criativos e críticos, significam as mensagens de

\footnotetext{
${ }^{24}$ El modelo vigente sigue siendo del patriarcado, em el que las relaciones de pareja se conforman bajo el domínio masculino, incluso em matéria sexual: "El sujeito activo de la relación amorosa es siempre em cualquier caso el hombre [...]. La mujer, em relación com su pareja, solamente tiene la posibilidad de rechazar lo que le sea previamente ofertado, pero no tendrá iniciativa em la proposición. (LORA, 2008, p. 195)
} 
uma maneira diferente da visão amorfa do conceito de massa que comumente são tratados. A complexidade da vida cotidiana produz sentidos variados nos receptores, que negociam a interpretação das mensagens recebidas, acatando, refutando ou ressignificando as mesmas, de acordo com os códigos culturais que possuem.

Por fim, os estudos de recepção são uma troca de aprendizado entre pesquisadores e o mundo, uma aproximação significativa entre teoria e realidade, por mais que possua o limite do específico, dos casos locais, dos grupos comunitários. Para concluir, queremos dizer que esperamos ter contribuído com o desenvolvimento deste tema de pesquisa que para nós se traduz em engajamento e por isso requer uma relação permanente deste tipo de pesquisa, em gênero, entre teoria e prática, para que se aperfeiçoe a investigação voltada para a transformação social, oferecendo elementos que provoquem alguma reflexão para a sociedade. 


\section{Referências}

ALMAPBBDO. www.almapbbdo.com.br. Acesso em 07 de julho de 2013

ALTHUSSER, Louis. A Ideologia e aparelhos ideológicos do Estado. Editorial Presença. 8 ed. 1974.

ALTMAN, Rick. A Theory of Narrative. New York: Columbia University Press, 2008.

AMABILE, Teresa. Creativity in context. New York: Perseus Books, 1996.

AMBEV. Companhia de Bebidas das Américas. Disponível em: www.ambev.com.br. Acesso em: 07 de julho de 2013.

ARAÚJO, Emanuel. A arte da sedução: sexualidade feminina na Colônia. In: DEL PRIORE, Mary (org). História das mulheres no Brasil. 8. ed. São Paulo: Contexto, 2006.

ARRUDA, Angela. Teoria das representações sociais e teorias de gênero. Cad. Pesqui., São Paulo, n. 117, 2002. Disponível em: http://educa.fcc.org.br/pdf/cp/n117/n117a07.pdf. Acesso em: 19 de novembro 2013.

AUGUSTO, Cinara. Quem tem Medo da Propaganda?Estudo da reação à propaganda através da manifestação espontânea do consumidor em Jornal de Santos. São Paulo, 1993. Tese de doutorado - Escola de Comunicação e Artes. Universidade de São Paulo.

AUMONT. Jaques. A imagem. Campinas: Papirus, 2001;

AZEVEDO, Suzana. A Propaganda Institucional como formadora de atitude. Dissertação de Mestrado (Comunicação). PUCRS, 2001.

BACKZO, Bronislaw. A imaginação social. In: Leach, Edmund et Alii. AnthroposHomem. Lisboa: Imprensa Nacional/Casa da Moeda, 1985.

BAKHTIN, Mikhail. A cultura popular na idade média e no Renascimento: o contexto de François Rabelais. São Paulo: Hucitec, 2008.

BARROS, Antonio, DUARTE, Jorge. Métodos e técnicas de pesquisa em comunicação. 2. ed. São Paulo: Atlas, 2006.

BARTHES, Roland. Introdução à análise estrutural da narrativa. In: BARTHES, Roland et al. Análise estrutural da narrativa. Petrópolis: Vozes, 1976.

BAUDRILLARD, Jean. A Sociedade de Consumo. 2 ed. Lisboa: Edições 70, 2008.

BAUER, Martin W. Análise de conteúdo clássica: uma revisão. In: BAUER, Martin W; GASKELL, George (ed). Pesquisa qualitativa com som, imagem e texto. 8. ed. Petrópolis: Vozes, 2010. 
BELELI, Iara. Marcas da diferença na propaganda brasileira. Tese de Doutorado. Universidade Estadual de Campinas, 2005.

BELTING, Hans. Imagem, mídia e corpo. In: Revista de Comunicação, Cultura e Teoria da mídia. N. ${ }^{\circ}$ 08. São Paulo: julho 2008.

BOURDIEU, Pierre. A dominação masculina. 2.ed. Rio de Janeiro: Bertrand Brasil, 2002.

BRAGALIA, Ana Paula. Ética na Propaganda sob o olhar do consumidor e suas significações: um estudo a partir de denúncias encaminhadas ao CONAR. Dissertação de Mestrado (Comunicação). UERJ, 2004.

BRASIL. Ministério da Saúde. Viva: Vigilância de violências e acidentes, 2009.

BRISOLLA, Márcia Regina Santos. Representação da mulher na campanha pela real beleza Dove: um estudo dos processos de significação em imagens publicitárias. Dissertação de mestrado: Artes Visuais/ UFG, 2006.

BRUNO-FARIA, Maria de Fátima. Criatividade, inovação e mudança organizacional. In: LIMA, Suzana Maria Valle. (Org.). Mudança organizacional: teoria e gestão. Rio de Janeiro: FGV, 2003. p. 111-141

BRUNSDON, Charlotte. The Feminist, the Housewife, and the Soap Opera. New York:Oxford University Press, 2000.

A Thief in the night: Stories of feminism in the 1970s at CCCS. In: MORLEY, David \& CHEN, Kuan Hsing. Stuart Hall - Critical dialogues in cultural studies. London/New York: Routledge, p. 276-286, 1996.

. Identity in Feminist Television Criticism In: BRUNSDON, Charlotte; DeAcci, Julie; Lynn Spigel (org). Feminist Television Criticism: A Reader. Oxford: Clarendon Press, 1997, p.114-125.

BUTLER, Judith. Problemas de gênero: feminismo e subversão da identidade. 3. ed. Rio de Janeiro: Civilização Brasileira, , 2010.

CALDAS. Dario (org.). Homens. São Paulo: Editora Senac, 1997.

CAMPOS, Débora Mendes. A figura da mulher na linguagem da propaganda: implicações sociais. Dissertação de mestrado: Sociologia/UFSCar, 2010.

CARRASCOZA, João Anzanello. Do caos à criação publicitária: processo criativo e ready-made na publicidade. São Paulo: Saraiva: 2008.

CARRASCOZA, João Anzanello. Redação publicitária: Estudos sobre a retórica do consumo. 4. ed. São Paulo: Futura, 2003. 
CARVALHO. Nelly de. Publicidade: A linguagem da sedução. 3. ed. São Paulo: Editora Ática, 2002.

CARVALHO, Maria do Perpétuo Socorro Magalhães Freire. A recepção pelos paulistanos das mensagens midiáticas de divulgação do turismo na Bahia. Dissertação de Mestrado (Comunicação e Práticas de Consumo). ESPM, 2009.

CHALHUB, Samira. Funções de linguagem. São Paulo: Editora Ática. 10. ed. 1999.

CLERJAUD, Stephane. La publicidade como ideologia. In: www.philosophiepolitique.net. Acesso em 20 de outubro de 2014.

CONAR, Código de Autorregulamentação Publicitária. Disponível em: www.conar.com.br. Acesso em 10 de junho de 2013.

CONNELL, Raewyn. Masculinities. Cambridge: Polity, 1995.

. The Men and the Boys. Sydney: Allen \& Unwin; Cambridge, Polity Press; Berkeley, University of California Press. 2000.

. Gender. In: World Perspective, Cambridge: Polity, 2009.

MESSERSCHMIDT, James W. Masculinidade hegemônica: repensando o conceito. Estudos Feministas. Florianópolis, n 424, janeiro-abril, 2013.

COSTA, Neusa Meirelles. Seu corpo, esse corpo que é meu... In: LYRA, Bernadette, SANTANA, Gelson (orgs). Corpo e Mídia. São Paulo: Arte e Ciência, 2003.

CSIKSZENNTMIHALYI, Mihaly. Creativity. New York: HarperCollins, 1996.

Implications of a systems perspective for the study of creativity. In: STERNBERG, Robert. J. (Ed.) Handbook of creativity. New York: Cambridge University Press, 2006 [1999]. p. 313-335.

DATASENADO. Violência Doméstica e Familiar contra a Mulher. Senado Federal. Secretaria de Transparência: 2013.

DEL PRIORE, Mary (org). História das mulheres no Brasil. 8. ed. São Paulo: Contexto, 2006.

DELEUZE, Gilles. A imagem-tempo. São Paulo: Brasiliense, [1985] 2007.

DEPEXE, Sandra Dalcul. Publicidade autorreferencial do Diário Gaúcho: encenações do produto midiático e do leitor. Dissertação de Mestrado (Comunicação). UFSM, 2009

DIAS, Fábio Barbosa. Loira gelada, loira gostosa: um estudo de representações imagéticas femininas em peças publicitárias de cerveja. Dissertação de Mestrado: Comunicação/Uel, 2011. 
DIDI - HUBERMAN, Georges. A imagem sobrevivente: História da arte e tempo dos fantasmas segundo Aby Warburg. Tradução Vera Ribeiro. - Rio de Janeiro: contraponto, 2013.

D'INCAO, Maria Ângela. Mulher e família burguesa. In: DEL PRIORE, Mary (org). História das mulheres no Brasil. 8. ed. São Paulo: Contexto, 2006.

DURAND, Gilbert. O imaginário: ensaio acerca das ciências e da filosofia da imagem. Rio de Janeiro: DIFEL, 1998.

ECO, Umberto. James Bond: uma combinatória narrativa In: BARTHES, Roland et al. Análise estrutural da narrativa. Petrópolis: Vozes, 1976.

ELIADE, Mircea. O mito do eterno retorno.São Paulo: Mercuryo, 1992.

ESCOSTEGUY, Ana Carolina. Os estudos culturais. In: HOHFELDT, A. MARTINO, L.C., e FRANÇA, V. V. Teorias da comunicação. Petrópolis, Vozes, 2001

Quando a recepção já não alcança: por uma revisão no objeto e método. In: Grupo de Trabalho "Recepção, Usos e Consumo Midiático", XVII Encontro da Compós, UNIP, São Paulo: 2008.

ESCOSTEGUY, Ana Carolina; JACKS, Nilda. Comunicação e Recepção. São Paulo: Hacker Editores, 2005.

ESTATÍSTICA DE GÊNERO. Uma análise dos resultados do Censo demográfico 2010. IBGE: Rio de janeiro, 2014.

FLATH, Esther e MOSCOVICI, Serge. Social Representation, In: Harré, R. e Lamb, R. (eds.). The Dictionary of Personality and Social Psychology. Londres: Basil Blackwell Publisher, 1983.

FEATHERSTONE, Mike. Cultura de Consumo e pós-modernismo. São Paulo: Studio Nobel, 1995.

FLAUSINO, Márcia Coelho. Narrativas publicitárias: Como a publicidade constrói nosso cotidiano na cultura da mídia. Brasília: Casa das Musas, 2012.

FNAZCA. F/Nazca Saatchi \& Saatchi. www.fnazca.com.br. Acesso em: 07 de julho 2013.

FOCAULT, Michel. História da sexualidade, 3: o cuidado de si. Rio de Janeiro: Edições Graal, 1985.

FOUCAULT, Michel. Microfísica do poder. Rio de Janeiro: Graal, 1992.

FORMIGA SOBRINHO, Asdrúbal Borges. Juventude Consumida: Significação de comerciais sobre jovens e para jovens, Tese de Doutorado: IP/UnB, 2009. 
FORMIGA SOBRINHO, Asdrúbal Borges; GHESTI, Ivânia (orgs.). Personagens da propaganda brasileira: como pessoas e grupos são representados na mídia. Brasília: Universa, 2004.

GALINKIN, Ana Lúcia, SANTOS, Claudiene (orgs.). Gênero e Psicologia Social: interfaces. Brasília: TechnoPolitik, 2010.

GALVÃO, Ivânia Ghesti. Gênero e mídia: tecnologias de produção de subjetividade. In: GALINKIN, Ana Lúcia, SANTOS, Claudiene (orgs.). Gênero e Psicologia Social: interfaces. Brasília: TechnoPolitik, 2010.

GATTI, Bernadete Angelina. Grupo focal na pesquisa em Ciências Sociais e Humanas. Brasília: Líber, 2012.

GAUDREAULT, André, JOST, François. A narrativa cinematográfica. Brasília: Editora da Universidade de Brasília, 2009.

GIL, Antônio Carlos. Métodos e Técnicas de Pesquisa Social. 6. ed. São Paulo: Atlas, 2010 .

GOELLNER, Rene Luiz Vilodre. Publicidade na "Terra do Nunca": as relações entre consumo, juventude e escolha do curso de Publicidade e Propaganda. Tese de Doutorado (Comunicação e Informação). UFRGS, 2007.

GOMES, Itânia Maria Mota. Efeito e Recepção: A interpretação do processo receptivo em duas tradições de investigação sobre os media. Rio de Janeiro: E-papers, 2004.

GONÇALVES, Renata. O pioneirismo de A mulher na sociedade de classes. (Apresentação). In: SAFFIOTI, Heleieth. A mulher na sociedade de classes: Mito e realidade. 3. Ed. São Paulo: Expressão Popular, 2013. p. 11- 24.

GRAY, Ann. Learning from Experience. In: McGUIGAN, Jim (Org.). Cultural Methodologies. London: Sage Publications,1997. p. 87-105.

GUTBIER, Maria Suziane. Mídia e identidade regional: negociações da gauchidade na recepção das propagandas políticas no RS. Dissertação de Mestrado (Comunicação). UNISINOS, 2003.

HALL, S. Encoding/decoding. In: HALL, S. et al. Culture, media, language. London: Routledge, 1992.

O legado teórico dos cultural studies. Revista de comunicação $e$ linguagens, Lisboa, Universidade Nova, 1999, p. 65-81.

HOFF, Tânia. GABRIELLI, Lourdes. Redação Publicitária. 9. ed. Rio de Janeiro: Elsevier, 2004. 
IBGE. Censo Demográfico. 2010.

I LEVANTAMENTO NACIONAL DE PADRÕES DO CONSUMO DE ÁLCOOL. Secretaria Nacional Antidrogas, 2007.

II LEVANTAMENTO NACIONAL DE ÁLCOOL E DROGAS (LENAD), 2012. Ronaldo Laranjeira (Supervisão) [et al.], São Paulo: Instituto Nacional de Ciência e TecnologiA para Políticas de ÁLcool e outras Drogas (INPAD), UNIFESP, 2014.

INTERBRANDSP. www.interbrandsp.com.br. Acesso em 07 de julho de 2012.

IPEA. Trabalho para o mercado e trabalho para casa: persistentes desigualdades de gênero. $\mathrm{N}^{\circ} 149$, maio 2012.

JACKS, Nilda. A publicidade vista pela academia: tendência dos anos 90. In: RAMOS, Roberto (org.). Mídia, textos e contextos. Porto Alegre: PUCRS, 2001. P. 205-219.

. Estudos brasileiros de recepção. Porto Alegre: 2002. Disponível em: http://www.eca.usp.br/associa/alaic/boletim20/nildaj.htm. Acesso em: 20 de novembro de 2013.

JACKS, Nilda; PIEDRAS, Elisa. A recepção da publicidade: um campo incipiente (análise de pesquisas produzidas entre 1990 e 2009). In: TRINDADE, Eneus; PERES, Clotilde (orgs.). I PRÓ-PESQ: Há momentos em que precisamos parar para pensar os rumos da publicidade contemporânea. Salto, SP: Editora Schoba, 2010. (E-book).

JACKS, Nilda, PIEDRAS, Elisa Reinhardt, VILELA, Rosario Sánchez (org.). $O$ que sabemos sobre audiências?: estudos latino-americanos. 1. ed. Porto Alegre: Armazém Digital, 2006.

JACKS, Nilda e ESCOSTEGUY, Ana Carolina. Comunicação e Recepção. São Paulo: Hacker Editores, 2005.

JOHNSON, Robert A. She: a chave do entendimento da psicologia feminina. São Paulo: Mercuryo, 1987.

JUNG. Carl Gustav. Os arquétipos e o inconsciente coletivo. Petrópolis: Editora Vozes, 2000 .

KELLNER, Douglas. A cultura da mídia. São Paulo: EDUSC, 2001.

KESSLER, Janea. Mais do que Feijão com arroz: consumo, publicidade e cultura no meio rural. São Bernardo do Campo, 1997. Dissertação de Mestrado em Comunicação Universidade Metodista de São Paulo.

KUNSH, Margarida Maria Krohling. Planejamento de relações públicas na comunicação integrada. 4. ed. São Paulo: Summus, 2003. 
LARA, Andréa. Representação de mulher nos comerciais de automóveis: garota é apenas equipamento opcional, Dissertação de mestrado: FAC/UnB, 2007.

LAURETIS, Teresa de. A Tecnologia de Gênero. In: Tendências e Impasses: o feminismo como crítica da cultura. HOLLANDA, Heloisa Buarque de (Org.) Rio de janeiro: Rocco, 1994.

LEÓN. José Luis. La actitud mítica em la configuración cultural desde la publicidade. REY. Juan (editor). Publicidad y sociedade: Uma viaje de ida y vuelta. Sevilla: 2008.

LEVYA, Maria José Sánchez; OLAIZOLA, Alicia Reigada. (orgs). Crítica feminista y comunicación. Sevilla: Zamora, 2007.

LIPOVETSKY, Gilles. La era del vacío. 1993

LORA, Manuel Garrido. Redefinición de lo masculino y lo feminino em la publicidade actual. In: REY. Juan (editor). Publicidad y sociedade: Un viaje de ida y vuelta. Sevilla: 2008.

LOPES, Maria Immacolata Vassalo de. Pesquisa em Comunicação: formulação de um modelo metodológico. 6. ed. São Paulo: Loyola, 2001.

LOURO, Guacira Lopes. Gênero, sexualidade e educação - Uma perspectiva pósestruturalista. 2 ed. Petrópolis: Vozes/CNTE, 1997.

LUBART, Todd. Psicologia da Criatividade.Porto Alegre: Artmed, 2007.

Creativity across cultures. In: STERNBERG, Robert. J. (Ed.) Handbook of creativity. New York: Cambridge University Press, 2006 [1999]. p. 339350 .

MACHADO. Liliane Maria Macedo. E a mídia criou a mulher: como a TV e o cinema constroem o sistema de sexo / gênero. Tese de Doutorado. PPGH/ UnB. 2006.

MALDANER, Nilse Maria. Os jovens e a recepção da publicidade televisiva. Dissertação de Mestrado (Comunicação). UMESP, 2000.

MAPA DA VIOLÊNCIA. Caderno Complementar 1: Homicídio de Mulheres no Brasil. 2012.

MARTÍN-BARBERO, Jesús. Dos meios às mediações: comunicação, cultura e hegemonia. Rio de Janeiro: Editora UFRJ, 1997.

- Ofício de Cartógrafo: Travessias latino-americanas da comunicação na cultura. São Paulo: Edições Loyola, 2004.

MATOS, Rita de Cassia Aragão de. A orgia dos objetos. estudos sobre recepção, publicidade e "excluídos". Dissertação de Mestrado em Comunicação. Universidade 
Federal da Bahia, 1995.

MATTELART, Michèle. Mujeres y medios:. Memorias de un pensamento crítico. In: LEVYA, Maria José Sánchez; OLAIZOLA, Alicia Reigada. (orgs). Crítica feminista y comunicación. Sevilla: Zamora, 2007.

MCLUHAN, Marshall. Os meios de comunicação como extensões do homem. 4. ed. São Paulo: Editora Cultrix, 1974.

McROBBIE, Angela. More!: nuevas sexualidades em las revistas para chicas y mujeres. In: CURRAN, J.; MORLEY, D.; WALKERDINE, V. (Org) Estudios culturales y comunicación: Análisis, producción y consume cultural de las políticas de identidad y el posmodernismo. Barcelona, Buenos Aires, México: Paidós, 1998. p.253-296.

MEMÓRIA DA PROPAGANDA. www.memoriadapropaganda.org.br. Acesso em 07 de julho de 2013.

MESSA, Márcia Rejane. Os estudos feministas de mídia: uma trajetória angloamericana. In: Revista Cartografias. Famecos: julho 2006.

MICHAUD, Philippe - Alain. Aby Warburg e a imagem em movimento. Tradução Vera Ribeiro. - Rio de Janeiro: contraponto, 2013.

MILITO. Caio Anawate Kuri. Culto ao corpo na publicidade: novas tecnologias para construção do eu. Dissertação de mestrado: Universidade Estadual Paulista,Instituto de Biociências de Rio Claro, 2012.

MODLESKI, Tania. The search of Tomorrow in Today's Soap Operas. In: BRUNSDON, Charlotte; DeeAcci, Julie; Lynn Spigel (org). Feminist Television Criticism: A Reader. Oxford: Clarendon Press, 1997, p. 36-47.

MORENO. Rachel. A imagem da mulher na mídia: controle social comparado. São Paulo: Publisher Brasil, 2012.

MORIN, Edgar. Cultura de Massas no Século XX: o espírito do tempo. Rio de Janeiro: Forense, 1969.

MORIN, Edgar. A cabeça bem-feita: repensar a reforma, reformar o pensamento. Trad. Eloá Jacobina. $7^{a}$ edição, Rio de Janeiro: Bertrand Brasil, 2002, 128 p.

MORIN, Edgar. A religação dos saberes: o desafio do século XXI. Trad. Flávia Nascimento. $3^{\text {a }}$ edição, Rio de Janeiro: Bertrand Brasil, 2002, 588 p.

MORIN, Edgar. O método 5: a humanidade da humanidade. $2^{\text {a }}$ edição, Trad. Juremir Machado da Silva. Porto Alegre: Sulina, 2003, 312 p.

MORIN, Edgar. O enigma do homem: para uma nova antropologia. Trad. Fernando de Castro Ferro. Rio de Janeiro: Zahar Editores, 1979, 227 p. 
MORIN, Edgar. Os sete saberes necessários à educação do futuro. Trad. Catarina Eleonora F.da Silva e Jeanne Sawaya, $8^{a}$ edição, São Paulo: Cortez; Brasília: Unesco, 2003, 118 p.

MORIN, Edgar. Para sair do século XX. Trad. Vera Azambuja Harvey. Rio de Janeiro: Nova Fronteira, 1986, 361 p.

MOTTA, Luiz Gonzaga. Análise Crítica da Narrativa. No prelo.

NOBRE, Mirian, FARIA, Nalu. Gênero e desigualdade. Cadernos Sempreviva. São Paulo, SOF- Sempreviva Organização Feminista, 1997.

NOLASCO, Sócrates. Um "homem de verdade".In: CALDAS. Dario (org.). Homens. São Paulo: Editora Senac, 1997.

PATARA, Luciana. Comunicação publicitária criativa: um estudo da recepção sobre a peça "A Semana" feita para a revista Época. Dissertação de Mestrado (Comunicação). UNIP, 2008.

PERROT, Michelle. Os silêncios do corpo da mulher. In: MATOS, M. I. S.; SOIHET, R. (Org.). O corpo feminino em debate. São Paulo: UNESP, 2003. p. 13-27.

PIEDRAS, Elisa Reinhardt. Fluxo publicitário: Anúncios, produtores e receptores. Porto Alegre: Ed. Saraiva, 2009.

Publicidade, imaginário e consumo: anúncios no cotidiano feminino. Tese de Doutorado (Comunicação e Informação). PUCRS, 2007.

PINEDA, Antonio. El individualismo como ideologema del discurso publicitário. In: REY. Juan (editor). Publicidad y sociedade: Uma viaje de ida y vuelta. Sevilla: 2008.

PIRES, Monique Vidal. Mulheres em profusão: imagens das mulheres na propaganda impressa brasileira (1957 - 1997). Dissertação de mestrado: PPGH/ UnB, 2007.

PLATÃO. O banquete. São Paulo: Nova Cultural, 1987.[Coleção Os pensadores]

RADWAY, Janice. Reading the Romance: Women, Patriarchy and Popular Literature. In: BROOKER, Will; JERMYN, Deborah (org). The Audience Studies Reader. London/New York: Routledge, 2003, p. 219-225.

RAMOS, Krishna, Sedução e desejo - representação da mulher nos anúncios de perfumes femininos, Dissertação de mestrado: FAC/UnB, 2006.

REY. Juan (editor). Publicidad y sociedade: Uma viaje de ida y vuelta. Sevilla: 2008.

ROBLES, Marta. Mulheres, mitos e deusas: o feminino através dos tempos.São Paulo: Aleph, 2006. 
ROCHA, Everardo P. Guimarães. Magia e Capitalismo: um estudo antropológico da publicidade. 3.ed. São Paulo: Brasiliense, 1995.

ROCHA, Everardo. Representações do consumo: estudos sobre a narrativa publicitária. Rio de Janeiro: Mauad, 2006.

RAMINELLI, Ronald. Eva Tupinambá. In: DEL PRIORE, Mary (org). História das mulheres no Brasil. 8. ed. São Paulo: Contexto, 2006.

SARTRE. Jean-Paul. $O$ imaginário: Psicologia fenomenológica da imaginação. São Paulo: Editora Ática. 1996.

SAFFIOTI, Heleieth I. B. O poder do macho. São Paulo: Moderna, 1987.

SAFFIOTI, Heleieth Iara Bongiovani. Gênero, patriarcado, violência. São Paulo: editora Perseu Abramo, 2004.

. A mulher na sociedade de classes: Mito e realidade. 3. Ed. São Paulo: Expressão Popular, 2013.

SANTAELLA, Lucia. Comunicação e Pesquisa: projetos para mestrado e doutorado. São Paulo: Hacker Editores, 2001.

SANTOR, Fernando Silva. A estratégia publicitária influenciada pelas lógicas de consumo. Dissertação de Mestrado (Comunicação).UFSM, 2009.

SANTOS, Filipe Bordinhão. Masculinidade em anúncios: recepção publicitária e identidade de gênero. Dissertação de Mestrado (Comunicação). UFSM, 2012.

SCOTT, Joan. Gênero: uma categoria útil de análise histórica. In: Educação $e$ Realidade. v. 16, n. 2, 1990. p. 5-22.

SCOTT, Joan. Gênero: uma categoria útil de análise histórica. In: Educação e Realidade, Porto Alegre, vol. 20, n. 2, p.71-99, jul/dez. 1995.

SHAW, Inês Senna. O corpo feminino na propaganda. In: LYRA, Bernadette, SANTANA, Gelson (orgs). Corpo e Mídia. São Paulo: Arte e Ciência, 2003.

SILVA, Denise Teresinha da. Mulher e publicidade: estudo da produção e da recepção da identidade da Mulher-Mãe na mídia televisiva. Dissertação de Mestrado (Comunicação). Unisinos, 2002.

SILVEIRA, Beatriz Silveira. O consumo da magreza: A publicidade como ideal da felicidade. Dissertação de mestrado: PPGCOM/UnB, 2013.

SIMÕES, Júlia. Para que serve a mulher do anúncio? Um estudo sobre representações de gênero nas imagens publicitárias, Dissertação de mestrado: UNB, 2013.

SIQUEIRA, Mauro Henrique. Marginal ou invisível? A representação de usuários de 
drogas injetáveis nas publicidades do Ministério da Saúde. Dissertação de Mestrado (Comunicação). UnB, 2004.

SKOL. www.skol.com.br. Acesso em 07 de julho de 2013

SOUZA. Sandra Maria Ribeiro de. A propósito de consumo, censura, cerveja e celebridade: a construção de sentido da marca Devassa. In: Matrizes. Ano 5, $\mathrm{n}^{\circ} 1$. São Paulo: ECA/USP: 2011.

TODOROV, Tzvetan. As categorias da narrativa literária. In: BARTHES, Roland et al. Análise estrutural da narrativa. Petrópolis: Vozes, 1976.

TRINDADE, Eneus. A regulação na publicidade de cervejas junto ao público adolescente: problemáticas e caminhos da pesquisa comunicacional. Revista Signos do Consumo, v. 4, $\mathrm{n}^{\circ} \quad 2,2012$ p. 214-236. Disponível em: http://www.revistas.usp.br/signosdoconsumo/article/view/50874.

TRIVINOS, A. N. S. Introdução à pesquisa em ciências sociais: a pesquisa qualitativa em educação. São Paulo: Atlas, 1987.

VAZ, Natalia de Alcantara. Discurso publicitário como dispositivo disciplinar: os impactos da campanha "Real Universitário" na recepção do público jovem. Dissertação de Mestrado (Comunicação e Práticas de Consumo). ESPM, 2008.

VENTURI, Gustavo; RECAMÁN, Marisol; OLIVEIRA, Suely de (orgs.). A mulher brasileira nos espaços público e privado. São Paulo: Editora Perseu Abramo, 2004.

VIGARELLO, G. História da beleza: o corpo e a arte de se embelezar do renascimento aos dias de hoje. Rio de Janeiro: Ediouro, 2006.

VINIC, Richard. O estímulo audiovisual na comunicação publicitária da marca Havaianas: um estudo da recepção a partir da diferenciação dos gêneros. Dissertação de Mestrado (Comunicação). UNIP, 2008.

WARBURG. Aby. A renovação da antiguidade pagã: Contribuições científico culturais para a história do renascimento europeu. Tradução Markus Hediger. - Rio de Janeiro: contraponto, 2013.

ZAMBONI, Júlia Simões. Para que serve a mulher do anúncio? Um estudo sobre representações de gênero nas imagens publicitárias, Dissertação de mestrado: PPGCOM/UnB, 2013.

ZOONEN, Liesbet van. Feminist Media Studies. London: Sage Publications, 1996. 


\section{Anexos}

\section{PERGUNTAS NORTEADORAS HÁBITOS DE MÍDIA}

Nome:

Idade:

Profissão:

Qual é o meio de comunicação mais importante para você?

A qual dele você dedica sua atenção?

Porquê?

Com que frequência você vai ao cinema?

Quanto tempo você passa assistindo TV, diariamente?

Em que horário você mais assiste?

TV aberta ou a cabo?

Cite algum comercial de TV que você lembre ou tenha gostado ou não tenha gostado, mas que de alguma maneira marcou.

Você lembra de algum comercial de cerveja? 


\section{ROTEIRO GRUPO FOCAL}

1- O que mais chamou a atenção de vocês nestas peças publicitárias?

2- Como a mulher é apresentada nelas?

3- Vocês as consideram como sedutoras nas peças?

4- $\quad$ O que caracteriza tal sedução?

5- $\quad$ O que você acham que contribui para que ela seja colocada desta maneira?

6- $\quad$ As situações apresentadas nestas peças publicitárias acontece na vida real?

7- Como os homens são apresentados?

8- Vocês os consideram como bobos nas peças?

9- Que semelhanças e diferenças vocês veem entre a forma que a mulher aparece e o homem?

10- Como as relações de gênero estão representadas em todos eles?

11- Estas publicidades sugerem como homens e mulheres devem se comportar/ conversar ao consumir cerveja nas situações apresentadas?

12- Vocês se sentem influenciadas por elas?

13- Porquê?

14- Vocês acham que os comerciais estão direcionados para que público? Por quê?

15- $\quad$ O que deveria mudar nos personagens para que vocês mudassem de opinião sobre os comerciais?

16- E o que deveria mudar na história/ narrativa para que vocês mudassem de opinião sobre os comerciais?

17- O que vocês acham que os homens vêem estes comerciais?

18- Vocês acham que os homens reais gostam da forma como eles são apresentados nestas peças?

19- Vocês acham que os homens reais gostam da forma como as mulheres são apresentadas nestas peças?

20- O que você acha que desce redondo? 